ORNL/TM-2001/193

TTP: OR1-8-SS-41

\title{
PERFORMANCE EVALUATION OF IN-SITU IRON REACTIVE BARRIERS AT THE OAK RIDGE Y-12 SITE
}

FY2000-Milestone Report

Subsurface Contaminants Focus Area

Metals and Radionuclides Product Line 


\section{DOCUMENT AVAILABILITY}

Reports produced after January 1, 1996, are generally available free via the U.S. Department of Energy (DOE) Information Bridge.

Web site http://www.osti.gov/bridge

Reports produced before January 1, 1996, may be purchased by members of the public from the following source.

National Technical Information Service

5285 Port Royal Road

Springfield, VA 22161

Telephone 703-605-6000 (1-800-553-6847)

TDD 703-487-4639

Fax 703-605-6900

E-mail info@ntis.fedworld.gov

Web site http://www.ntis.gov/support/ordernowabout.htm

Reports are available to DOE employees, DOE contractors, Energy Technology Data Exchange (ETDE) representatives, and International Nuclear Information System (INIS) representatives from the following source.

Office of Scientific and Technical Information

P.O. Box 62

Oak Ridge, TN 37831

Telephone 865-576-8401

Fax 865-576-5728

E-mail reports@adonis.osti.gov

Web site http://www.osti.gov/contact.html

This report was prepared as an account of work sponsored by an agency of the United States Government. Neither the United States Government nor any agency thereof, nor any of their employees, makes any warranty, express or implied, or assumes any legal liability or responsibility for the accuracy, completeness, or usefulness of any information, apparatus, product or process disclosed, or represents that its use would not infringe privately owned rights. Reference herein to any specific commercial product, process, or service by trade name, trademark, manufacturer, or otherwise, does not necessarily constitute or imply its endorsement, recommendation, or favoring by the United States Government or any agency thereof. The views and opinions of authors expressed herein do not necessarily state or reflect those of the United States Government or any agency thereof. 
ORNL/TM-2001/193

TTP: OR1-8-SS-41

Environmental Sciences Division

FY 2000-Milestone Report

PERFORMANCE EVALUATION

OF IN-SITU IRON REACTIVE BARRIERS AT THE

OAK RIDGE Y-12 SITE

D. B. Watson, D. H. Phillips, Baohua Gu

Environmental Sciences Division

Oak Ridge National Laboratory

Date Published: March 2002

Prepared for

U.S. Department of Energy

Office of Biological and Environmental Research

Budget Activity Number: KP 1301010

Prepared by

OAK RIDGE NATIONAL LABORATORY

Oak Ridge, Tennessee 37831

managed by

UT-BATTELLE, LLC

for the

U.S. DEPARTMENT OF ENERGY

under contract DE-AC05-00OR22725 



\section{CONTENTS}

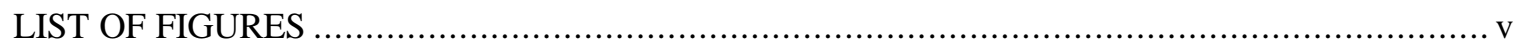

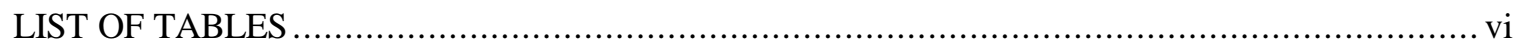

ACRONYMS

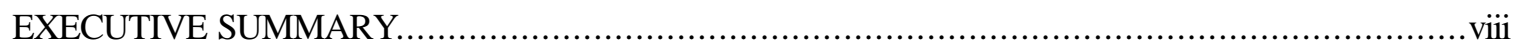

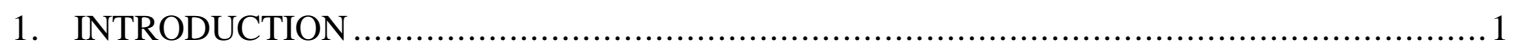

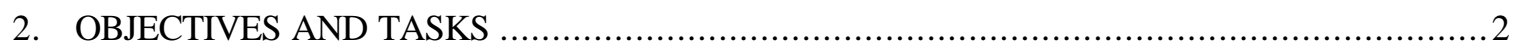

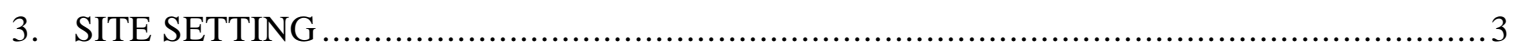

3.1 S-3 PONDS GEOCHEMICAL AND HYDROGEOLOGIC SETTING $\ldots \ldots \ldots \ldots \ldots \ldots \ldots \ldots \ldots$

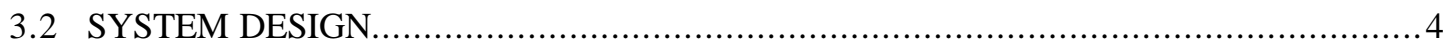

4. URANIUM REMOVAL BY SYNTHETIC RESINS (PAT HWAY 1) ….............................

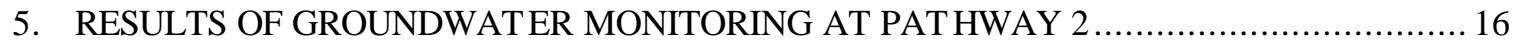

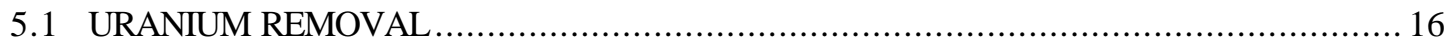

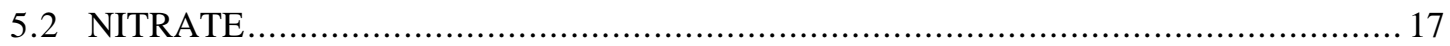

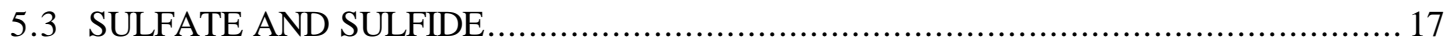

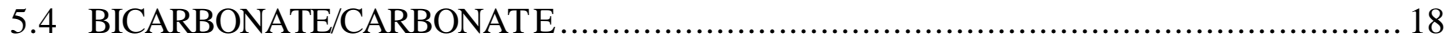

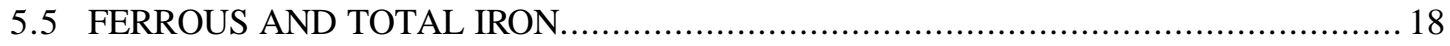

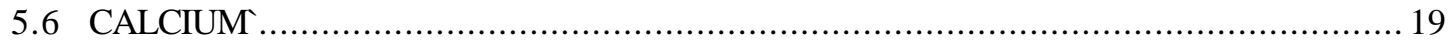

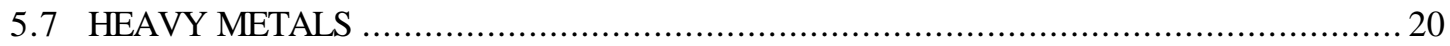

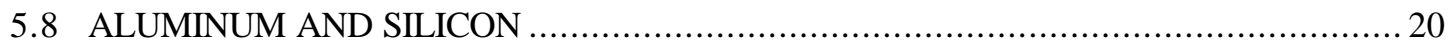

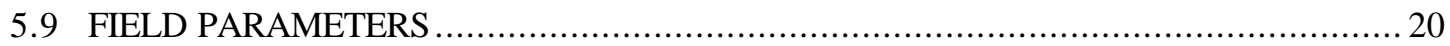

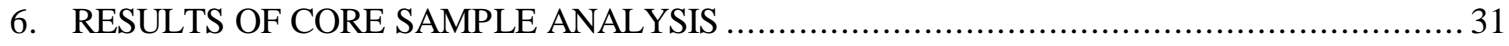

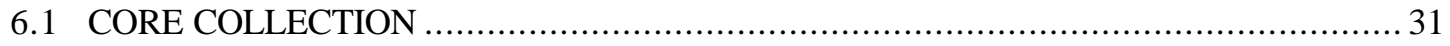

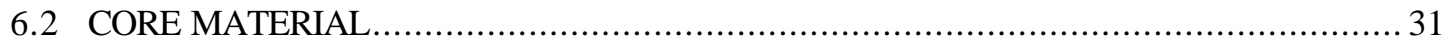

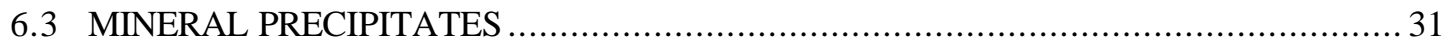

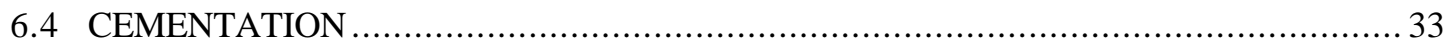

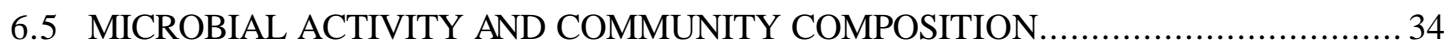

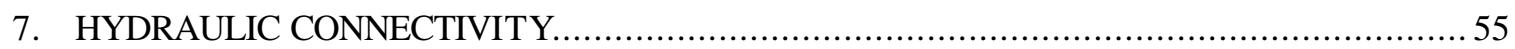

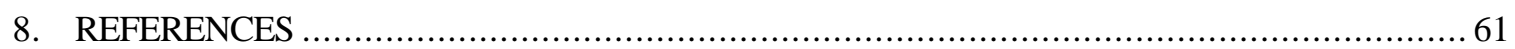

APPENDIX A ANALYTICAL DATA

KPA ANALYSIS OF TOTAL URANIUM (U) ….......................................... TABLE A1

IC ANALYSIS OF NITRATE $\left(\mathrm{NO}_{3}\right)$ IN GROUNDWATER …........................ TABLE A2

IC ANALYSIS OF SULFATE $\left(\mathrm{SO}_{4}\right)$ IN GROUNDWATER …........................... TABLE A3

IC ANALYSIS OF BICARBONATE $\left(\mathrm{HCO}_{3}\right)$ IN GROUNDWATER .................... TABLE A4

FIELD PARAMETERS FROM GROUNDWATER FROM PATHWAY $2 \ldots \ldots \ldots \ldots \ldots . . .$. TABLE A5

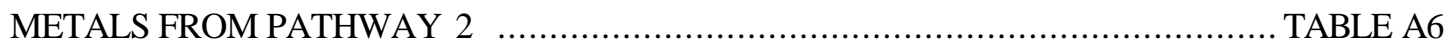

IC ANALYSIS OF CHLORIDE (CL-) IN GROUNDWATER .............................. TABLE A7

APPENDIX B GROUNDWATER LEVEL DATA

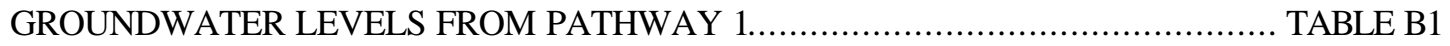

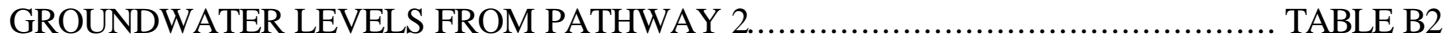




\section{LIST OF FIGURES}

Figure

Figure 3.1 Location of Oak Ridge Y-12 Bear Creek Valley S-3 Ponds Area ........................................................6

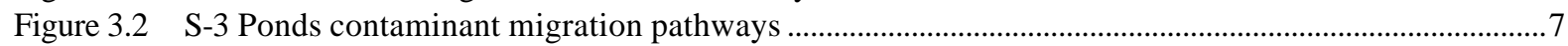

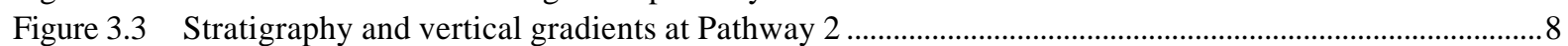

Figure 4.1 Removal of uranium from high ionic strength groundwater by synthetic resins $(100 \mathrm{~mL})$..................14

Figure 4.2 Removal of uranium from high ionic strength groundwater from Y-12 (original conc. U 4.7 mg/L) spiked with $~ 20 \mathrm{mg} / \mathrm{L}$ U by synthetic resin.................................................................................. 15

Figure 5.1 Monitoring locations at Pathway 2 Permeable Reactive Barrier...........................................................22

Figure 5.2 Uranium concentration profiles in some selected monitoring wells or piezometers within and in vicinity of the $\mathrm{Fe}^{0}$ reactive barrier at the Oak Ridge Y-12 site............................................................23

Figure 5.3 Nitrate concentration profiles in some selected monitoring wells or piezometers within and in vicinity of the $\mathrm{Fe}^{0}$ reactive barrier at the Oak Ridge Y-12 site. ...........................................................................24

Figure 5.4 Sulfate concentration in some selected monitoring wells or piezometers within and in vicinity of the $\mathrm{Fe}^{0}$ reactive barrier at the Oak Ridge Y-12 site......

Figure 5.5 Carbonate/bicarbonate concentration in some selected monitoring wells or piezometers within and in vicinity of the $\mathrm{Fe}^{0}$ reactive barrier at the Oak Ridge Y-12 site ...............................................................26

Figure 5.6 Ferrous ion concentration in some selected monitoring wells or piezometers within and in vicinity of

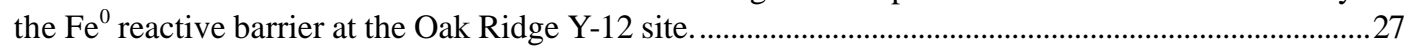

Figure 5.7 Calcium concentration in some selected monitoring wells or piezometers within and in vicinity of the $\mathrm{Fe}^{0}$ reactive barrier at the Oak Ridge Y-12 site.

Figure 5.8 Groundwater $\mathrm{pH}$ in some selected monitoring wells or piezometers within and in vicinity of the Fe reactive barrier at the Oak Ridge Y-12 site ......................................................................................2

Figure 5.9 Groundwater Eh in some selected monitoring wells or piezometers within and in vicinity of the $\mathrm{Fe}^{0}$

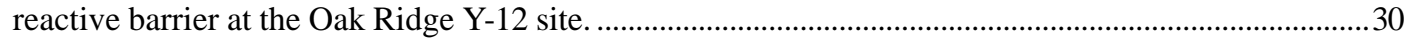

Figure 6.1 The core drill at a $60^{\circ}$ angle and a core in a polyurethane tube...............................................................36

Figure 6.2 Location of cores colected at Pathway 2 trench June 2000 ................................................................37

Figure 6.3 A portion of the core and coring tube showing the diameter of the core, and the clean break at the interface between the coring material and soil/fill material in a core.......................................................38

Figure 6.4 X-ray diffractograms of the shallow portion of the $\mathrm{Fe}^{0}$ material from Fan 1.........................................39

Figure 6.5 X-ray diffractograms of the deep portion of the $\mathrm{Fe}^{0}$ material from Fan 1..............................................40

Figure 6.6 X-ray diffractograms of the shallow portion of the $\mathrm{Fe}^{0}$ material from Fan 2........................................4

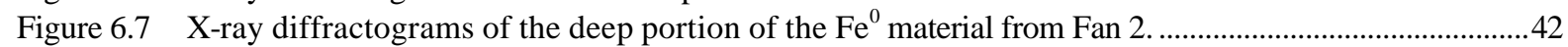

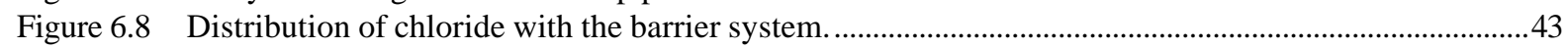

Figure 6.9 Distribution of chloride within the $\mathrm{Fe}^{0}$ of the barrier.......................................................................44

Figure 6.10 Photomicrograph of geothite $(\alpha-\mathrm{FeOOH})$ and aragonite $\left(\mathrm{CaCO}_{3}\right)$ in shallow Fan 1 at $19-20 \mathrm{ft}$, SEM-

EDX of an area of the geothite, and SED-EDX of an area of the aragonite. .......................................45

Figure 6.11 Photomicrographs of green rusts from the barrier............................................................................

Figure 6.12 Photomicrographs of amorphous FeS in the barrier. .......................................................................47

Figure 6.13 Photomicrographs of crystalline FeS from the barrier.....................................................................48

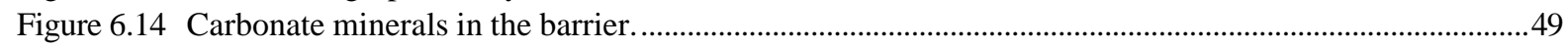

Figure 6.15 Core material from shallow Fan 1 showing cementation.........................................................................50

Figure 6.16 Biomass content (picomoles PLFA/g) in groundwater samples........................................................51

Figure 6.17 A comparison of the relative percentages of total PLFA structural groups in groundwater samples.52

Figure 6.18 Biomass content (picomoles PLFA/g) in soil and iron core samples......................................................53

Figure 6.19 A comparison of the relative percentages of total PLFA structural groups in the soil and iron core

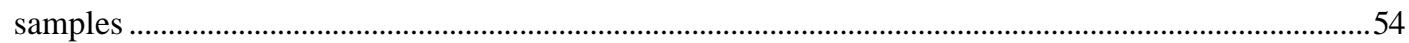

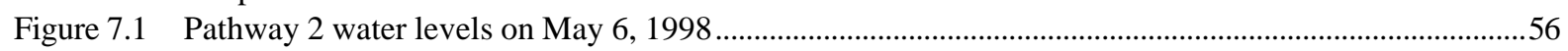

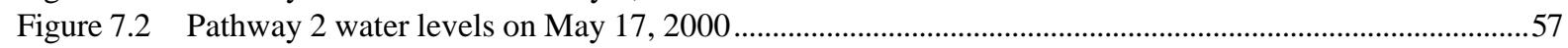

Figure 7.3 Groundwater elevation and gradients across the iron in the Pathway 2 trench..................................58

Figure 7.4 Pathway 2 groundwater elevations (manual) ....................................................................................59 


\section{LIST OF TABLES}

Table

Page

Table 4-1 General properties of selected resins used in the batch tests.. 10

Table 4-2 Distribution coefficients $(\mathrm{Kd})(\mathrm{mL} \mathrm{g}-1)$ of U on resins - groundwater from PTMW2 (15 $\mathrm{mL}$ test).

Table 4-3 Distribution coefficients $(\mathrm{Kd})(\mathrm{mL} \mathrm{g}-1)$ of $\mathrm{U}$ on resins - groundwater from PTMW2

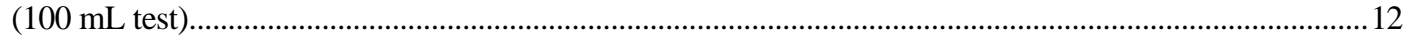

Table 4-4 Distribution coefficients $(\mathrm{Kd})(\mathrm{mL} \mathrm{g}-1)$ of $\mathrm{U}$ on resins from simulated groundwater..........................13 


\section{ACRONYMS}

CERCLA Comprehensive Environmental Restoration, Compensation, and Liability Act

$\mathrm{BCV}$

DO

DOE Bear Creek Valley

dissolved oxygen

EDX

Department of Energy

$\mathrm{EM}$

$\mathrm{Fe}^{0}$

ORP

PCE

PORTS

SEM

VOC

Engineering Evaluation/Cost Analysis

Environmental Management

zero valent iron

low redox potential

tetrachloroethylene

Portsmouth Gaseous Diffusion Plant

$\mathrm{VOC}$

scanning electron microscope

volatile organic chemicals

$\mathrm{x}$-ray diffraction 


\section{EXECUTIVE SUMMARY}

In November 1997, a permeable iron reactive barrier trench was installed at the S-3 Ponds Pathway 2 Site located at the Y-12 Plant, Oak Ridge, Tennessee. The overall goal of the project is to evaluate the ability of permeable reactive barrier technology to remove uranium, nitrate, and other inorganic contaminants in groundwater and to assess impacts of biogeochemical interactions on long-term performance of the treatment system. Zero-valent iron $\left(\mathrm{Fe}^{0}\right)$ was used as the reactive medium, which creates a localized zone of reduction or low oxidation reduction potential (ORP), elevated $\mathrm{pH}$, and dissolved $\mathrm{H}_{2}$ as $\mathrm{Fe}^{0}$ corrodes in groundwater. These conditions favor the removal of metals and radionuclides (such as uranium and technetium) through redox-driven precipitation and/or sorption to iron corrosion byproducts, such as iron oxyhydroxides. The technology is anticipated to be economical and low in maintenance as compared with conventional pump-andtreat technology.

Groundwater monitoring results indicate that the iron barrier is effectively removing uranium and technetium, the primary contaminants of concern, as anticipated from our previous laboratory studies. In addition to uranium and technetium, nitrate, sulfate, bicarbonate, calcium, and magnesium are also found to be removed, either partially or completely by the iron barrier. Elevated concentrations of ferrous ions and sulfide, and $\mathrm{pH}$ were observed within the iron barrier. Although ferrous iron concentrations were initially very high after barrier installation, ferrous ion concentrations have decreased to low to non-detectable levels as the $\mathrm{pH}$ within the iron has increased over time (as high as 9 or 10).

Iron and soil core samples were taken in February 1999 and May 2000 in order to evaluate the iron surface passivation, morphology, mineral precipitation and cementation, and microbial activity within and in the vicinity of the iron barrier. Results indicate that most of the iron filings collected in cores were still loose and not clogged after approximately 2.5 years of barrier installation. However, significant amounts of cemented iron filings were observed in the upgradient portion of the iron. In particular, the cementation appeared to have increased significantly over time from the 1999 to 2000 coring events in both the upgradient and downgradient portions of the iron. Minerals identified by scanning electron microscope (SEM), energy dispersive $\mathrm{x}$-ray (EDX), and $\mathrm{x}$-ray diffraction (XRD) that have precipitated in the iron include iron sulfide, calcium carbonate (aragonite), iron oxyhydroxides (goethite, akagneite, amorphous), siderite (iron carbonate), makinawite, and green rusts. These mineral precipitants are responsible for the cementation observed within the iron barrier. Elevated microbial activity and increased diversity within and in the vicinity of the iron barrier were also observed, particularly denitrifiers and sulfate-reducers, which may have been responsible or partially responsible for the removal of nitrate and sulfate in groundwater and the formation of ferrous sulfide minerals within the iron barrier.

Hydraulic gradients across the Pathway 2 site have remained relatively stable and consistent from east to west. Increases and decreases in the gradients across the site observed over the past 2.5 years appear to be primarily related to recharge during precipitation events and seasonal fluctuations. However, closer inspection of gradient fluctuations within the iron appear to indicate that cementation within the iron may be starting to impact groundwater flow through the iron. Since the spring of 1999, recharge events have had a more pronounced impact on hydraulic gradients observed between wells located upgradient, within, and downgradient of the iron. This data suggests that the connectivity of the iron and gravel in the upgradient portion of the trench to the iron and gravel in the downgradient portion of the trench may be decreasing over time due to cementation in the iron. 


\section{INTRODUCTION}

In situ permeable reactive barrier technology (based primarily on zero-valence iron, $\mathrm{Fe}^{0}$ ) has been identified as a potentially cost-effective, passive treatment technology for contaminated groundwater (Gillham and O'Hannesin, 1992). Interest in the technology from both private industries and federal agencies generated extensive research activities from laboratory studies to field implementation in the last few years. Over a dozen reactive barriers have been installed across North America, although most of these are used for the treatment of chlorinated organic solvents using zero-valent iron $\left(\mathrm{Fe}^{0}\right)\left(\mathrm{O}^{\prime}\right.$ Hannesin, 1993; Puls et al., 1995; Shoemaker et al., 1995; Gu et al., 1998; Gu et al., 1999; Watson et al., 1999). Only limited information has been available with respect to the long-term performance and the enduring treatment efficiency of these reactive barriers. For example, existing data on influent and effluent water chemistry have been limited. In the study at Hill AFB, pH was observed to increase from 7.5 to greater than 9 in the effluent. High $\mathrm{pH}$ and low dissolved lxygen (D.O.) was also observed downgradient in the installation at Sunnyvale, CA site. However, at Portsmouth Gaseous Diffusion Plant, OH (PORTS) and Elizabeth City, NC sites, pH increased in the effluent, but remained close to the neutral pH. (Powell et al., 1995; Liang et al., 1997).

Limited core samples of iron or soil have been collected to assess precipitation by x-ray diffraction and scanning electron microscopy (Shoemaker et al, 1995). The results have also been inconsistent. Core samples collected from iron media after one year of operation at the Borden site for biological studies, indicated no evidence of chemical precipitation and microbial activity or alteration of the iron (Matheson, 1994). On the contrary, precipitate formation was observed at the top of the reactor at New Jersey site, and gradual plugging of canisters occurred at Hill AFB and PORTS, as evidenced by pressure drop across the treatment systems. At Hill AFB, iron and calcium carbonates were observed, and significant corrosion of iron filings were also reported during a field pilot-scale experiment using zero-valence iron to remove chlorinated organic compounds at the Portsmouth Gaseous Diffusion Plant, OH (Liang et al, 1997). Apparently, further development and long-term performance evaluation of reactive barriers are needed to increase the comfort level of the remediation community and regulators (Shoemaker et al., 1995). Short-term evaluation of a few pilot- and field-scale installations have shown that the target contaminants are effectively removed by $\mathrm{Fe}^{0}$ at a much lower cost than pump-and-treat technology, thus demonstrating that the passive, permeable reactive barrier technology provides a viable solution to groundwater contamination problems. However, systematic studies and long-term performance evaluations are underway but have not been completed to address the potential clogging and alteration to surface reactivity by surface mineral precipitation and biological activities, particularly with groundwater containing high salts and mixed contaminants as often observed at many Department of Energy (DOE) sites like the Y-12 Plant Site. (Gu et al., 1998; Gu et al., 1999; Watson et al., 1999).

This DOE EM-50 (Environmental Management) funded project is a collaborative effort with a DOE EM40 treatability study project that was initiated in FY 96. Preliminary tests in FY 96 were performed with several potential barrier materials (e.g., zero-valence iron filings, peat moss, metal oxides, zeolite, and synthetic resins). In FY 97, both laboratory mechanistic studies to enhance the media treatment efficiencies (supported by EM-50) and field column tests (supported by EM-40) were conducted for the treatment of a suite of inorganic and organic contaminants at the Bear Creek Valley (BCV) site. Treatment systems for S-3 Ponds Pathway 1 and 2 were designed in 1997. In FY 98, the funnel and gate was installed at Pathway 1 and the permeable reactive trench was installed at Pathway 2. Preliminary performance evaluation of the Pathway 2 permeable reactive trench and construction of the Pathway 1 removable treatment trains were also conducted in 1998. Therefore, the FY 98 work has set the stage for performance evaluation of these two reactive barriers and their physical and hydraulic characteristics in FY 99 and FY 00. 


\section{OBJECTIVES AND TASKS}

This project is designed to meet the goal of DOE EM for the deployment of in situ reactive barriers (primarily zero-valence iron-based barriers) with applied research to monitor, evaluate, and predict the longterm performance of the barriers. Additionally, this project will provide information on mitigating deleterious effects from complex geochemical and microbial reactions, and perhaps take advantage of system characteristics to improve the sequestering of radionuclides and metals and the degradation of organics. This information will allow specifications for use of barriers at other sites to be developed a priori rather than waiting to see what happens in the field. Specific objectives of the project for FY 00 were:

1. Evaluate the treatment efficiency of some specific ion-exchange resins to remove uranium in groundwater at Pathway 1 and 3, where groundwater is characterized with a low $\mathrm{pH}$ and high ionic strength.

2. Continue to evaluate the treatment efficiency, sequestration of uranium and other inorganic contaminants, and byproduct formation of the iron filings installed in situ at the Pathway 2 permeable reactive trench.

3. Evaluate physical, chemical, and biological effects on the long-term performance (e.g., clogging and reactivity) of the Pathway 2 passive treatment systems.

4. Evaluate and contrast the hydraulic capture performance of the permeable reactive barrier at the Pathway 2 site.

The following tasks were conducted in FY 00:

1. Laboratory evaluation of specific ion-exchange resins to remove uranium using both simulated groundwater representative of Pathway 2 and site groundwater from well PTMW2 which is representative of groundwater from Pathway 1 and 3(i.e., with a low $\mathrm{pH}$ and high nitrate and bicarbonate concentrations).

2. Sampling groundwater and surface water quarterly to monitor geochemical conditions in and around the reactive media.

3. Analyses of water samples for field parameters, anions, metal cations and uranium.

4. Monitoring groundwater levels manually and with pressure transducers and data loggers.

5. Collecting cores from the trench in June 2000 and conducting autopsies on the reactive media to assess the impact of mineral precipitation and the deterioration of iron reactive media.

6. Analysis of groundwater and core samples for microbial activity and community structure using PLFA and DGGE analyses.

This project addresses Work Package D, "Innovative In-Situ Chemical Treatment of Metals/Rads," in the Subsurface Contamination Focus Area guidance. Data gathered from these two technologies is also being fed into the Comprehensive Environmental Restoration, Compensation, and Liability Act (CERCLA) cleanup process being conducted at the S-3 Ponds site. An Engineering Evaluation/Cost Analy sis (EE/CA) prepared for the site contains proposed actions that incorporate the two existing passive treatment systems installed by EM-50 and EM-40 at the site. Final design for the CERCLA actions at the S-3 Ponds will take into consideration the results of studies conducted under this project. 


\section{SITE SETTING}

\subsection{S-3 PONDS GEOCHEMICAL AND HYDROGEOLOGIC SETTING}

The S-3 Ponds (Fig. 3.1) consisted of four unlined ponds constructed in 1951 on the west end of the Y12 Plant. The ponds had a storage capacity of 40 million L (10 million gallons). Liquid wastes, composed primarily of nitric acid plating wastes, containing various metals and radionuclides (e.g. uranium and technetium), were disposed of in the ponds until 1983. The volatile organic chemicals (VOCs) tetrachloroethylene (PCE) and acetone were also disposed of in the ponds. Pond wastes that remained were neutralized and denitrified in 1984, and the site was capped. The site is currently a large paved asphalt parking lot.

The Nolichucky shale bedrock that dips approximately 45 degrees to the southeast and has a strike of $\mathrm{N} 55 \mathrm{E}$ (parallel to $\mathrm{BCV}$ ) underlies the site. Overlying the bedrock is unconsolidated material that consists of weathered bedrock (referred to as residuum or saprolite), man-made fill, alluvium, and colluvium. Silty and clayey residuum comprises a majority of the unconsolidated material in this area. The thickness of residuum overlying the Nolichucky shale is typically between 5 and $10 \mathrm{~m}$ (15 and $30 \mathrm{ft})$ thick. Between the unconsolidated residuum and competent bedrock is a transition zone of weathered fractured bedrock. Remnant fracturing in the residuum and transition zone increases the permeability relative to the silt and clay matrix.

Waste disposal activities at the site have created a mixed waste plume of contamination in the underlying unconsolidated residuum and competent shale bedrock. The S-3 ponds are located on a hydrogeologic divide. The plume is over 400 feet deep directly beneath the ponds and extends 4,000 feet along geologic strike both east and west of the ponds. Contamination from the S-3 groundwater plume discharges to three tributaries of Bear Creek, North Tributary 1 (NT-1), NT-2, and the upper stem of Bear Creek (Watson et al., 1999). Three groundwater migration pathways that allow groundwater to discharge to surface water have previously been identified (LMES 1997). Pathways 1 and 2 are in the shallow unconsolidated zone and Pathway 3 is in the deeper shale bedrock. Pathway 3 is not addressed by this project. Pathway 1 is located adjacent and directly south of the S-3 Ponds and Pathway 2 is probably associated with an old historic stream channel of Bear Creek (Fig. 3.2).

Total dissolved solids (TDS) content of the groundwater plume is $>20,000 \mathrm{mg} / \mathrm{L}$ near the ponds. The S3 Ponds plume also contains elevated levels of nitrate, bicarbonate, and other ions, metals, uranium, technetium-99, and PCE. The plume is stratified, with the distribution of contaminants dependent on geochemical characteristics of the contaminants and groundwater. For example nitrate and technetium, which are not highly particle reactive, have the most extensive distribution in groundwater. Uranium and metals that are more reactive are not as deep and have not migrated as extensively away from the ponds.

The concentrations of analytes detected at the three Pathways (prior to barrier construction) are given in our previous Milestone report (Watson et al., 1999). Concentration can be very different at the three Pathways (Fig 3.2). Pathway 1 which is closer to the S-3 Ponds tends to have lower $\mathrm{pH}(<6.0)$, higher uranium, nitrate, bicarbonate, technetium, and total dissolved solids (TDS) content than Pathway 2. In FY 00 work at Pathway 1 was limited to evaluating selected ion-exchange resins in the laboratory for their effectiveness in removing uranium from the Pathway 1 groundwater. 
The Pathway 2 site is predominantly a shallow pathway for the migration of uranium contaminated groundwater (1-2 mg/L) to the upper reach of Bear Creek (Fig. 3.2). Nitrate concentrations are generally lower (i.e. $<100 \mathrm{mg} / \mathrm{L}$ ) at Pathway 2 but have been detected above $1,000 \mathrm{mg} / \mathrm{L}$ in some of the deeper piezometers. Technetium-99 is generally detected below $600 \mathrm{pCi} / \mathrm{L}$, and TDS concentrations (approximately $1,000 \mathrm{mg} / \mathrm{L}$ ) are generally lower than the shallow plume at Pathway 1 and deeper parts of the S-3 Ponds plume. Uranium contaminated groundwater is discharging to the creek near pathway 2 through seeps adjacent to the headwaters of Bear Creek.

Shallow groundwater flow directions west of the S-3 Ponds are generally to the southeast with a horizontal gradient of approximately 0.016 foot/foot (LMES 1997). Upward vertical gradients measured at Pathway 2 as shown on Fig. 3.3 are as high as 0.25 foot/foot between the competent bedrock and transition zone and 0.12 foot/foot between the transition zone and shallow unconsolidated zone (Watson and $\mathrm{Gu}, 1998$ ). Upward vertical gradients at the Pathway 1 site are approximately 0.05 foot/foot between deep well GW615 (247 feet deep) and GW247 (75 feet deep). The higher vertical gradients measured at Pathway 2 are probably related to groundwater discharge at the seeps located in Bear Creek. BCV receives an average of $137 \mathrm{~cm}$ (54 inches) of precipitation per year, much of it occurring in the winter months.

\subsection{SYSTEM DESIGN}

The treatment systems installed at Pathway 1 and Pathway 2 are conceptually quite different in how they were designed to hydraulically capture and treat contaminated groundwater. The system at pathway 1 is a more classical funnel (i.e. barrier) and gate installed perpendicular to the direction of groundwater flow. The system at Pathway 2 is a permeable trench (no barrier), oriented sub-parallel to the direction of groundwater flow, and designed to use the existing horizontal hydraulic gradients to route groundwater through the more permeable trench. The treatment media at pathway 1 are designed to be removable but the treatment media at Pathway 2 was placed in situ and buried in the trench. More detailed descriptions of the 2 treatment systems were provided in Watson et al. (1999), although field performance evaluation in FY 00 was primarily limited to the Pathway 2 permeable reactive barrier site, as stated previously.

A 225-ft long by approximately 30-ft deep trench was excavated near the S-3 Disposal Ponds at Pathway 2 , the primary uranium migration pathway to Bear Creek. The trench was filled with gravel except for a $26-\mathrm{ft}$ long section in the middle, which was filled with zero-valent iron. Guar gum slurry was added during excavation to prevent the trench walls from collapsing. The trench is oriented nearly parallel to the direction of groundwater flow and is designed to use both the natural groundwater gradient and permeability contrast between the gravel and iron in the trench and the native silt and clay outside the trench to direct flow through the iron treatment zone. Conceptually contaminated groundwater is captured on the upgradient end of the trench, treated as it is funneled through the iron in the middle of the trench, and then discharged on the downgradient end. Approximately 48 piezometers including 6 multi-port wells in the iron have been installed at the site. Additional details on the construction of the piezometers at Pathway 2 are provided in Watson and Gu (1998). 
DOE (EM-40) has modified the trench at Pathway 2 as part of the CERCLA actions being taken on the S3 Ponds groundwater plume. The trench has been extended an additional 100 feet downgradient to the west to capture more of the contaminated groundwater at Pathway 2 than is presently captured and enhance the migration of groundwater down the trench and through the iron filings. Groundwater from the trench extension is siphoned/pumped approximately 800 feet further west to a second zone of zero valent iron. The treatment medium is deployed in subsurface concrete boxes. The treated water flows into an infiltration trench downgradient of the second treatment zone.

In addition, in FY 00 a pipe was installed connecting the Pathway 1 barrier to the Pathway 2 sump. Water collected in the Pathway 1 barrier is pumped to the sump for treatment in the new treatment boxes further down the valley.

Performance evaluation activities have been focused on assessing the treatment effectiveness of the Iron barrier installed at Pathway 2. To be considered economically feasible compared to the base line technology of pump and treat, permeable reactive barriers must be capable of operating for well over 5 years prior to being removed or replaced. To reduce long-term stewardship costs this period must be extended even longer. The work being conducted at the Y-12 site has been focused on assessing the following types of long-term stewardship issues:

1. Passivation of the iron due to corrosion and mineral precipitation impacting the efficiency and longevity of contaminant removal.

2. System clogging and subsequent groundwater bypass due to precipitation of minerals and biofouling (especially if a biopolymer is used to install the system).

3. Determination of the oxidation state of the $\mathrm{U}$ (i.e., is it sorbed or precipitated). Changes in the oxidation state of $U$ can occur as a result of changes in groundwater geochemistry and iron corrosion over the long-term, with subsequent remobilization of $U$ (either as soluble $U$ or sorbed onto colloidal iron oxyhydroxide particles).

4. How easily $U$ will be remobilized after the barrier is no longer maintaining reducing conditions .

5. Long-term disposition of treatment media (will it have to be dug up after the iron stops working?).

6. Release of Byproducts (e.g., ferrous ion discharge, organic byproducts).

7. Installation Methods (e.g. pros and cons with using biopolymers to install shallow and deep barriers).

8. Hydraulic capture of groundwater (which has been identified as the primary reason for barrier failure at many sites). 


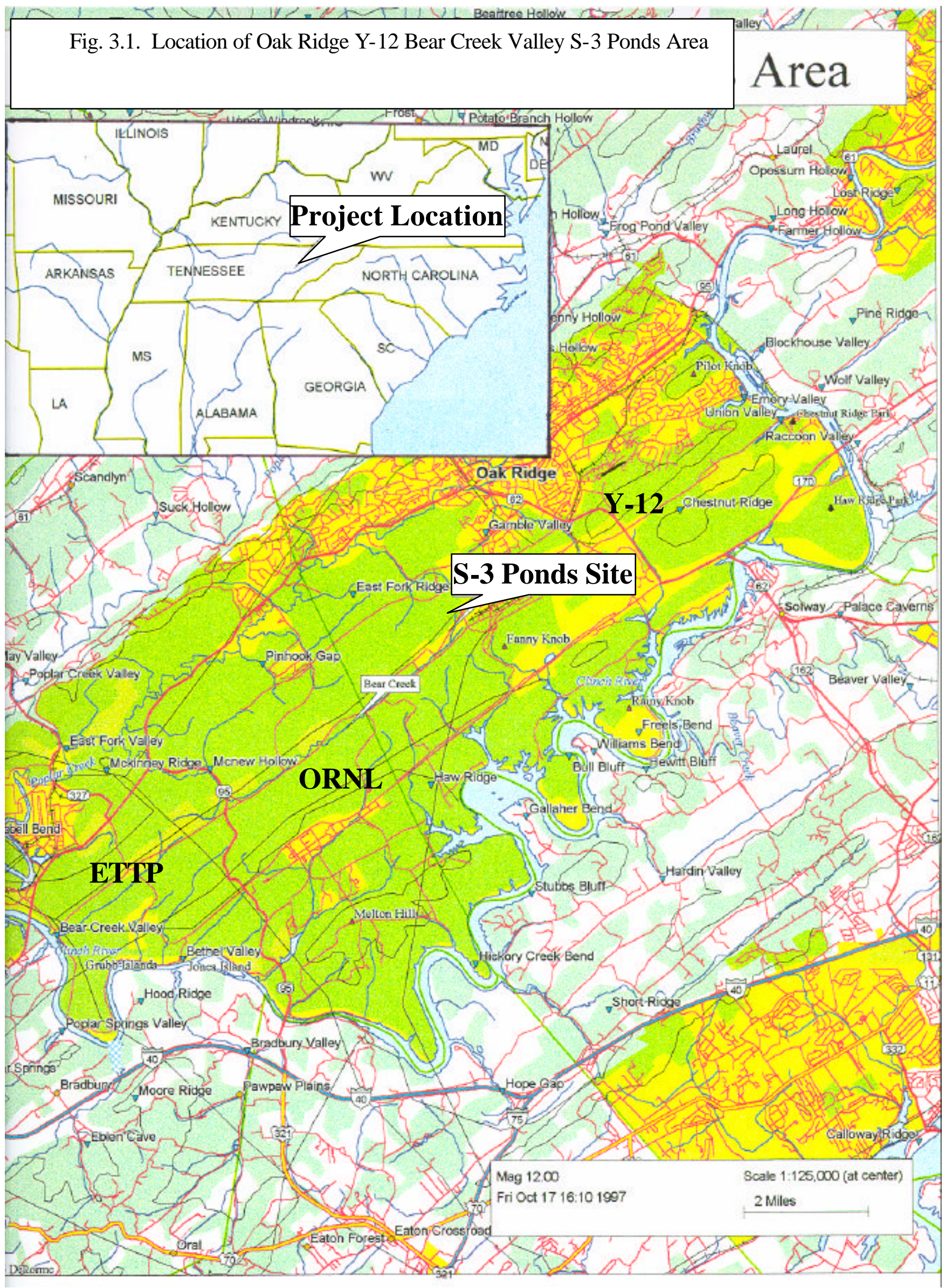




\section{S-3 Ponds Contaminant Migration Pathways}

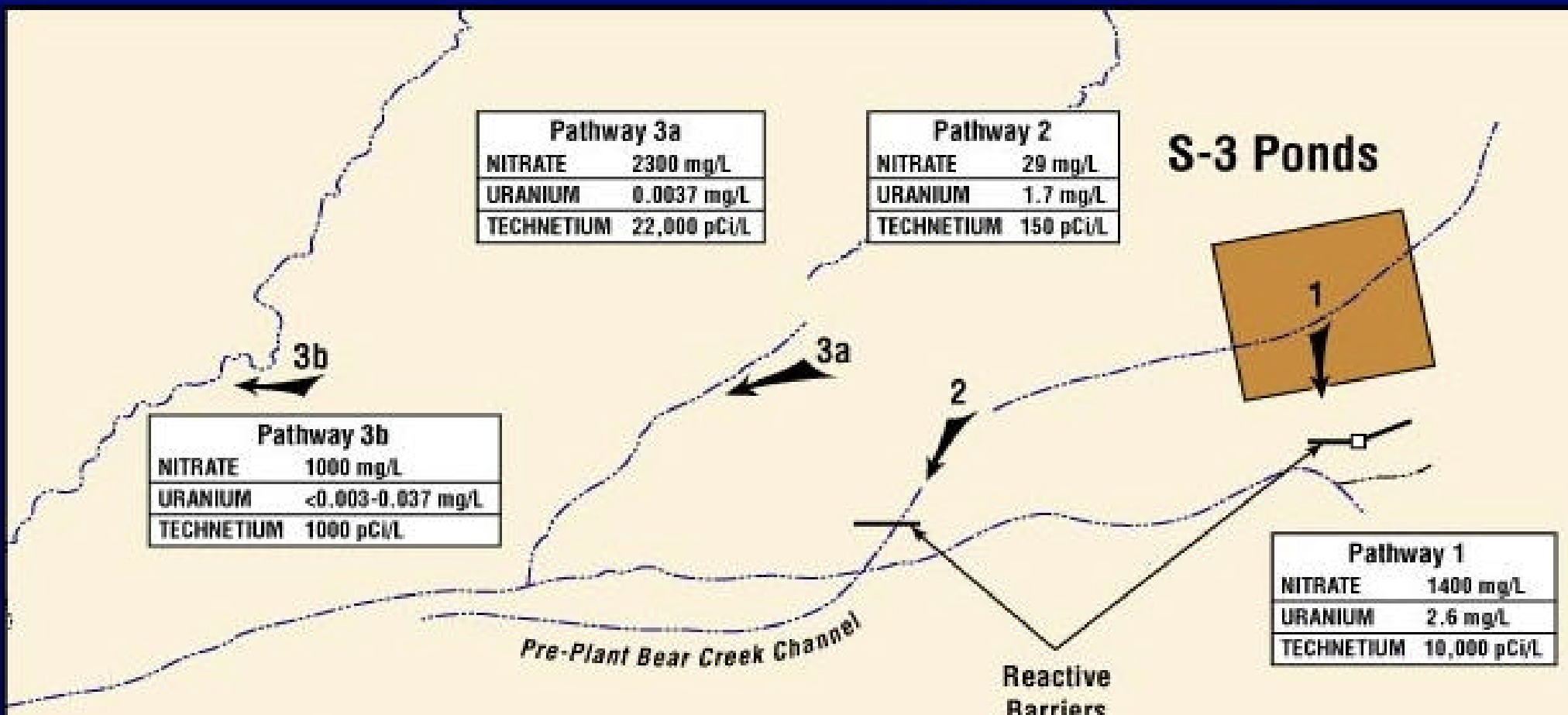

Contaminant

Migration

Pathways

Fig. 3.2. S-3 Ponds contaminant migration pathways 


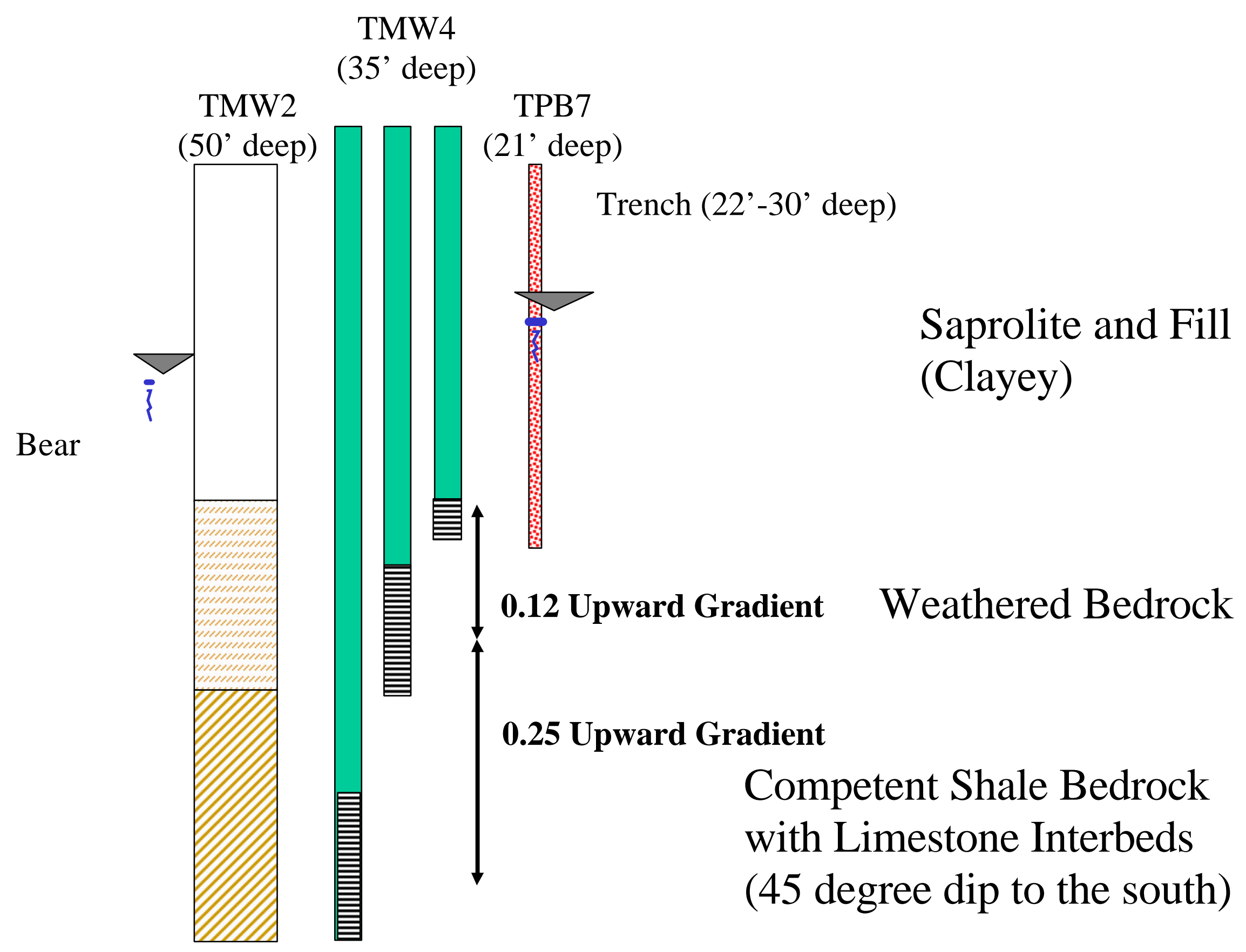

Fig. 3.3. Stratigraphy and vertical gradients at Pathway 2 


\section{URANIUM REMOVAL BY SYNTHETIC RESINS}

A variety of resins were tested using site groundwater to determine which were most effective in removing uranium from contaminated groundwater at the Y-12 S-3 Ponds area. The resins have several advantages over zero valent iron in the treatment of contaminated groundwater in that resins are often more selective and efficient in removing uranium while not generating unwanted byproducts such as ferrous iron (as by using zero-valent iron reactive media). High iron discharge was found to be a problem in the past when ZVI was used as the reactive media as a result of a low $\mathrm{pH}$ and high nitrate concentration of the Pathway 1 groundwater (Watson et al., 1999). Potential issue relevant to deployment could include cost, lifespan, and ability to deploy in a passive design. This study is part of a project to test the long-term effectiveness of permeable reactive media for treatment of contaminants associated with the S-3 Ponds site groundwater. In FY 96, preliminary tests were performed with several selected barrier materials such as zero-valent iron filings, peat moss, metal oxides, zeolite, and synthetic anion exchange resins. Data gathered from these studies have been considered in the CERCLA cleanup process being conducted at the S-3 Ponds site.

Previous studies have focused on using anion exchange resins such as Dowex $21 \mathrm{~K}$ and Dowex 1-X8 to remove uranium (as $\mathrm{UO}_{2}\left(\mathrm{CO}_{3}\right)^{2-}$ ) from the contaminated groundwater at the $\mathrm{S}-3$ Ponds site. Results indicated that the Dowex resins worked very well with the lower ionic strength groundwater from Pathway 2 but failed to remove significant quantities of uranium from the high ionic strength groundwater from pathways 1 and 3 (LMES, 1997). Two general categories of resins were tested in this new study; anion exchange resins and cation chelating resins. Prior to conducting the testing it was hypothesized that the chelation resins would be more effective in removing the uranium found in the high ionic strength groundwater associated with Pathways 1 and 3 than the anion exchange resins.

Synthetic Resins: A number of synthetic resins were evaluated for their sorption capacity and selectivity to remove uranium from contaminated groundwater; their general properties are listed in Table 4.1.

Groundwater: The site water that was tested was obtained from well PTMW2 which is located in Pathway 3 near Bear Creek North Tributary 1 (NT-1). The groundwater from this well had $\sim 5 \mathrm{mg} / \mathrm{L} \mathrm{U}$, $11,640 \mathrm{mg} / \mathrm{L} \mathrm{NO}_{3}{ }^{-}, 667 \mathrm{mg} / \mathrm{L} \mathrm{HCO}_{3}{ }^{-}, 685 \mathrm{mg} / \mathrm{L} \mathrm{Cl}^{-}$and a $\mathrm{pH}$ of 5. Simulated groundwater spiked with 20 $\mathrm{mg} / \mathrm{L} \mathrm{U}$ was also used in this study to determine if the resins removed uranium similarly under other geochemical conditions. The simulated groundwater had $600 \mathrm{mg} / \mathrm{L} \mathrm{HCO}_{3}{ }^{-}, 500 \mathrm{mg} / \mathrm{L} \mathrm{NO}_{3}{ }^{-}, 20 \mathrm{mg} / \mathrm{L} \mathrm{U}$ and a $\mathrm{pH}$ of 8 . The synthetic simulated groundwater is probably most representative of groundwater conditions at Pathway 2. 
Table 4-1. General properties of selected resins used in the batch tests.

\begin{tabular}{|l|l|l|c|c|}
\hline \multicolumn{1}{|c|}{ Resin } & \multicolumn{1}{|c|}{ Type } & \multicolumn{1}{c|}{ Functional group } & Mesh Size & $\begin{array}{c}\text { Estimated } \\
\text { Cost }\end{array}$ \\
\hline Eichrom Diphonix & Cation chelating resin & Diphosphonic acid & $30-80$ & unknown \\
\hline Bio-Rad Chelex 100 & $\begin{array}{l}\text { Weakly acidic cation } \\
\text { chelating resin }\end{array}$ & $\begin{array}{l}\text { Paired iminodiacetate } \\
\text { ions }\end{array}$ & $50-100$ & $\$ 265 / \mathrm{cu} \mathrm{ft}$ \\
\hline Purolite A-830 & Anion exchange resin & Quaternary ammonium & unknown & $\$ 120 / \mathrm{cu} \mathrm{ft}$ \\
\hline Purolite A-520E & Anion exchange resin & Triethylamine & $40-60$ & $\$ 200 / \mathrm{cu} \mathrm{ft}$ \\
\hline Purolite D3696 & $\begin{array}{l}\text { Bifunctional anion } \\
\text { exchange resin }\end{array}$ & Trihexyl/triethyl amine & $40-60$ & unknown \\
\hline Dowex 1-X8 & $\begin{array}{l}\text { Strong anion exchange } \\
\text { resin }\end{array}$ & Trimethylamine & $20-50$ & $\$ 180 / \mathrm{cu} \mathrm{ft}$ \\
\hline Dowex 21K & Anion exchange resin & Trimethylamine & unknown & $\$ 180 / \mathrm{cu} \mathrm{ft}$ \\
\hline
\end{tabular}

Methods: The removal of uranium by the different resins under field and simulated groundwater conditions was investigated in batch experiments by shaking $0.1 \mathrm{~g}$ of resin (dry weight) in $15 \mathrm{ml}$ of groundwater in plastic scintillation vials ( $\sim 25 \mathrm{ml}$ in capacity) on an end-over-end shaker. A separate batch experiment was carried-out on field groundwater spiked with $20 \mathrm{mg} / \mathrm{L} \mathrm{U}$ to determine if the resins performed similarly under elevated $U$ concentrations. In these batch experiments, $1 \mathrm{ml}$ of sample solution was taken periodically at 1, 8, 24, and 168 hours (1 week) of shaking. Each of the $1 \mathrm{ml}$ extractions was added to $20 \mathrm{ml}$ of Distilled deionized water in separate scintillation vials and stored in refrigeration. More detailed batch studies were conducted on the four best-performing resins in the previous batch studies by shaking $0.1 \mathrm{~g}$ (dry weight) of resin in $100 \mathrm{ml}$ of field groundwater $(\sim 5 \mathrm{mg} / \mathrm{L} \mathrm{U})$ in plastic bottles ( $200 \mathrm{ml}$ capacity). In this batch experiment, initial removal of $U$ from groundwater was also investigated by extracting $1 \mathrm{ml}$ of groundwater from the bottles at $30 \mathrm{sec}, 1 \mathrm{~min}, 2 \mathrm{~min}, 5 \mathrm{~min}, 10 \mathrm{~min}, 30 \mathrm{~min}, 1 \mathrm{hr}, 4 \mathrm{hr}, 8 \mathrm{hr}, 24 \mathrm{hr}$, and 1 wk after shaking. Each of the $1 \mathrm{ml}$ samples was added to $20 \mathrm{ml}$ of Distilled deionized water in separate scintillation vials and stored in refrigeration.

Sample Analysis: Eichrom resin columns were used to extract U from ten mls of the diluted groundwater samples. The $\mathrm{U}$ in these samples was analyzed with a kinetic phosphorescence analyzer (ChemChek, KPA-11).

Results: Distribution coefficients $\left(\mathrm{K}_{\mathrm{d}}\right)$ were calculated for the resins based on the batch study results. The distribution coefficient is defined as the ratio of the amount of $\mathrm{U}$ sorbed (as $\mathrm{mg} \mathrm{g}^{-1}$ dry resin) divided by the concentration of $U$ remaining in the equilibrium solution (as $\mathrm{mg} \mathrm{mL}^{-1}$ ). Based on these distribution coefficient $\left(\mathrm{K}_{\mathrm{d}}\right)$ values, the synthetic resins (Diphonix and Chelex 100) removed the most $\mathrm{U}$ (at $\sim 5 \mathrm{mg} / \mathrm{L}$ and $20 \mathrm{mg} / \mathrm{L}$ ) from the high ionic strength groundwater (PTMW2) as compared to anion exchange resins (Table 4.2). Uranium was removed from the contaminated groundwater at over $80 \%$ with 1-h equilibration and over $90 \%$ with 8-h equilibration by both of these resins. These two resins therefore appear promising in remediating groundwater at the Pathway 1 and Pathway 3 sites. The most rapid removal of $U$ appeared to 
occur with Chelex 100. In the initial batch tests on the $15 \mathrm{mls}$ of groundwater, Chelex 100 removed more U after 1 to 24 hours of shaking as compared to Diphonix in the PTMW2 (Pathway 3) groundwater spiked with $20 \mathrm{mg} / \mathrm{L} \mathrm{U}$. Uranium concentrations ranged from $0.95 \mathrm{mg} / \mathrm{L}$ at $1-\mathrm{hr}$ equilibrium to $0.08 \mathrm{mg} / \mathrm{L}$ at $24-\mathrm{h}$ equilibrium for Diphonix and $0.17 \mathrm{mg} / \mathrm{L}$ at 1-hr equilibrium to $0.03 \mathrm{mg} / \mathrm{L}$ at 24-hr equilibrium for Chelex 100 . However, in the batch study conducted on the $100 \mathrm{mls}$ of groundwater from the site, Chelex 100 exhibited greatest removal of $U$ for the first 10 minutes of shaking (Table 4.3 and Fig. 4.1). After 10 minutes, Diphonix equaled or out performed Chelex 100. A similar trend was observed in the unspiked groundwater that contained $\sim 5 \mathrm{mg} / \mathrm{L} \mathrm{U}$. The results from the $100 \mathrm{ml}$ batch test is probably more reliable than the $15 \mathrm{ml}$ batch test because a relatively large volume of sample solution was used for the experiment to lower the experimental error.

Table 4-2. Distribution coefficients $(\mathrm{Kd})(\mathrm{mL} \mathrm{g}-1)$ of $\mathrm{U}$ on resins - groundwater from PTMW2 (15 mL test).

\begin{tabular}{|c|c|c|c|c|}
\hline Resin & $1 \mathrm{hr}$ & $8 \mathrm{hr}$ & $24 \mathrm{hr}$ & $168 \mathrm{hr}$ \\
\hline \multicolumn{5}{|c|}{ Field Conditions $(U=\sim 5 \mathrm{mg} / \mathrm{L})$} \\
\hline Eichrom Diphonix & 7,584 & 38,954 & 27,922 & 104,843 \\
\hline Chelex 100 & 13,916 & 24,457 & $154.9^{*}$ & 50,869 \\
\hline Purolite A-830 & 426.1 & 576.2 & 703.6 & 14,726 \\
\hline Purolite D-3696 & 25.7 & 24.8 & 24.5 & 19 \\
\hline Dowex 1-X8 & 7.1 & 21.3 & 24.6 & 52.4 \\
\hline Purolite A-520E & 9.7 & 2 & 0.3 & 7.2 \\
\hline \multicolumn{5}{|c|}{ Additional $20 \mathrm{mg} / \mathrm{L} U$ added to the groundwater $(\sim 25 \mathrm{mg} / \mathrm{L} \mathrm{U})$} \\
\hline Eichrom Diphonix & 6,159 & 26,722 & 46,717 & 47,682 \\
\hline Chelex 100 & 21,762 & 30,759 & 71,844 & 40,502 \\
\hline Purolite A-830 & 473.3 & 673 & 567 & $\mathrm{NA}^{* *}$ \\
\hline Purolite D-3696 & 0.43 & 0.63 & 19.2 & NA \\
\hline Dowex 1-X8 & 1.7 & 2.6 & 5 & NA \\
\hline Purolite A-520E & 4.1 & 4.6 & 3.2 & NA \\
\hline Dowex $21 \mathrm{~K}$ & 2.1 & 3.6 & 3.1 & NA \\
\hline
\end{tabular}

${ }^{*}$ Suspected error. ${ }^{* *} \mathrm{NA}=$ not analyzed 
Table 4-3. Distribution coefficients (Kd) (mL g-1) of U on resins - groundwater from PTMW2 (100 mL test).

\begin{tabular}{|l|l|l|l|l|l|l|l|l|l|l|l|}
\hline Resin & $30 \mathrm{sec}$ & $1 \mathrm{~min}$ & $2 \mathrm{~min}$ & $5 \mathrm{~min}$ & $10 \mathrm{~min}$ & $30 \mathrm{~min}$ & $1 \mathrm{hr}$ & $4 \mathrm{hr}$ & $8 \mathrm{hr}$ & $24 \mathrm{hr}$ & $168 \mathrm{hr}$ \\
\hline $\begin{array}{l}\text { Eichrom } \\
\text { Diphonix }\end{array}$ & 6.26 & 26.0 & 310.0 & 521.9 & 1,146 & 2,935 & 6,736 & 21,480 & 25,518 & 39,406 & 92,894 \\
\hline Chelex 100 & 518.8 & 743.8 & 765.8 & 1,107 & 1,286 & 1,484 & 3,320 & 4,429 & 6,307 & 11,252 & 48,214 \\
\hline $\begin{array}{l}\text { Purolite } \\
\text { A-830 }\end{array}$ & 462.2 & 515.7 & 571.2 & 586.5 & 687.9 & 752.2 & 776.6 & 986.8 & 1,085 & 1,104 & 1,174 \\
\hline Dowex 1-X8 & 94.4 & 123.3 & 179.5 & 185.6 & 206.3 & 245.3 & 473.2 & 496.1 & 605.0 & 914.9 & 1,557 \\
\hline
\end{tabular}

Purolite A-830 removed more U from the S-3 site groundwater as compared to the other anion exchange resins (Table 4.2 and fig. 4.2). This resin performed similar to Chelex 100 in the first 2-min of the batch test (Table 4.3 and fig.4.1). However, after the first 2 minutes, Chelex 100 out performed the Purolite A-830. Similar to previous results (LMES, 1997), Dowex $21 \mathrm{~K}$ did not perform well in these batch tests due to the high ionic strength nature of the groundwater.

The anion-exchange resins removed more $\mathrm{U}$ from the simulated low ionic strength groundwater as compared to the S-3 site groundwater (Table 4.4) because of the added bicarbonates and a relatively high $\mathrm{pH}$ conditions. Under such conditions, uranyl is complexed with carbonates and forms anionic species and is therefore effectively removed by these anion exchange resins. Dowex 1-X8 and Purolite A-520E showed the greatest removal of $U$ as compared to the other resins in the simulated groundwater batch study. These anion exchange resins could be considered for use at Pathway 2. Similar Kd values were observed for the chelating resins in both the simulated and S-3 site groundwater batch studies (Tables 4.3 and 4.4). 
Table 4-4. Distribution coefficients (Kd) (mL g-1) of $U$ on resins from simulated groundwater.

\begin{tabular}{|l|c|c|c|c|}
\hline \multicolumn{1}{|c|}{ Resin } & $1 \mathrm{hr}$ & $8 \mathrm{hr}$ & $24 \mathrm{hr}$ & $168 \mathrm{hr}$ \\
\hline Eichrom Diphonix & 12,519 & 17,418 & 27,554 & 22,230 \\
\hline Chelex 100 & 9,195 & 66,855 & 125,184 & 45,350 \\
\hline Purolite A-830 & 18,528 & 1,436 & 202 & 166.2 \\
\hline Purolite D-3696 & 87,854 & 424,987 & 559,714 & NA \\
\hline Dowex 1-X8 & 399,332 & 552,621 & $2,514,603$ & NA \\
\hline Purolite A-520E & 501,938 & $1,027,743$ & $1,095,060$ & NA \\
\hline Dowex 21K & 15,048 & 16,834 & 15,168 & NA \\
\hline
\end{tabular}

$\mathrm{NA}=$ not analyzed.

Conclusions and Recommendations: The Diphonix and Chelex 100 resins show the most promising results for removing $\mathrm{U}$ from the Pathways 1 and 3 groundwater types with a high ionic strength (nitrate and bicarbonate) and a low $\mathrm{pH}$. Uranium was removed from the contaminated groundwater at over $80 \%$ with 1-h equilibration and over $90 \%$ with 8 -h equilibration by both of these resins. These two resins therefore appear promising in remediating groundwater at the Pathway 1 and Pathway 3 sites. Dowex 1-X8 and Purolite A$520 \mathrm{E}$ showed the greatest removal of $\mathrm{U}$ as compared to the other resins in the simulated groundwater with a high bicarbonate concentration. These anion exchange resins could be considered for use at Pathway 2 for uranium removal. It is recommended that field column study tests be conducted to further assess the suitability of these resins for use in the field. 


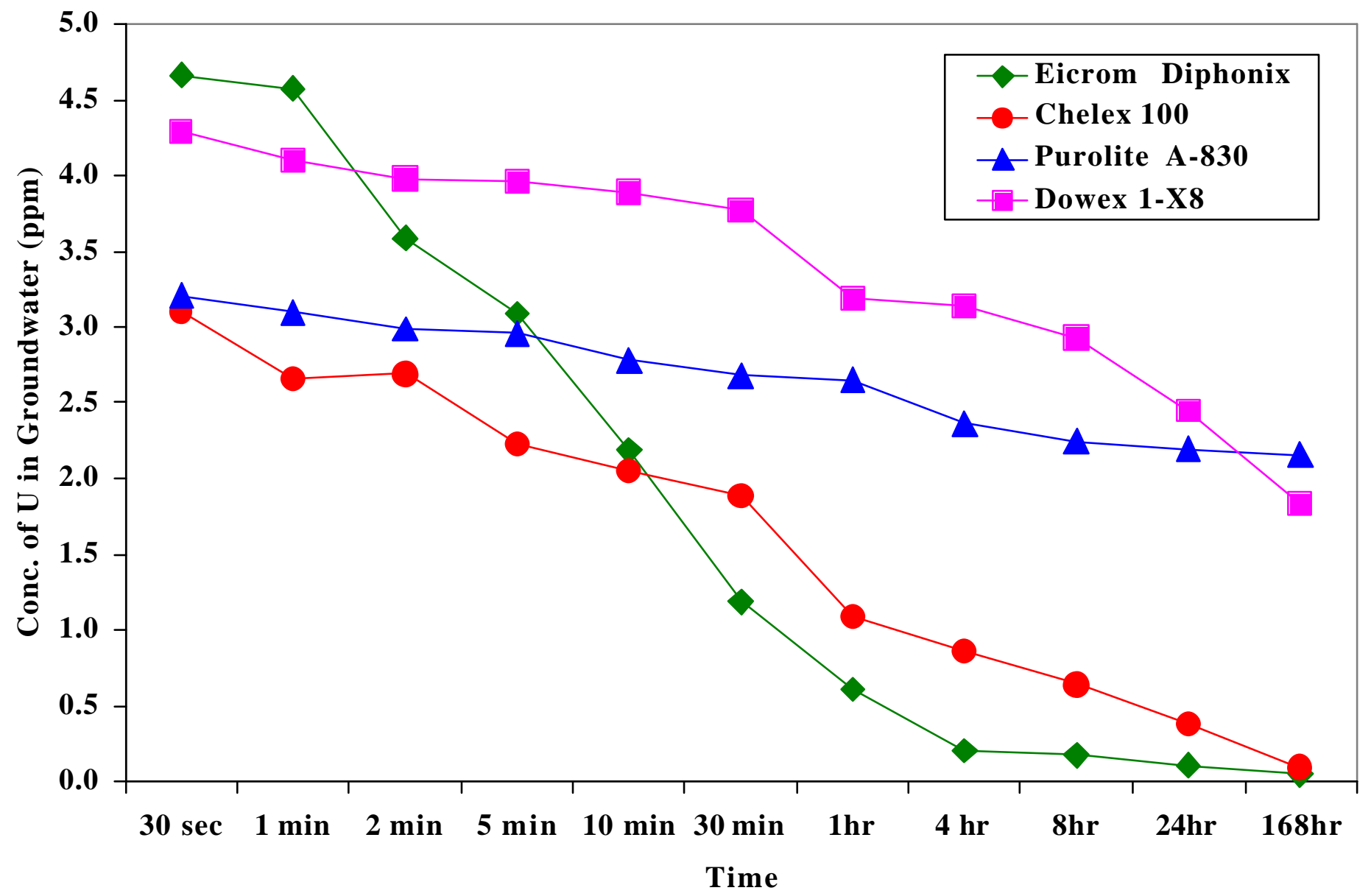

Fig. 4.1. Removal of uranium from high ionic strength groundwater by synthetic resins $(100 \mathrm{~mL}$ test $)$. 


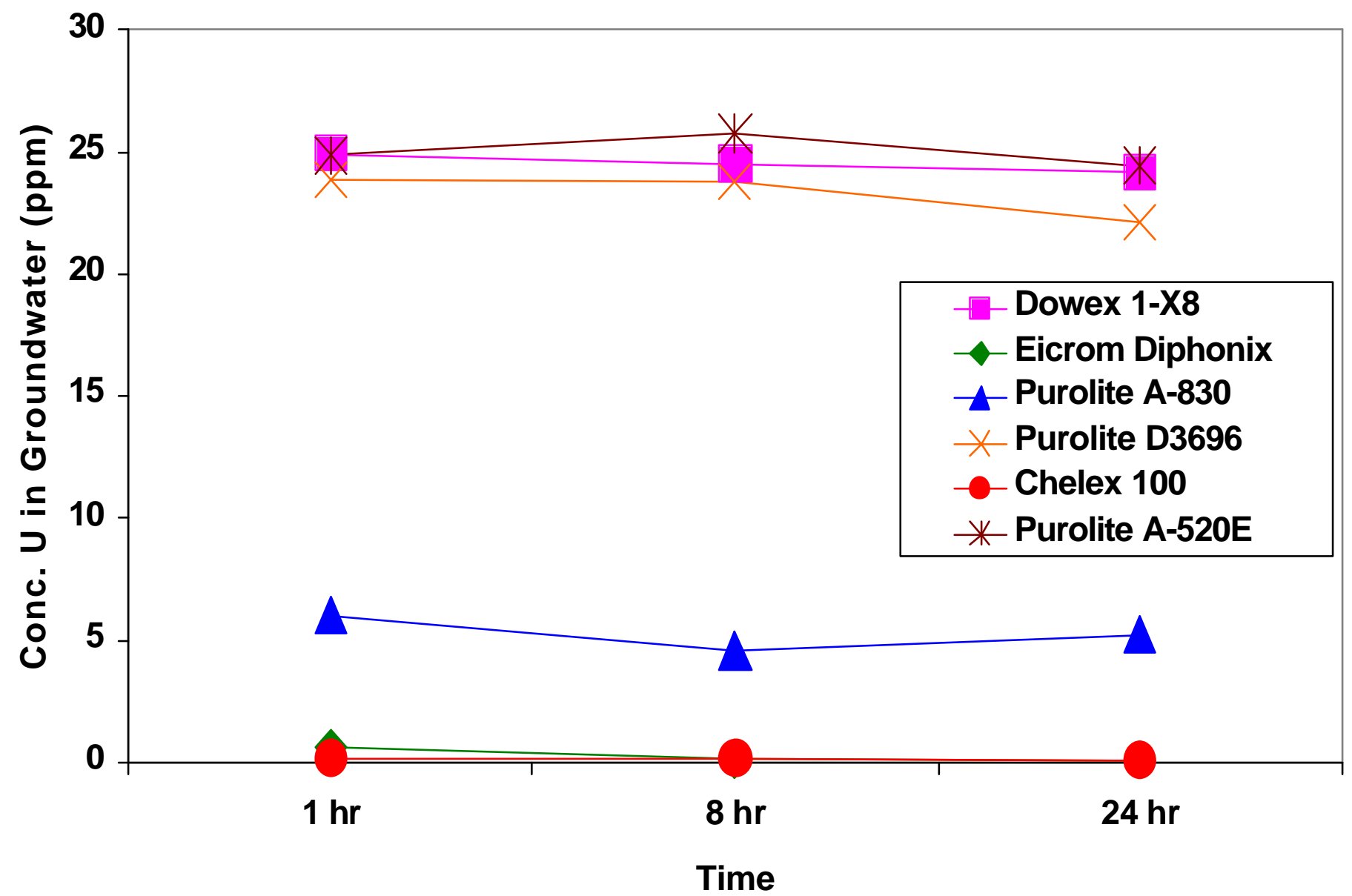

Fig. 4.2. Removal of uranium from high ionic strength groundwater from Y-12 (original conc. U $\sim 4.7$ ppm) spiked with $\sim 20$ ppm $U$ by synthetic resin. 


\section{RESULTS OF GROUNDWATER MONITORING AT PATHWAY 2}

During the last 3 years, data has been collected to assess the performance of the iron reactive barrier at Pathway 2 with respect to contaminant removal (such as uranium, nitrate, and technetium), byproduct formation (such as total and ferrous iron concentrations), concentration profiles of other major cations and anions, and hydraulic capture. Analytical data from field monitoring and laboratory analyses are summarized in Appendix A. Groundwater level data is provided in Appendix B. The locations of monitoring points in relationship to the Pathway 2 barrier are shown on Figure 5.1.

\subsection{URANIUM REMOVAL}

Uranium concentration within and near the iron reactive barrier is plotted in Fig. 5.2 for some selected monitoring wells. As previously reported (Watson et. al., 2000) results indicated that uranium was removed within the iron portion of the barrier and the uranium concentration in monitoring wells such as TMW9 (middle of the $\mathrm{Fe}^{0}$ section) and DP19S and DP19M (in the downgradient part of the $\mathrm{Fe}^{0}$ section) were generally very low $(<0.05 \mathrm{mg} / \mathrm{L})$ or below detection limits compared to uranium concentration in the upgradient wells (e.g., TMW12, TMW11, DP13). From February 1998 to September 1998, uranium also appeared to be partially removed in TMW11 (located in the pea gravel adjacent and upgradient of the $\mathrm{Fe}^{0}$ section of the trench) perhaps because it is adjacent to the iron barrier $(\sim 2 \mathrm{ft})$ and thus influenced by the strong reducing environment created by the iron barrier. However, $\mathrm{U}$ increased steadily to $\sim 0.6 \mathrm{mg} / \mathrm{L}$ in the July 1999 sample (although it decreased to $<0.2 \mathrm{mg} / \mathrm{L}$ in the April 2000 sample) suggesting that the iron reactivity may be decreasing at the upgradient end of the barrier. Uranium concentration in other monitoring wells within the $\mathrm{Fe}^{0}$ portion of the barrier (DP18S,M,D; DP19S,M,D; DP20S,M,D; DP21S; DP23 S,M,D) are also low or below the detection limit. (Apendix A). These field observations are consistent with our previous laboratory studies, which showed that uranium can be effectively and rapidly reduced by $\mathrm{Fe}^{0}$ filings (Gu et al., 1998).

Uranium concentration in some middle and deep wells within the iron barrier (e.g., DP22M, DP21M, and DP20D and DP21D) appeared to be higher than expected (ranged from $\sim 0.2-1.0 \mathrm{mg} / \mathrm{L}$ ). These wells are in the upgradient portion of the iron near the bedrock interface where upward hydraulic gradients and flow may dominate. Therefore, the elevated $U$ concentrations in these wells are probably related to the higher inflow of untreated groundwater at these locations. Similar trends are observed for nitrate in these deep wells (e.g., DP20D, DP21D and DP22D). Uranium concentrations in upgradient well TMW11 and wells DP22M, DP22S, and DP21M located the furthest upgradient but still in the iron, have an increasing U concentration trend starting in the spring of 1999 that may be related to a decrease in reactivity in the upgradient portion of the iron (Sections 6 and 7).

Although non-detectable amounts of uranium were found in the downgradient well TMW7, suggesting that the iron barrier is removing or retaining uranium from the contaminated groundwater, uranium was high in downgradient wells in which treated groundwater was supposed to be flowing. These wells include TMW6, DP11, DP8, DP15D. Of particular interest is DP11 since it is located in the downgradient soil very near the $\mathrm{Fe}^{0}$ filings. In DP11, the $\mathrm{U}$ content rose to as high as $2.7 \mathrm{mg} / \mathrm{L}$ in the October 99 sample, however, it decreased to $1.16 \mathrm{mg} / \mathrm{L}$ in the last sample taken in April 2000. These data suggest that treated groundwater is rapidly becoming recontaminated due to mobilization of uranium on downgradient soils and/or these wells are intercepting flowpaths not treated by the reactive barrier. 
Seasonal fluctuations also appear to impact the concentration of uranium in groundwater. Preliminary analysis suggests that $U$ content was the highest in the samples collected during the summer months compared to those collected during the winter months (Appendix A). This trend may be related to dilution that occurs in the winter due to the higher rainfall and greater recharge.

\subsection{NITRATE}

Nitrate concentration within and near the iron reactive barrier is plotted in Fig. 5.3 for some selected monitoring wells. Nitrate concentration in monitoring wells (e.g., TMW7; TMW9; TMW11; DP18S,M,D; DP19S,M,D; DP20S,M; DP21S,M; DP22S; DP23 S,M,D) was low or non-detectable in groundwater collected from December 1997 to April 1999 (Appendix A). Although there was an increase in nitrate concentration in many of these monitoring wells (TMW9, DP18D, DP19S,M, DP20S,M, DP21S) during the April 2000 sampling round it is not certain if this is a sampling and analysis artifact or a longer term trend. Nitrate concentration was low in the downgradient flow path of the iron barrier (including monitoring wells DP7, DP9, DP11; DP14S, DP15S, DP16S,D; and DP17S,D) in the December 1997 to April 1999 samples. However, nitrate dramatically increased in the April 2000 samples from these wells. Nitrate concentration in upgradient DP13 remained relatively constant ( 70 - $120 \mathrm{mg} / \mathrm{L})$ from December 1997 to April 1999, however it decreased in April 2000, the last sampling event.

These results indicate that the iron barrier not only reduced uranium but also degraded nitrate in the groundwater, although nitrate reduction may also be partially attributed to microbial denitrification by denitrifiers as will be discussed later (Section 6.5).

High nitrate concentrations (often greater than $1000 \mathrm{mg} / \mathrm{L}$ ) were sometimes observed in deep piezometers such as DP14D, DP15D, DP20D, DP21D, and DP23D. Again, this observation could be due to the upward flow of deeper contaminated groundwater near the bedrock saprolite interface. An increasing trend in nitrate concentrations in TMW11 and DP22M since the spring of 1999 may be related to a decrease in reactivity in the upgradient portion of the iron (Sections 6 and 7).

\subsection{SULFATE AND SULFIDE}

Sulfate concentration within and near the Pathway 2 iron reactive barrier is plotted in Fig. 5.4 for some selected monitoring wells. A significant decrease in sulfate concentration in and downgradient of the iron barrier is evident. Concentrations of sulfate in piezometers located in the iron such as DP18S,M,D, DP19M, DP20S,M, DP23M, DP21S were generally quite low compared to concentrations detected in upgradient wells. Sulfate in DP20m has also drastically decreased since October 1999 (Appendix A). These observations are consistent with some previous studies that showed groundwater $\mathrm{SO}_{4}{ }^{2-}$ contents decreased through the $\mathrm{Fe}^{0}$ barriers at the Moffett Field and Lowry AFB sites; the Elizabeth City, NC U.S. Coast Guard site; and through laboratory-simulated column studies with a continuous input of sulfate and bicarbonate solutions (Gu et al., 1999).

A higher reduction of $\mathrm{SO}_{4}{ }^{2-}$ to $\mathrm{S}^{2-}$ is also observed within the barrier, as $\mathrm{S}^{2-}$ is present in larger amounts at the interface of the pea gravel (TMW11) within the iron barrier (TMW9) and down gradient side of the $\mathrm{Fe}^{0}$ section (TMW7) compared to other pea gravel portions of the trench (e.g., TMW12 and 6). However, it should be pointed out that much of the sulfide produced may be rapidly precipitated as FeS because of its low solubility. This explains a relatively low sulfide concentration observed in most of the wells. The precipitation of $\mathrm{FeS}$ was confirmed by the analysis of Fe-core samples as will be discussed below. These observations 
suggest that sulfate was reduced to sulfide by $\mathrm{Fe}^{0}$ or a combination of $\mathrm{Fe}^{0}$ and sulfate-reducing bacteria under anaerobic conditions. This observation is important with respect to mineral precipitate formation and possible cementation within the iron barrier due to the formation of ferrous sulfide, which can affect the long-term performance of the reactive barrier system (Section 6).

Over the past 3 years, sulfate appears to be decreasing steadily in upgradient monitoring wells; for example, sulfate has decreased from about $150 \mathrm{mg} / \mathrm{L}$ to about $60 \mathrm{mg} / \mathrm{L}$ in TMW12. It is unclear what is causing this downward trend.

\subsection{BICARBONATE/CARBONATE}

The bicarbonate/carbonate $\mathrm{HCO}_{3}{ }^{-} / \mathrm{CO}_{3}{ }^{-}$concentrations in the groundwater at the site were generally high (sometimes $>500 \mathrm{mg} / \mathrm{L}$ ) both up- and downgradient of the barrier (Fig. 5.5 and Appendix A). These high values are due to the acidification of the S-3 ponds and subsequent release of the carbonates from the bedrock and $\mathrm{CaCO}_{3}$ used in neutralization of the pond water before capping. Within the trench, the highest values appeared to be upgradient of the iron both in TMW12 and TMW11. The concentration drops dramatically within the $\mathrm{Fe}^{0}$ portion of the barrier (TMW9) and in TMW7 located on the downgradient edge of the $\mathrm{Fe}^{0}$ and pea gravel. Within the $\mathrm{Fe}^{0}$ portion of the trench, bicarbonate is highest in the upgradient section with concentrations in the deeper 26-foot deep DP22M port generally being slightly higher than that in the shallower 16-foot deep DP22S. The bicarbonate concentration was even higher in this section of the barrier compared with the upgradient background well TMW12. This high bicarbonate content at the upgradient portion of the barrier may have played a role in the cementation present in this portion of the barrier (Section 6 ). In the downgradient portion of the barrier, the shallow section (16 feet deep) generally has a higher bicarbonate concentration. This higher concentration in the shallow zone is probably related to a shorter residence time in this section of the iron. Similar trends were observed for calcium within the $\mathrm{Fe}^{0}$ portion of the barrier as will be discussed below in Section 5.6.

\subsection{FERROUS AND TOTAL IRON}

Ferrous iron discharge to Bear Creek has been one of the major concerns regarding the implementation and potential negative impacts related to using iron barriers in the subsurface at Y-12 (Fig. 5.6 and Appendix A). In particular, when the iron barrier was installed using the Guar Gum biopolymer in November 1997, a high ferrous iron concentration was observed in the groundwater, Bear Creek and seeps. On December 15, 1997 , the ferrous iron concentration was as high as $150 \mathrm{mg} / \mathrm{L}$, and total iron concentration was $>700 \mathrm{mg} / \mathrm{L}$ in the central monitoring well (TMW9) located within the iron barrier (Appendix A). Highest total iron values were observed in TMW9 (719.3-423.63 mg/L) located in the middle of the $\mathrm{Fe}^{0}$ filings portion of the trench, TMW7 (239.23-142.6 mg/L) located just downgradient of the iron in the pea gravel section of the trench, and TMW11 (141.3 mg/L) located just upgradient of the iron. However, ferrous iron concentration decreased rapidly over time (within 3 weeks after installing the iron barrier) and became stabilized after approximately 3 months of operation.

The high initial ferrous and total iron concentrations observed in the groundwater and creek may be attributed to the following factors: 1) a rapid initial oxidation of $\mathrm{Fe}^{0}$ filings, particularly some fine iron dusts, when they were first introduced into the trench; 2) the use of guar gum, which may react with the $\mathrm{Fe}^{0}$ filings and resulted in a highly reducing environment; and 3) disturbances in the soil, which leads to fine Fe-bearing and $\mathrm{Fe}$ particulate in the groundwater. 
Both ferrous and total iron concentration dropped to nearly non-detectable after March 1998 in both TMW9 and TMW6. Ferrous iron concentration and total iron in TMW7 (downgradient of the iron) also dropped to nearly zero after April 1998 and remained relatively constant thereafter. Ferrous iron concentration in TMW11 (upgradient of the iron) where groundwater flow enters the iron barrier was higher during the first year, probably because oxygen content of the groundwater was high prior to entering the barrier causing greater corrosion of the iron. For the past year the concentration of ferrous iron in TMW11 has been close to or below detection limits most likely because cementation within the upgradient portion of the iron has reduced the amount of iron corrosion (Section 6).

It is also noted that, within the $\mathrm{Fe}^{0}$ filing portion of the trench, lower Fe concentrations are usually present in the deep zone, while relatively higher concentrations occur in the shallow zone. The higher iron concentration in the shallow zone may be related to higher oxygen content and shorter residence times in the shallow groundwater. Up and downgradient groundwater Fe concentrations outside of the trench were usually $<10 \mathrm{mg} / \mathrm{L}$, with the majority $<5 \mathrm{mg} / \mathrm{L}$. The concentration of ferrous iron in DP11 (a downgradient well adjacent to the trench) has been slowly increasing over the past year from $1.6 \mathrm{mg} / \mathrm{L}$ to $14.5 \mathrm{mg} / \mathrm{L}$. Higher $\mathrm{U}$ concentrations were also detected in DP11 over this same time period. It is unclear what has caused this increase in iron and $\mathrm{U}$ concentration but it could be related to changing groundwater flow paths in the vicinity of this DP11well.

Ferrous iron concentrations in other piezometers are also low $(<10 \mathrm{mg} / \mathrm{L})$ and are generally less than 2 $\mathrm{mg} / \mathrm{L}$ in the Seeps and Bear Creek. These results suggest that ferrous iron discharge as result of the iron barrier does not appear to be as much of a concern as initially perceived. As long as the groundwater $\mathrm{pH}$ in the iron barrier is above neutral, we would expect a minimal impact of iron discharge to groundwater and the Creek.

\subsection{CALCIUM AND OTHER MAJOR CATIONS}

An analysis of several major cations $\left(\mathrm{Ca}^{2+}, \mathrm{Mg}^{2+}\right.$, and $\left.\mathrm{Mn}^{2+}\right)$ indicates that these metal cations are partially retained or precipitated within the iron barrier (Fig. 5.7 and Appendix A). The Ca-rich bedrock and the limestone used for the neutralization of the S-3 ponds, combined with a strong nitric acid leachate from the S3 ponds, contributed to high amounts of $\mathrm{Ca}^{2+}$ in the groundwater at the S-3 site. Highest $\mathrm{Ca}^{2+}$ values occurred where the groundwater enters the $\mathrm{Fe}^{0}$ portion of the trench at DP21d $(517 \mathrm{mg} / \mathrm{L})$ and at nearby TMW11 $(548$ $\mathrm{mg} / \mathrm{L})$ in the pea gravel, and downgradient in well DP15d (1027 mg/L). These sampling points, DP21 (189$517 \mathrm{mg} / \mathrm{L})$, TMW11 (105-548 mg/L) and DP15d (43-1027 mg/L), also had the widest range of $\mathrm{Ca}^{2+}$ values detected (Appendix A).

Calcium concentrations in the central well (TMW9) and TMW7 (next to the downgradient edge of the iron barrier) were about an order of magnitude lower than in upgradient wells TMW11, and DP13 suggesting $\mathrm{Ca}$ is being retained by the iron barrier. These results were expected on the basis of our laboratory studies because an increased $\mathrm{pH}$ within the iron barrier and a relatively high concentration of bicarbonate in the groundwater may have induced the chemical precipitation of Ca-carbonate or a mixture of $\mathrm{Fe}$ - and $\mathrm{Ca}$ oxyhydroxide coprecipitates. Additionally, TMW7 showed a steady decrease in Ca over the 2.5 year monitoring period. Similar concentrations of Ca were observed in the upgradient background well (TMW12) and in the upgradient peizometer in the $\mathrm{Fe}^{0}$ portion of the barrier (DP22M). In the shallow zone of the iron portion of the barrier Ca was higher in the upgradient DP22S compared to the downgradient DP19S. Calcium concentrations were also much lower in DP19M compared to DP22S,M. This is probably due to depletion of $\mathrm{Ca}$ due to precipitation of $\mathrm{CaCO}_{3}$ within the barrier. The results are also consistent with the observations by SAIC's field column studies which showed a significant precipitation of $\mathrm{CaCO}_{3}$ and eventual clogging of the 
iron column. Such precipitate formation within the iron barrier may adversely affect the long-term performance of the reactive barrier and will passivate the iron surfaces and cause eventual clogging of the barrier.

Manganese usually was $<5 \mathrm{mg} / \mathrm{L}$ within the barrier; however, at DP20S,M, D the concentration was between 28-44 mg/L, and at DP21D it was 7-23 mg/L. Magnesium was usually < $100 \mathrm{mg} / \mathrm{L}$ and was highest in DP21D at 27-112 mg/L. There is a possibility that $\mathrm{Mg}$ and $\mathrm{Mn}$ may form carbonate precipitates or coprecipitates with iron oxyhydroxides. The extent to which $\mathrm{Mg}$ and $\mathrm{Mn}$ mineral precipitate formation impacts performance of the iron barrier is still a matter of debate.

\subsection{HEAVY METALS}

Heavy metals in the contaminated groundwater from Pathway 2 were also monitored although they are not the major contaminants of interest because of their low concentration. Cadmium, cobalt, chromium, copper and lead were mostly below detection limit, while nickel, zinc and strontium were present in low detectable amounts (Appendix A). Nickel concentrations were $<1 \mathrm{mg} / \mathrm{L}$ in all wells, with the majority of values $<0.5 \mathrm{mg} / \mathrm{L}$ (e.g., TMW11, TMW12, TMW13, DP8 - DP12, and some deep piezometers such as DP14D, DP15D, DP19-D21D). Zinc concentrations were generally $<0.05 \mathrm{mg} / \mathrm{L}$. Strontium contents were usually $<1 \mathrm{mg} / \mathrm{L}$, except in down gradient DP15D, where it increased to $3.28 \mathrm{mg} / \mathrm{L}$. Data is insufficient to determine whether the iron barrier is removing any of these heavy metals.

\subsection{ALUMINUM AND SILICON}

Aluminum was generally below detection limits $(<0.15 \mathrm{mg} / \mathrm{L})$ in groundwater except in the first couple of sampling intervals, perhaps due to the presence of fine Al-bearing mineral particles from the disturbance caused by the trench excavation. The highest values were observed in the downgradient wells DP7 (16.4 $\mathrm{mg} / \mathrm{L})$ and TPB7 $(27.26 \mathrm{mg} / \mathrm{L})$ and the upgradient well DP13 $(23 \mathrm{mg} / \mathrm{L})$ for the 3/6/98 sampling interval (Appendix A). Silica was present in low detectable amounts of generally $<0.5 \mathrm{mg} / \mathrm{L}$ with the highest values of $<10 \mathrm{mg} / \mathrm{L}$. Groundwater samples collected from downgradient wells DP8 (3.58-6.71 mg/L), DP9 (4.628.15), DP10 (3.94-6.4 mg/L), and Seeps 4 (4.94-7.04 mg/L) and $5(6.44 \mathrm{mg} / \mathrm{L})$ had the highest values. Aluminum and silicon are not expected to have a significant impact on the iron barriers except that they may be present in the iron filings as impurities or as aluminosilicate mineral colloids (clays) accumulated in the iron barrier. A small amount of silica appears to be removed in the barrier based on the decrease in silica concentration between upgradient well TMW11 and downgradient well TMW7.

\subsection{FIELD PARAMETERS}

The general distribution of field parameters such as $\mathrm{pH}$, Eh, and specific conductance are still similar to what is shown in the 1999 Milestone report (Watson et. al., 1999). The $\mathrm{pH}$ of the groundwater within the barrier generally increased from upgradient to downgradient locations with the highest $\mathrm{pH}$ being found in the middle of the $\mathrm{Fe}^{0}$ filings. A significant increase in $\mathrm{pH}$ occurs between TMW9 (middle of the Fe filings) and TMW11 (up gradient) and TMW7 (down gradient) on the edge of the Fe filing and pea gravel portion of the trench (Fig. 5.8, Appendix A). pH has risen steadily from 6.8 to >9 from April 1999 to January 2000 in TMW7. TMW9 has experienced a decline in $\mathrm{pH}$ from 9.5 in November 1999 to 8.5 to 9 thereafter. The $\mathrm{pH}$ values have similar trends to specific conductance and $\mathrm{Ca}$ within the $\mathrm{Fe}^{0}$ portion of the barrier (Fig. 5.8 and Appendix A) suggesting a relationship of lower dissolved solids content and Ca concentrations and precipitation of solids with high $\mathrm{pH}$ and an increase in reducing conditions. Inversely, the redox potential (Eh) 
is generally lowest in the middle of the trench where the highest reducing conditions exist (Fig 5.9). Well TMW7 has similar but slightly higher Eh values compared to TMW9. As can be expected, the highest Eh values are observed in the up gradient well, TMW12, where the conditions are not reducing. Since November 1998 the Eh values for TMW11 has risen greatly and since the February 1998 sampling is now similar to the background well TMW12. 


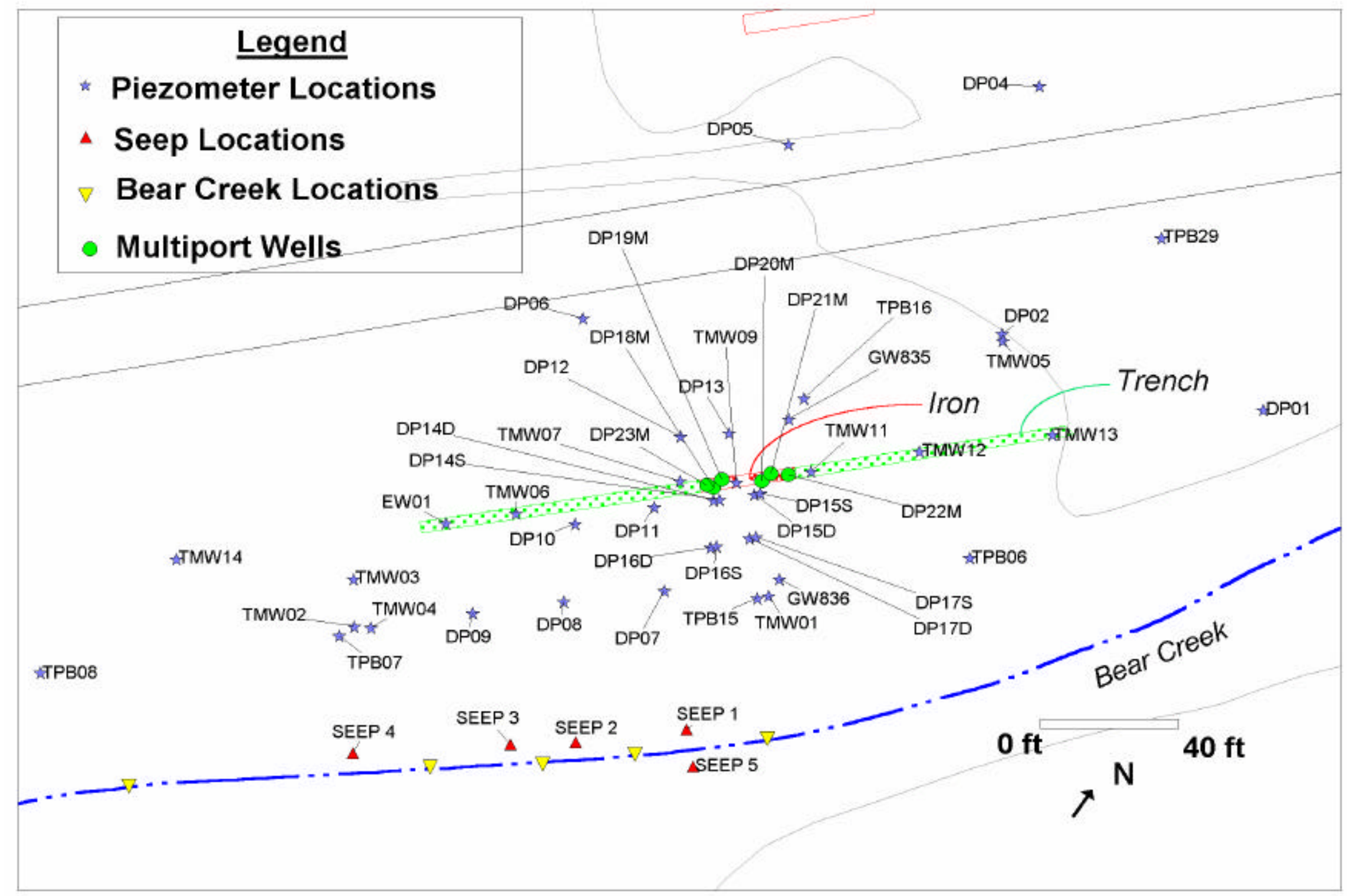

Fig. 5.1. Monitoring locations at Pathway 2 Permeable Reactive Barrier 


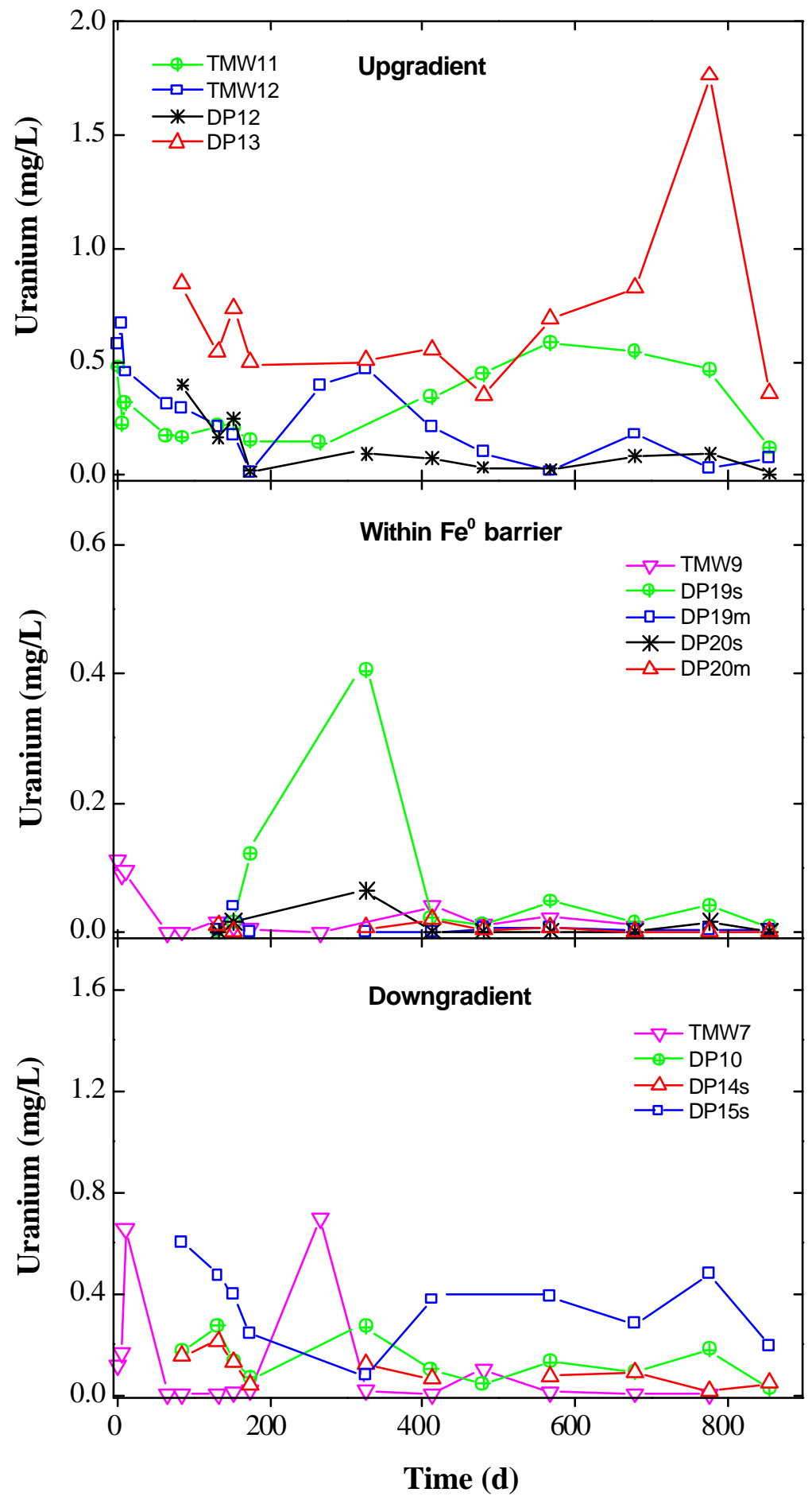

Fig 5.2. Uranium concentration profiles in some selected monitoring wells or piezometers within and in vicinity of the $\mathrm{Fe}^{0}$ reactive barrier at the Oak Ridge Y-12 site. 


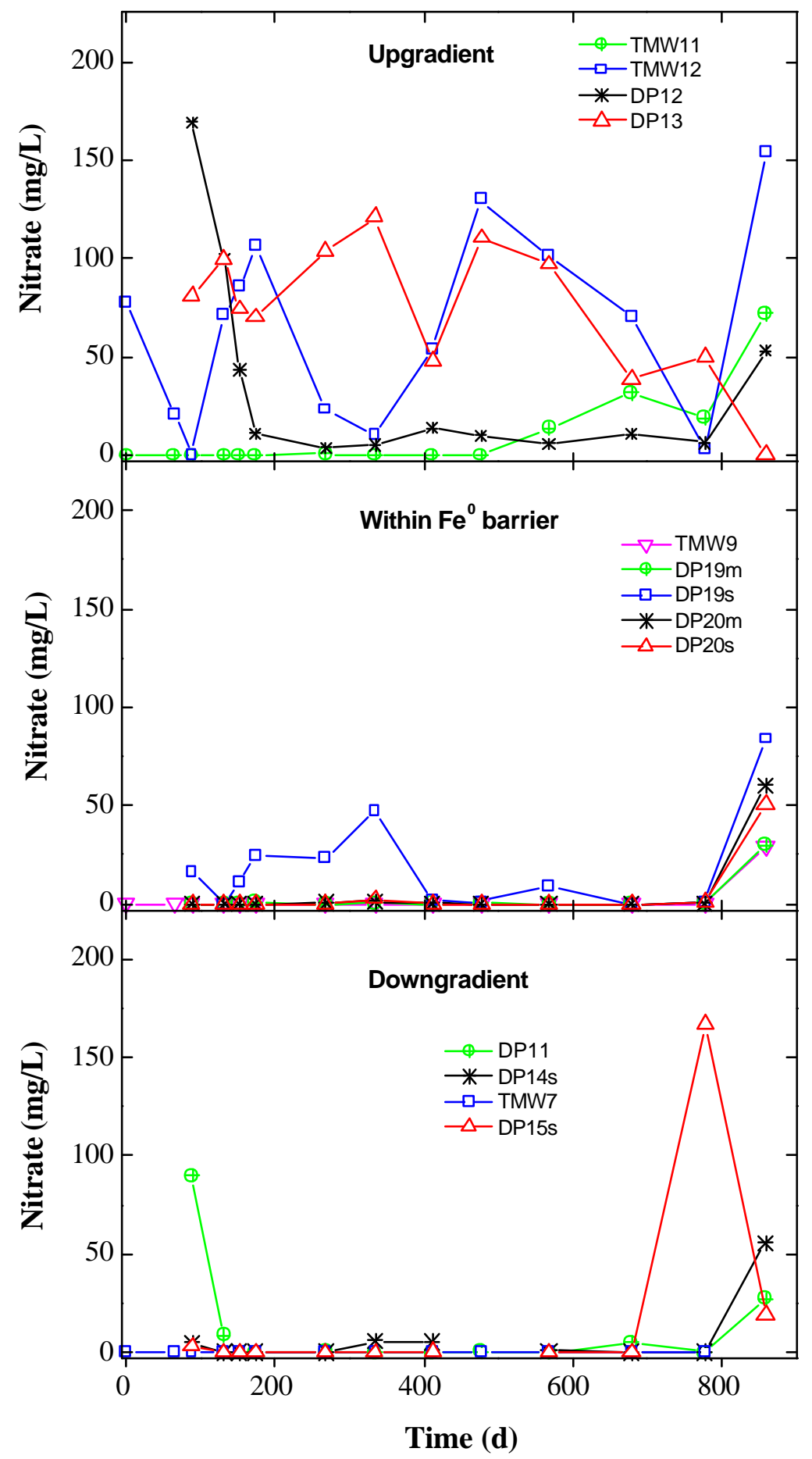

Fig 5.3. Nitrate concentration profiles in some selected monitoring wells or piezometers within and in vicinity of the $\mathrm{Fe}^{0}$ reactive barrier at the Oak Ridge Y-12 site. 


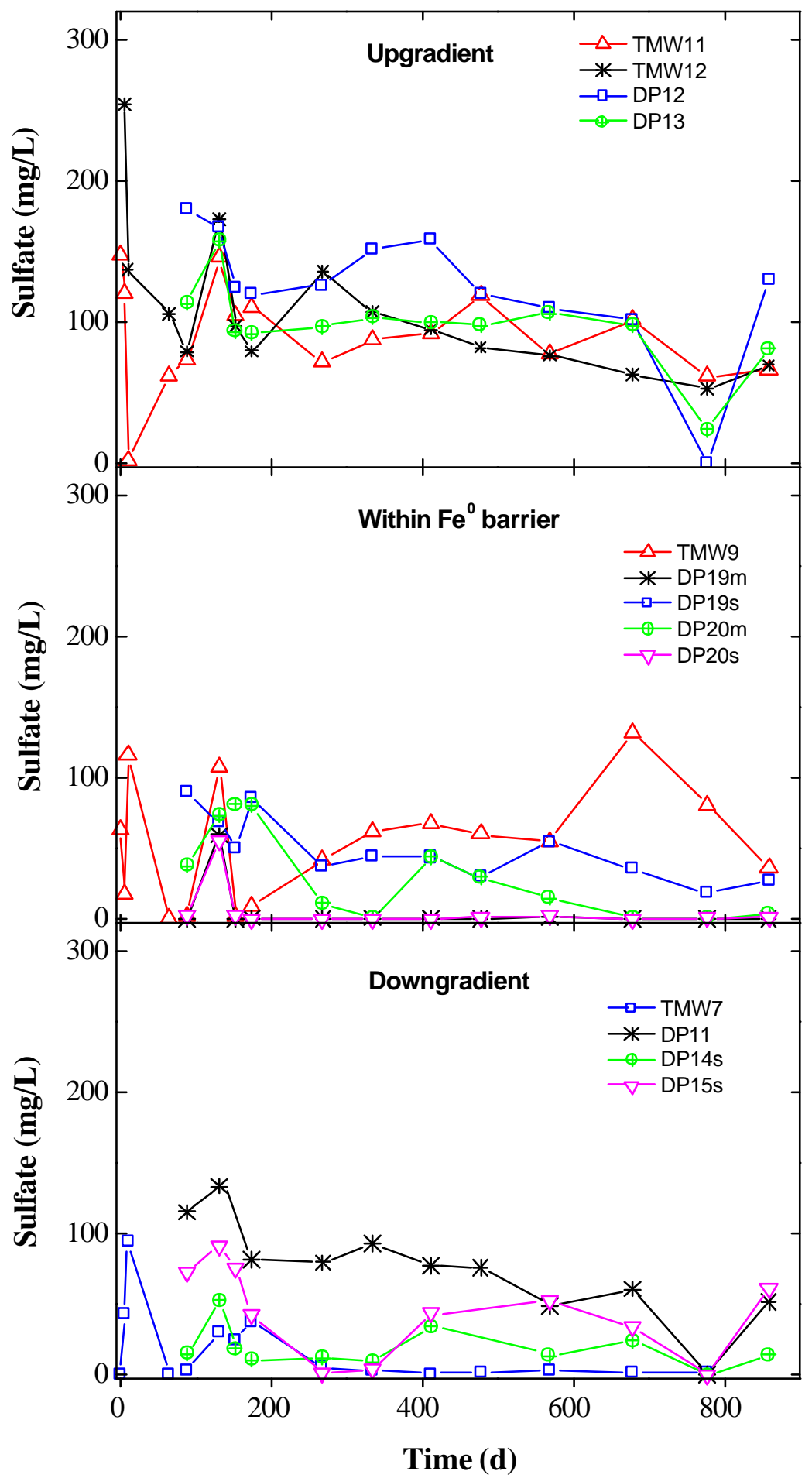

Fig 5.4. Sulfate concentration profiles in some selected monitoring wells or piezometers within and in vicinity of the $\mathrm{Fe}^{0}$ reactive barrier at the Oak Ridge Y-12 site. 


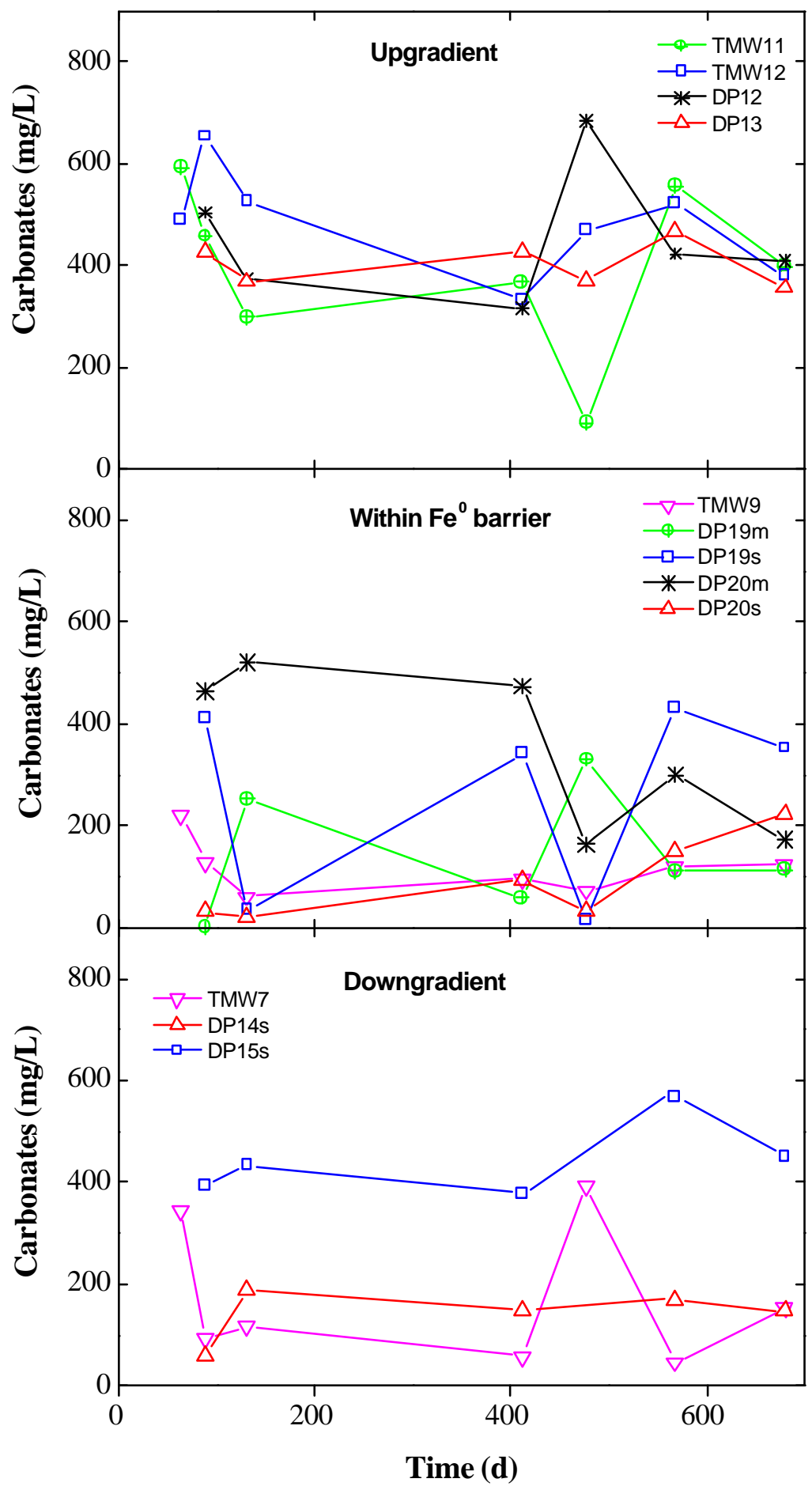

Fig 5.5. Carbonate/bicarbonate concentration profiles in some selected monitoring wells or piezometers within and in vicinity of the $\mathrm{Fe}^{0}$ reactive barrier at the Oak Ridge Y-12 site. 


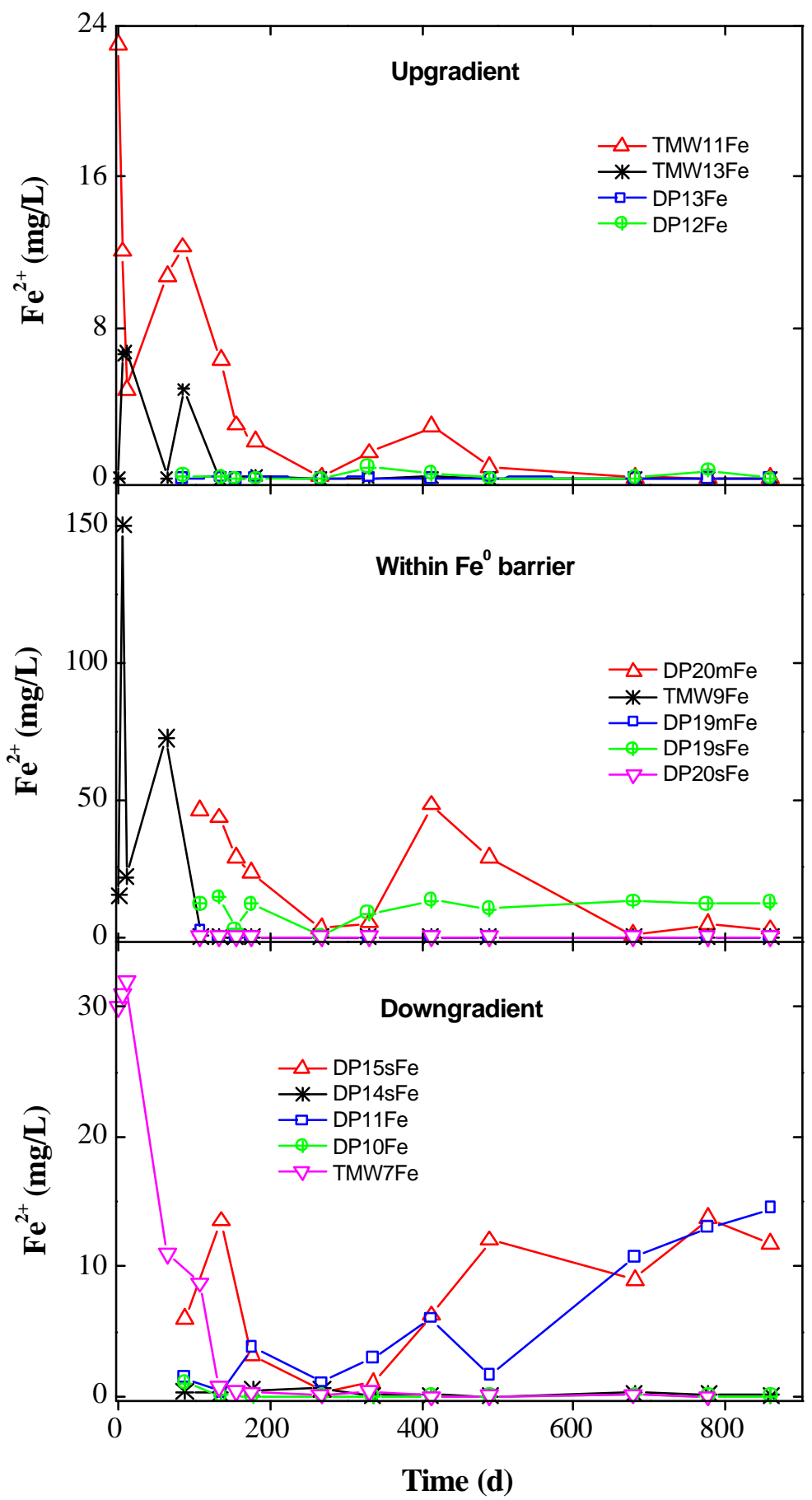

Fig 5.6. Ferrous ion concentration in some selected monitoring wells or piezometers within and in vicinity of the $\mathrm{Fe}^{0}$ reactive barrier at the Oak Ridge Y-12 site. 


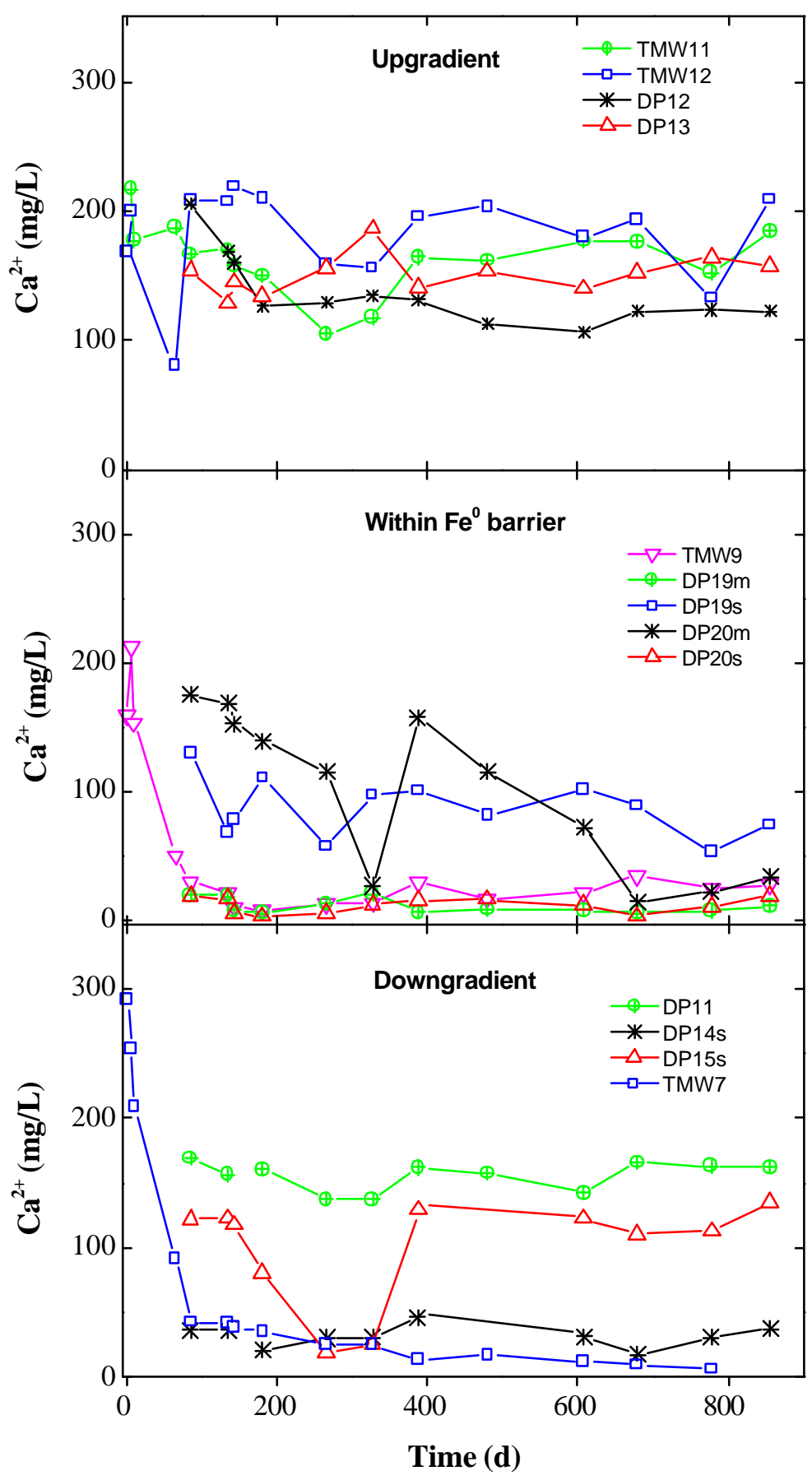

Fig 5.7. Calcium concentration profiles in some selected monitoring wells or piezometers within and in vicinity of the $\mathrm{Fe}^{0}$ reactive barrier at the Oak Ridge Y-12 site. 


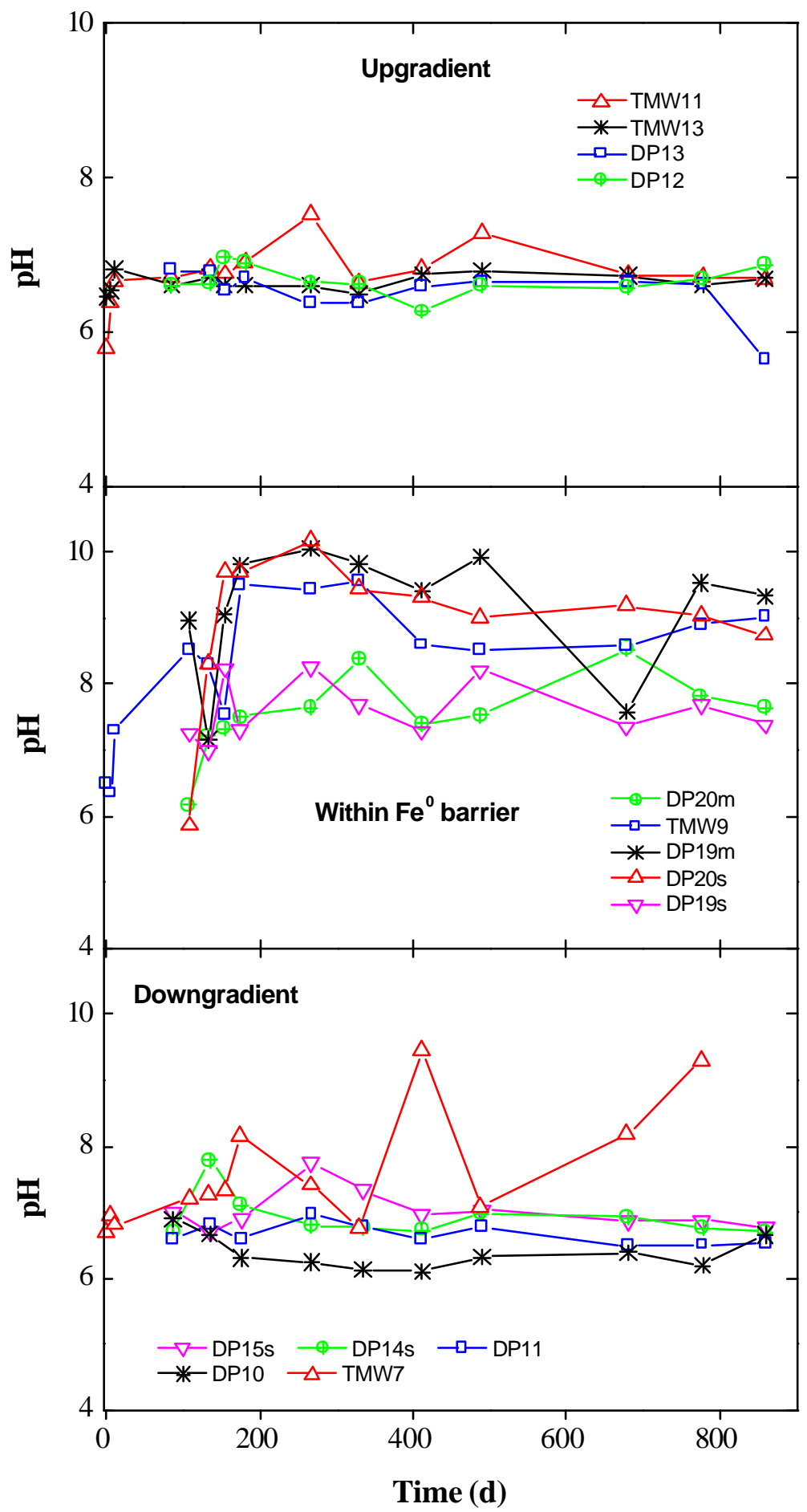

Fig 5.8. Groundwater $\mathrm{pH}$ in some selected monitoring wells or piezometers within and in vicinity of the $\mathrm{Fe}^{0}$ reactive barrier at the Oak Ridge Y-12 site. 


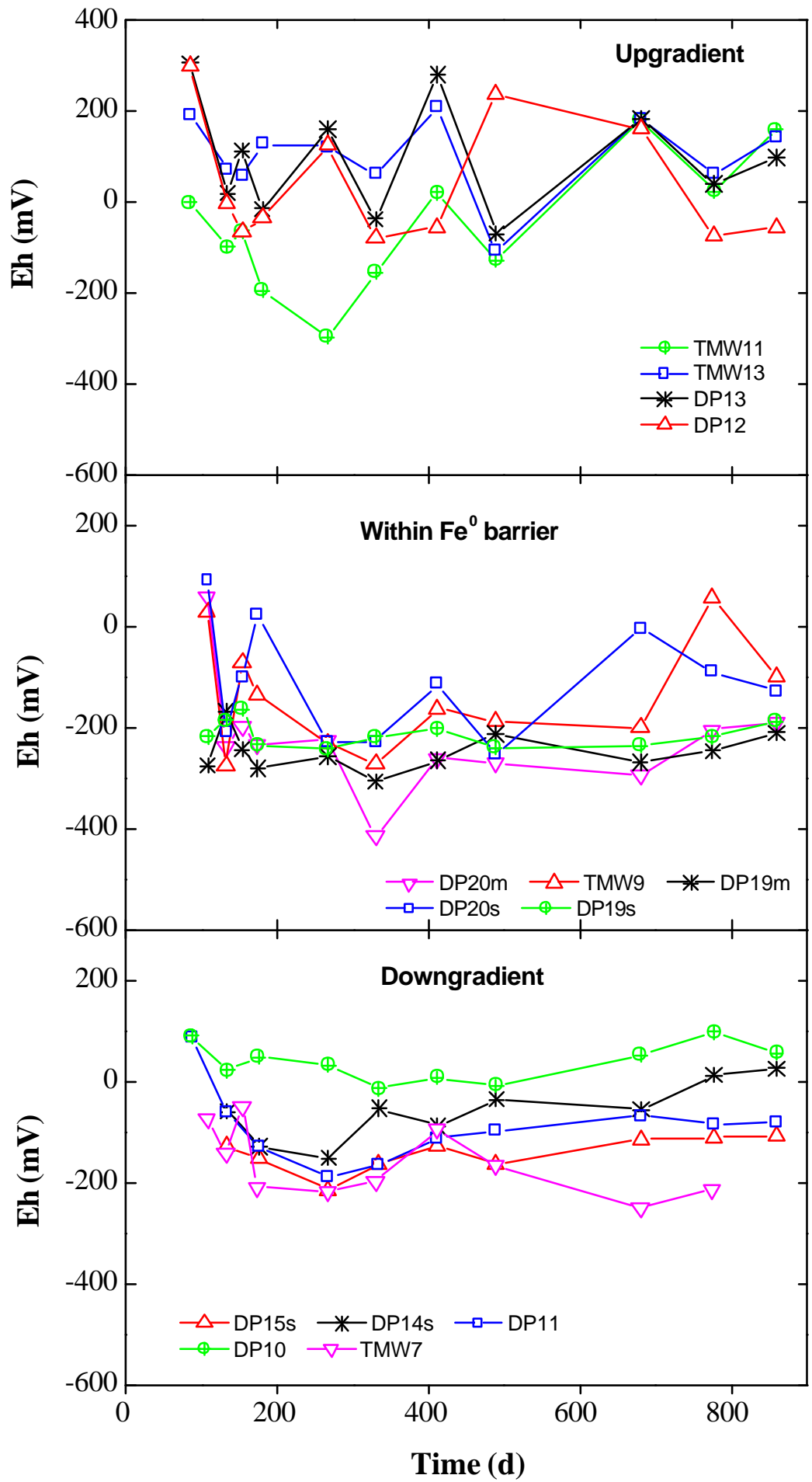

Fig 5.9. Groundwater Eh in some selected monitoring wells or piezometers within and in vicinity of the $\mathrm{Fe}^{0}$ reactive barrier at the Oak Ridge Y-12 site. 


\section{RESULTS OF CORE SAMPLE ANALYSIS}

\subsection{CORE COLLECTION}

In May 2000, almost 3 years after installation, cores were collected for the second time from the Y-12 iron barrier and adjacent fill material (Fig. 6.1a). The cores were taken from two sections (Fans) along the barrier at shallow ( 15-21') and deep ( 21-27') levels. The core locations are shown on Fig 6.2. The up and downgradient interfaces of the barrier and soil/fill material were intercepted by coring at 60 degree angles. This was accomplished by driving a hollow barrel through the fill material to the area of the barrier in which the cores were to be taken. One core was taken from each sampling point by driving the corer containing a polyurethane tube $(6 \mathrm{ft} \times 1.5$ in. dia.) through the hollow barrel into the barrier material (Figs. 6.1b, 6.3a,b). The polyurethane tube was cut to size and sealed with plastic caps immediately after they were removed from the barrier. Argon was injected into the cores through small incisions at each end of the plastic caps. These incisions were immediately sealed with tape after injection. The cores were stored in Ar purged airtight PVC tubes to minimize oxidation. During the period between sampling and preparation (1-3 weeks), the PVC storage tubes were purged with Ar twice a week.

Generally $\sim 3-4.5 \mathrm{ft}$ of core material and $\sim 2 \mathrm{ft}$ of up- and downgradient soil and fill material were collected in the tubes. Both up and down gradient interfaces were collected in a single core in order to avoid spillage and consequent mixing and loss of barrier material. During preparation, the trench material from each coring point was separated into 3-5 segments (usually $\sim 1 \mathrm{ft}$ in length).

\subsection{CORE MATERIAL}

Similar to the findings of the first cores taken in February 1999 (17 mo. after installation) (Phillips et al., 2000), after 3 years of burial under reduced conditions, the $\mathrm{Fe}^{0}$ filings and fine corrosion byproducts still appear black (reduced) and loose in most sections of the cores. However, cementation of barrier material appeared to be significantly greater in the May 2000 cores compared to the February 1999 cores.

As in the February. 1999 cores, clean contact between the $\mathrm{Fe}^{0}$ barrier and surrounding fill material (soil, rock fragments, and native bedrock) was observed in the May 2000 cores (Fig. 6.3b). Little to no mixing of surrounding soil/fill with the barrier material was observed; therefore, most of the mineral precipitates found in the barrier were formed in situ. Changes in geochemical environments within the $\mathrm{Fe}^{0}$ barrier are responsible for the formation of different mineralogies across the barrier, especially with depth (Figs. 6.46.7). A suite of minerals was detected by XRD and confirmed with SEM-EDX.

These minerals include $\alpha-, \beta$ - and $\gamma$ - iron oxyhydroxides, Fe and Ca carbonates, crystalline (makinawite) and amorphous FeS, maghemite/magnetite, lazurite and green rusts. Quartz was also detected by XRD throughout the core material.

\subsection{MINERAL PREICIPITATES}

Iron Oxyhydroxides and Oxides: There has been a striking change in the distribution of the FeOOH minerals since the last coring of February 1999. The 1999 core samples had akaganeite throughout the barrier and sporadic geothite, while the May 2000 cores seems to have a more defined distribution. The distribution of the FeOOH minerals may have been disturbed during the February 1999 core sampling event due to multiple sampling from a single $60^{\circ}$ angle core holes (mixing during retreval) (Phillips et al., 2000). 
Iron oxyhydroxides are very small minerals and are present as fine particles, which are easily suspended within the barrier. Additionally, slight changes in sampling location may have had an effect on these changes; however, the samples were collected very close to where the February 1999 samples were taken. During the May 2000 core sampling event single cores were collected which included both up- and downgradient interfaces in order to reduce sample mixing.

Fe oxyhydroxides, were detected by XRD throughout the cores collected from the barrier in May 2000 (Figs. 6.4-6.7). There appeared to be a trend in the occurrence of these oxyhydroxides with depth. Although there was difficulty in detecting akaganeite $(\beta-\mathrm{FeOOH})$ in most of these core samples, due to peak overlaps with other minerals especially quartz, it is thought that it occurs throughout the barrier. Akaganeite was detected throughout the February 1999 core samples (Phillips et al., 2000). Akaganeite has commonly been observed as a corrosion product of iron in chloride-containing surroundings, such as in marine environments (Refait and Genin, 1997). The formation of akaganeite may be related to a relatively high concentration of $\mathrm{Cl}^{-}$ content of the groundwater entering the trench (Fig. 6.8, 6.9, Appendix A). Chloride decreased in TMW9 within the barrier perhaps due to the precipitation of akaganeite. Chloride was generally lower in the $\mathrm{Fe}^{0}$ portion of the barrier compared to upgradient back-ground TMW12 (Fig. 6.9). In laboratory studies, akaganeite is commonly precipitated from $\mathrm{FeCl} 6 \mathrm{H}_{2} \mathrm{O}$. Chloride anions stabilize the structure of akaganeite and are reported to compose 1-7\% of this mineral (Schwertmann and Cornell, 1991). Geothite was present only in the shallow cores (15-21 ft) (Fig. 6.10). The reason for this distribution of FeOOH is probably related to an increase in oxidation in the shallow zone, compared to the deep zone, as observed by a general increase in Eh values in the shallow portion of the barrier since January 1999 (refer to Fig. 5.9). Some akaganeite may have also oxidized to geothite as reported by Schwertmann and Cornell (1991). Lepidocrosite $(\gamma-\mathrm{FeOOH})$ was observed sporadically throughout the shallow cores and deeper sections mainly where cementation was present. Lepidocrosite has also been reported in laboratory $\mathrm{Fe}^{0}$ column studies ( $\mathrm{Gu}$ et al., 1999).

Maghemite $\left(\gamma-\mathrm{Fe}^{+3}{ }_{2} \mathrm{O}_{3}\right) /$ magnetite $\left(\mathrm{Fe}^{+2} \mathrm{Fe}^{+3}{ }_{2} \mathrm{O}_{4}\right)$ was detected throughout the barrier by XRD (Figs. 6.46.7). Magnetite was originally present in the $\mathrm{Fe}^{0}$ filings (Roh et al., 2000), however, the XRD peaks of maghemite and magnetite are indistinguishable. Maghemite is usually an alteration product of magnetite. Some magnetites contain an excess of $\mathrm{Fe}_{2} \mathrm{O}_{3}$ and may grade towards the end-member maghemite. (Deer et al., 1983).

Green Rusts: Green rust was mainly detected by XRD in the deep portion of the barrier (21-27 ft). However, the morphology of what appears to be the $\mathrm{SO}_{4}^{-}$form of green rust $\left(\mathrm{SO}_{4}^{-}-\mathrm{GR}\right)$ was observed by SEM at a depth of 19-20 ft in the shallow portion of the barrier in Fan 1 (Fig. 6.11a-d), while the carbonate form $\left(\mathrm{CO}_{3}{ }^{-} \mathrm{GR}\right)$ was observed in the deeper section of the barrier. Green rust is unstable (Simons et al., 1997; Phillips et al., in review) and the less reduced environment of the shallow portion of the barrier may have hampered the formation or caused the disintegration of green rust below a detectable amount by the XRD analysis. Only small patches of green rust were observed by SEM in the February 1999 core samples and not detected by XRD. Researchers report that the precipitation of green rust is a useful component of reactive barrier systems in the remediation of contaminants (Erbs et al., 1999; Gu et al., 1999).

Sulfides and Sulfates: Crystalline (makinawite) and amorphous FeS was detected by XRD and SEMEDX across the shallow zone of the barrier (Figs. 6.12a-d, 6.13a-d). However, there appeared to be a decrease in amorphous FeS compared to findings of the February 1999 cores. Makinawite as detected mainly in the shallow zone and in the deep sections where cementation or greater oxidation occurred. Perhaps much of the amorphous FeS observed last year crystallized into makinawite. Makinawite was not detected in the February 1999 core material (Phillips et al., 2000). Amorphous FeS is still observed as bytrodial or rounded shaped formations and coatings in the barrier. Spirical precipitates (Figs. 6.13a-d) with ridged surfaces observed under high magnification are thought to be the crystallized form of the FeS (makinawite). 
Similar to last years findings, precipitation of $\mathrm{Fe}^{2+}$ with $\mathrm{S}^{2-}$, which forms $\mathrm{FeS}$ as well as other iron oxyhydroxides, has resulted in the depletion of $\mathrm{Fe}^{2+}$ from the $\mathrm{Fe}^{0}$ filing portion of the barrier. Low $\mathrm{Fe}^{2+}$ groundwater values are observed for TMW12, TMW6 and most of the peizometers within the $\mathrm{Fe}^{0}$ portion of the barrier where the groundwater conditions are favorable to oxidation (see Fig. 5.6). At DP22S, $\mathrm{Fe}^{2+}$ increased sharply in January 99 and has remained higher than previous concentrations (refer to Fig. 5.6).

A series of XRD peaks that form a good match with lazurite $(\mathrm{Na}, \mathrm{Ca})_{8}\left(\mathrm{AlSiO}_{4}\right)_{6}\left(\mathrm{SO}_{4}, \mathrm{~S}, \mathrm{Cl}\right)_{2}$ was also observed for core material throughout the barrier (Figs. 6.4-6.7). Lazurite is associated with pyrite (Klein and Hurlbut, 1977).

Calcium and Iron Carbonates: Aragonite $\left(\mathrm{CaCO}_{3}\right)$ crystals were observed by SEM-EDX and detected by XRD throughout the cores taken from the barrier (Figs. 6.4-6.7, 6.11a). Aragonite was also present in the deep core of Fan 2 near where it was not present last year in Fan C (Phillips et al., 2000). Additionally, calcite $\left(\mathrm{CaCO}_{3}\right)$ was also detected sporadically throughout the May 2000 core material.

The groundwater at the S-3 site contained both high Ca and bicarbonate concentrations because of the presence of Ca-rich bedrock, calcareous Nolichucky shale, strong nitric acid leachate from the S-3 ponds, and from the neutralization of the acid by limestone in 1984. Groundwater data from the wells in the trench shows that Ca content decreases dramatically from the upgradient pea gravel (TMW12) to the pea gravel at the edge of the barrier (TMW7) and in midsection of the $\mathrm{Fe}^{0}$ filings (TMW9) (refer to Fig. 5.7). This is because a great portion of the $\mathrm{Ca}$ in the groundwater precipitates into $\mathrm{CaCO}_{3}$ upon entering the trench. Additionally, piezometer data also shows that the $\mathrm{Ca}$ content varies with depth along the $\mathrm{Fe}^{0}$ filing section of the trench (refer to Fig. 5.7). Upon entering the trench, the $\mathrm{Ca}$ in the groundwater generally appears to decrease in the shallow zone compared to the middle and deep zones according to samples from DP20 and 21. This data supports SEM-EDX analysis and observations of $\mathrm{CaCO}_{3}$ present in shallow and some middle zone compared to the deep zone. However, in the downgradient section of the trench at DP18, DP19 and DP23 the Ca content is much lower in the middle zone, because a large portion of the $\mathrm{Ca}$ in the groundwater has been precipitated. However, $\mathrm{CaCO}_{3}$ has been observed in the deep Fan 2 collected in May 2000 (near the location where the deep Fan C samples were extracted in February 1999). Aragonite was not observed in the February 1999 cores from this section of the barrier.

Siderite $\left(\mathrm{FeCO}_{3}\right)$ was also detected by XRD mainly in the upgradient cemented zones in the shallow portion of the barrier and in the deeper portions of the barrier in Fan 1 from 23-26.4' in and near cementation. Perhaps it is precipitated in the more oxidized environment within this barrier. As observed by SEM micrographs, this mineral has a cube shape. Bicarbonate contents from wells TMW7 and 09 are considerably lower because it has been precipitated into carbonate minerals, as illustrated previously. The higher content of groundwater $\mathrm{HCO}_{3}{ }^{-}$at DP22s and TMW11 near shallow Fan 1 and DP19s near shallow Fan 2 perhaps may have contributed to the formation of siderite at the upgradient shallow interfaces (Figs. 6.14a-d). As stated earlier, the formation of carbonate minerals within the iron barrier is undesirable but was fully expected considering the local groundwater geochemistry. They don't appear to adversely affect the removal of uranium and nitrate in the groundwater at the moment. However, their long-term effect on the performance of the iron barrier is still under investigation.

\subsection{CEMENTATION}

Continuous cementation of iron filings was observed in the shallow upgradient portions of Fans 1 and 2 ( $\sim 10$ in thick), the downgradient ( 4 in thick) interface of shallow Fan 1, and the deep downgradient interface of Fan 1 ( 4 in thick). Less continuous cementation was also observed in the midsection of shallow Fan 1 ( $\sim 10$ in thick). According to XRD and SEM-EDX analysis, the cementation is composed mainly of Fe 
oxides and oxyhydroxides (particularly goethite), siderite $\left(\mathrm{FeCO}_{3}\right)$ and with smaller amounts of aragonite $\left(\mathrm{CaCO}_{3}\right)$. Fig. 6.15 shows the shallow Fan 1 core material after processing (drying) and the distribution of most of the cemented material. Loose core material was recovered in the cemented zones. Based on the condition of the cementation from the interface zones (very hard and dense-had to be broken with a hammer) and XRD analysis (cementation has similar mineralogy as surrounding loose material), this loose material is thought to be artifacts ( $\mathrm{Fe}^{0}$ filings and precipitates loosened during coring). The cores collected in February 1999 showed cementation only in the shallow downgradient interface of Fan A (near Fan 1) and in the upgradient deep interface of Fan A (between $18-21 \mathrm{ft}$ deep). Continual formation of this cementation may eventually restrict the groundwater flow rate and pattern through the trench; thus, reducing the long-term performance of this $\mathrm{Fe}^{0}$ barrier to remove uranium and other contaminants.

There is a possibility that the increase in $\mathrm{Fe}^{2+}$ near the cementation zones in upgradient DP22s and downgradient DP23s since January 1999 indicates a chemical change that has brought on greater cementation (refer to Fig. 5.6).

\subsection{MICROBIAL ACTIVITY AND COMMUNITY COMPOSITION}

Selected groundwater samples and core samples were analyzed for microbial activity and population by both PLFA and specific DNA probe analyses. PLFA method is an important component of all cellular membranes that maintain cell fluidity enabling the transport of nutrients into the cell and elimination of metabolic byproducts. Analysis is based on the extraction and separation of lipids classes, followed by quantitative analysis by means of gas chromatography/mass spectroscopic techniques. PLFA provide a quantitative means to measure viable microbial biomass (in picomoles per $\mathrm{mL}$ of groundwater or picomoles per gram soil), community composition, and nutritional status, although it cannot provide information on specific bacterial strains which are present in the sample. Specific DNA probe analysis (based on polymerase chain reactions or PCR analysis), on the other hand, provides specific genes or DNA of a particular microorganism, as reported previously.

Results (Fig. 6.16) indicated that a variety of microbial population is present within and in the vicinity of the iron barrier in comparison with that of TMW5 groundwater (a background location $30 \mathrm{ft}$ upgradient of the trench). Low microbial activity $\left(<10^{4}\right.$ cells $\left./ \mathrm{mL}\right)$ was observed in TMW5, but a substantially enhanced microbial activity was observed within the iron barrier (TMW9 and DP20m) and in the downgradient soil (DP11). In addition, there appears a general trend that microbial activity increased from the upgradient iron barrier to the downgradient soil (Fig. 6.16). The PLFA analysis also indicated the presence of a variety of microbial communities in groundwater (Fig. 6.17) although PLFA analysis suffers from its inability to identify specific species of microorganisms because many microbial species have similar PLFA patterns. However, PLFA analysis is able to provide insights into microbial community composition because some specific groups of microorganisms contain characteristic fatty acid profiles or lipid biomarkers. Six general groups of microbial communities were classified on the basis of the following PLFA structural groups: terminallybranched, mid-chain branched, branched monoenoic, eukaryote, monoenoic, and normal saturated PLFAs. The first three groups are commonly found in Gram-positive and anaerobic microorganisms such as sulfateand metal-reducing bacteria, and some Gram-negative facultative anaerobes. The last three groups are found in most Gram-negative bacteria and some types of microeukaryotes. In particular, the monoenoic PLFA may represent fast-growing Gram-negative bacteria that can utilize a wide range of carbon sources and adapt quickly to a variety of environments.

Results (Fig. 6.17) indicated that these fast-growing Gram-negative bacteria (monoenoic PLFA) were among the most abundant found in all groundwater samples. In comparison with results obtained last year, 
no significant amount of eukaryotes were found in groundwater samples obtained in April 2000 (or $~ 2.5$ years after the iron barrier was installed). Note that eukaryotes are mostly found in organisms such as fungi, protozoa, algae, higher plants, and animals. In fact, some protozoa and higher animals were observed in groundwater by a colloidal borescope in December of 1998 (Watson et al. 1999).

Analysis of iron and soil core samples also revealed the presence of viable microbial populations in these samples (Figs. 6.18 and 6.19). In general, microbial biomass in the shallow iron/soil core samples was found to be $\sim 1-2$ orders of magnitude higher than those in the deep soil/iron core samples. The total microbial activity was also higher than those samples obtained in February 1999. Similarly as observed in groundwater samples, a diversified microbial population was observed in these soil/iron core samples (Fig. 6.19). Excluding samples from deep profiles (d-Fe and Down-d-soil), the Gram negative microbial population appeared to decrease from the upgradient soil to the downgradient soil/iron interface samples. On the other hand, the Gram positive microbial population increased consistently from the upgradient soil to the downgradient soil/iron interface samples.

Although no DNA probe analysis was performed in FY 00, sulfate-reducers, denitrifiers, and methanogens were all identified in both groundwater and cores samples of FY 99. In particular, the sulfate reducers and denitrifiers appear to be the most abundant in many of the samples except TMW5 (a background well). These results may support conclusions that a decreased sulfate concentration within the iron portion of the trench was a result of microbial reduction of sulfate to sulfide under anaerobic conditions (by $\mathrm{Fe}^{0}$ or guar gum initially). In other words, these microorganisms may have played a crucial role in the reduction of both sulfate and nitrate (as induced by a strong reducing environment by $\mathrm{Fe}^{0}$ corrosion) and in the formation of FeS precipitates in the iron barrier. 

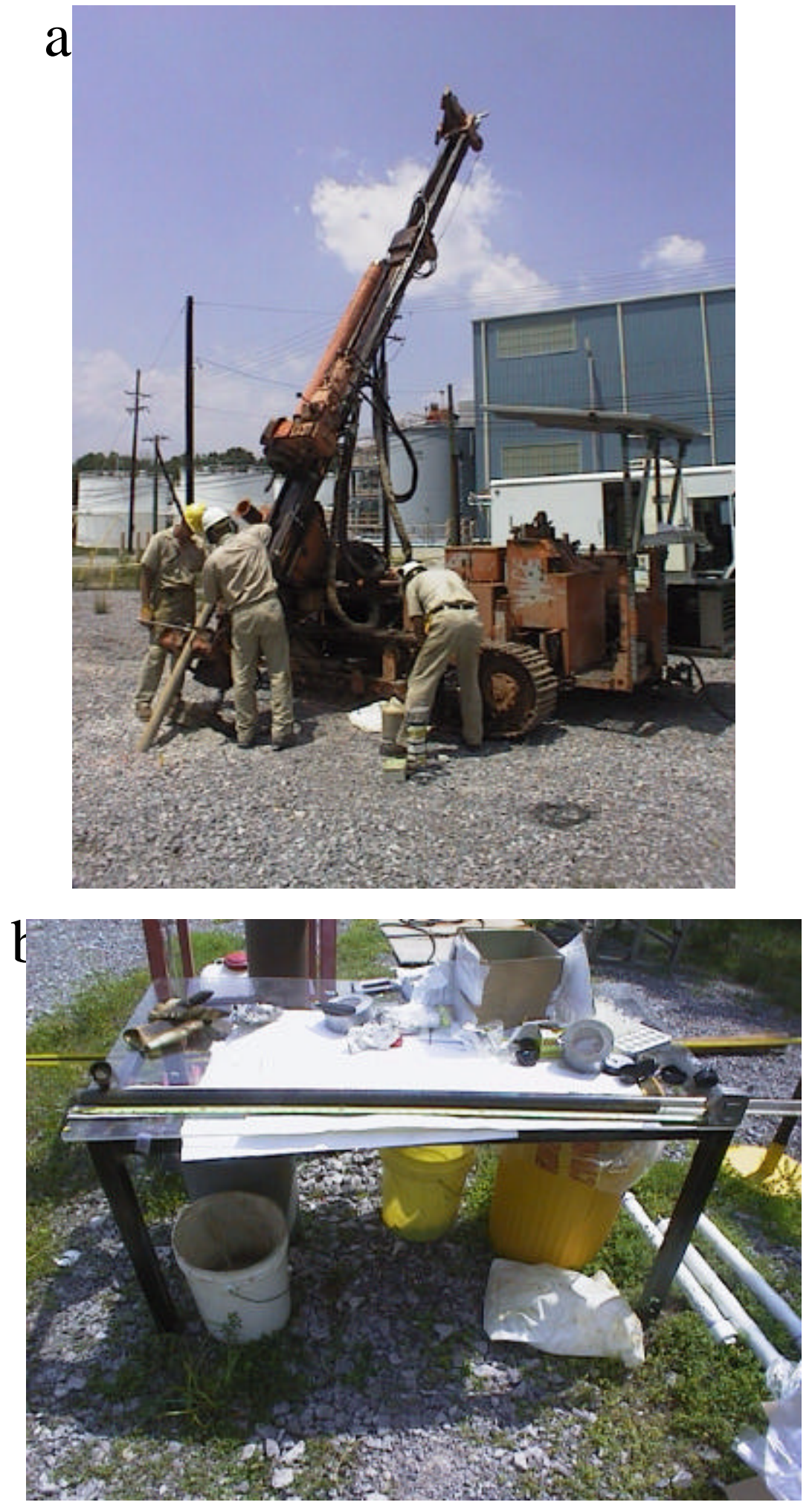

Fig. 6.1. a) The core drill at a $60^{\circ}$ angle, and b) a core in a polyurethane tube. 


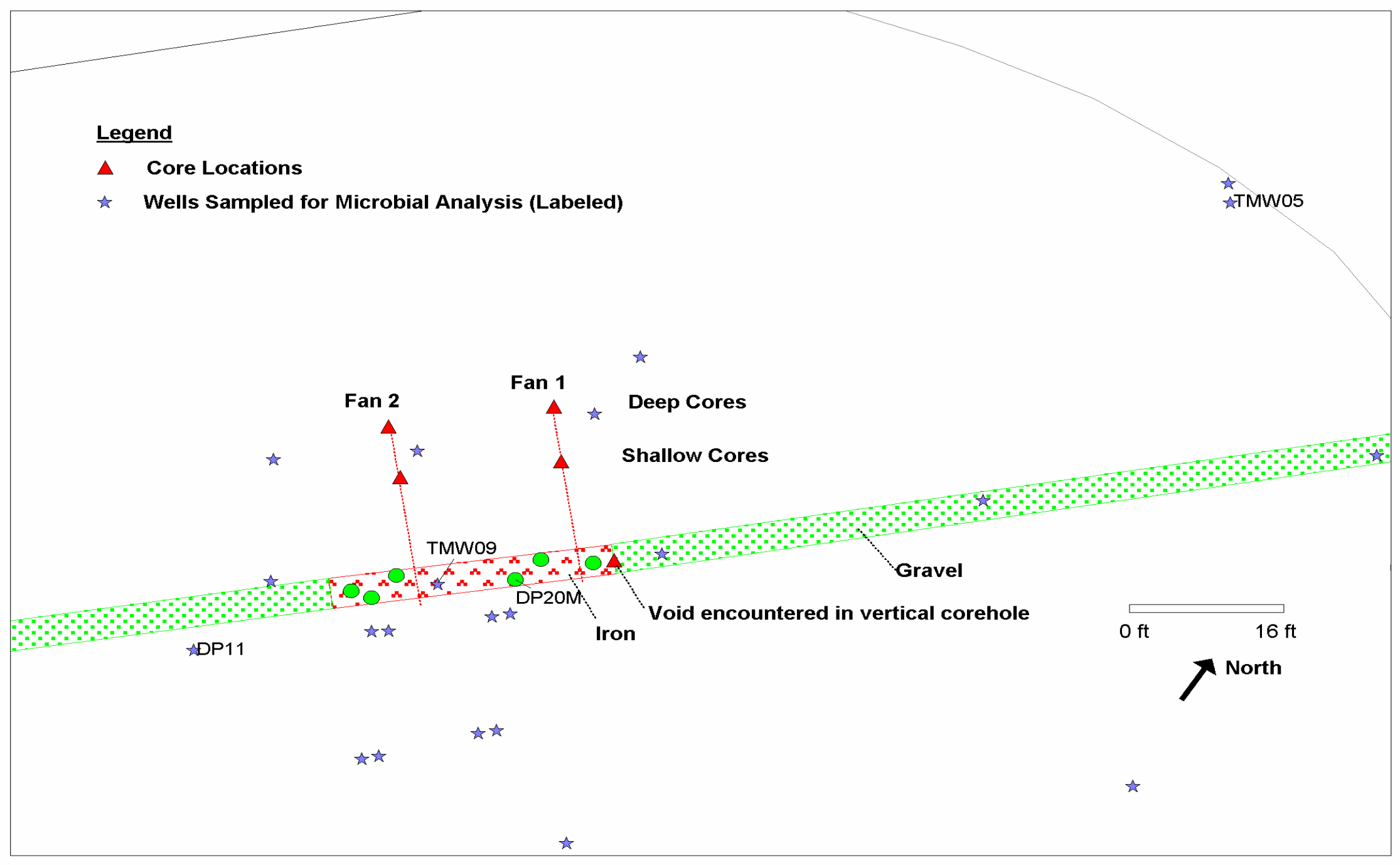

Fig 6.2. Location of cores collected at Pathway 2 trench June 2000 

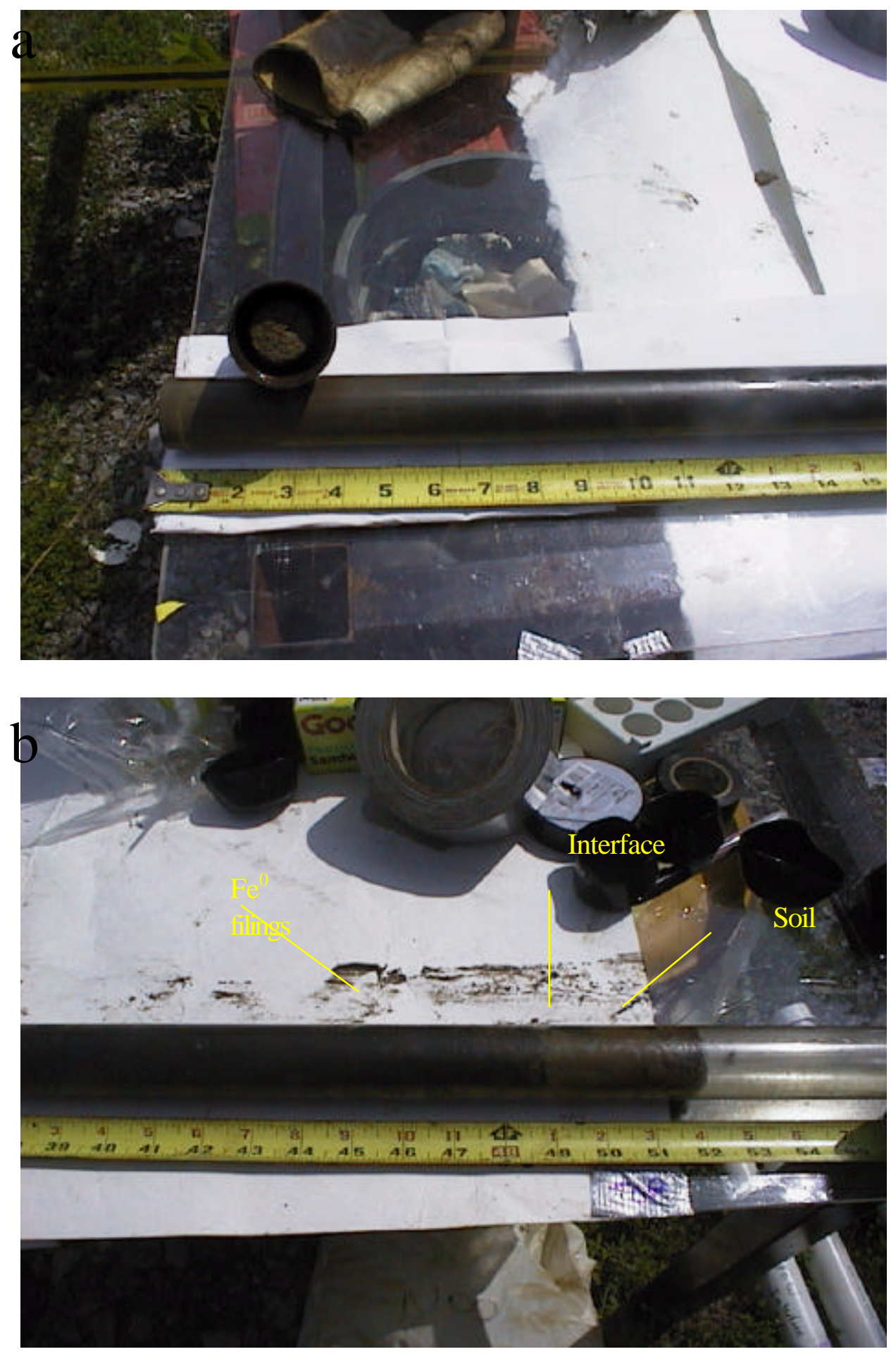

Fig. 6.3. a) A portion of the core and coring tube showing the diameter of the core, and b)the clean break at the interface between coring material and soil/fill material in a core. 


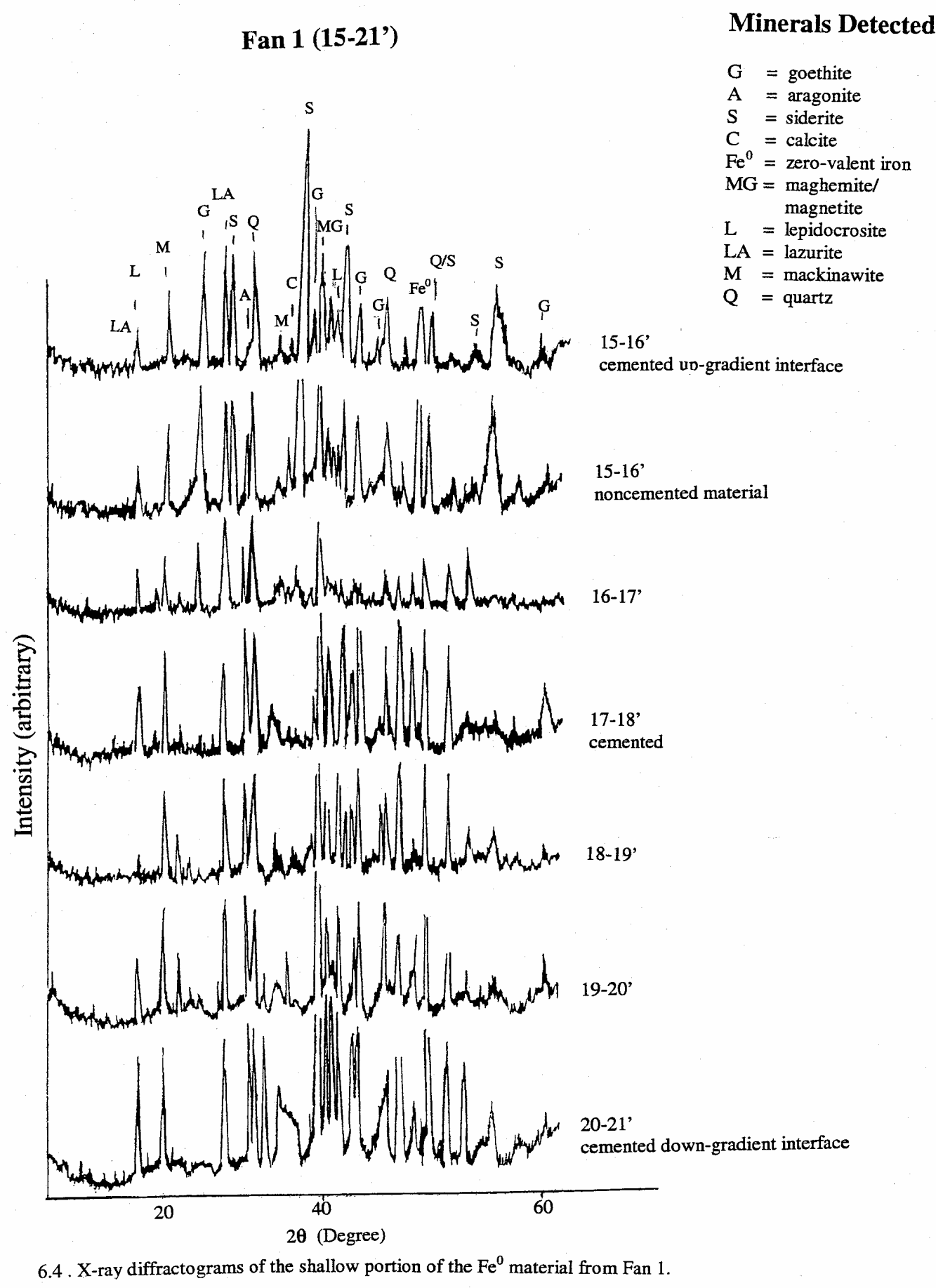


Fan 1 (21-27')

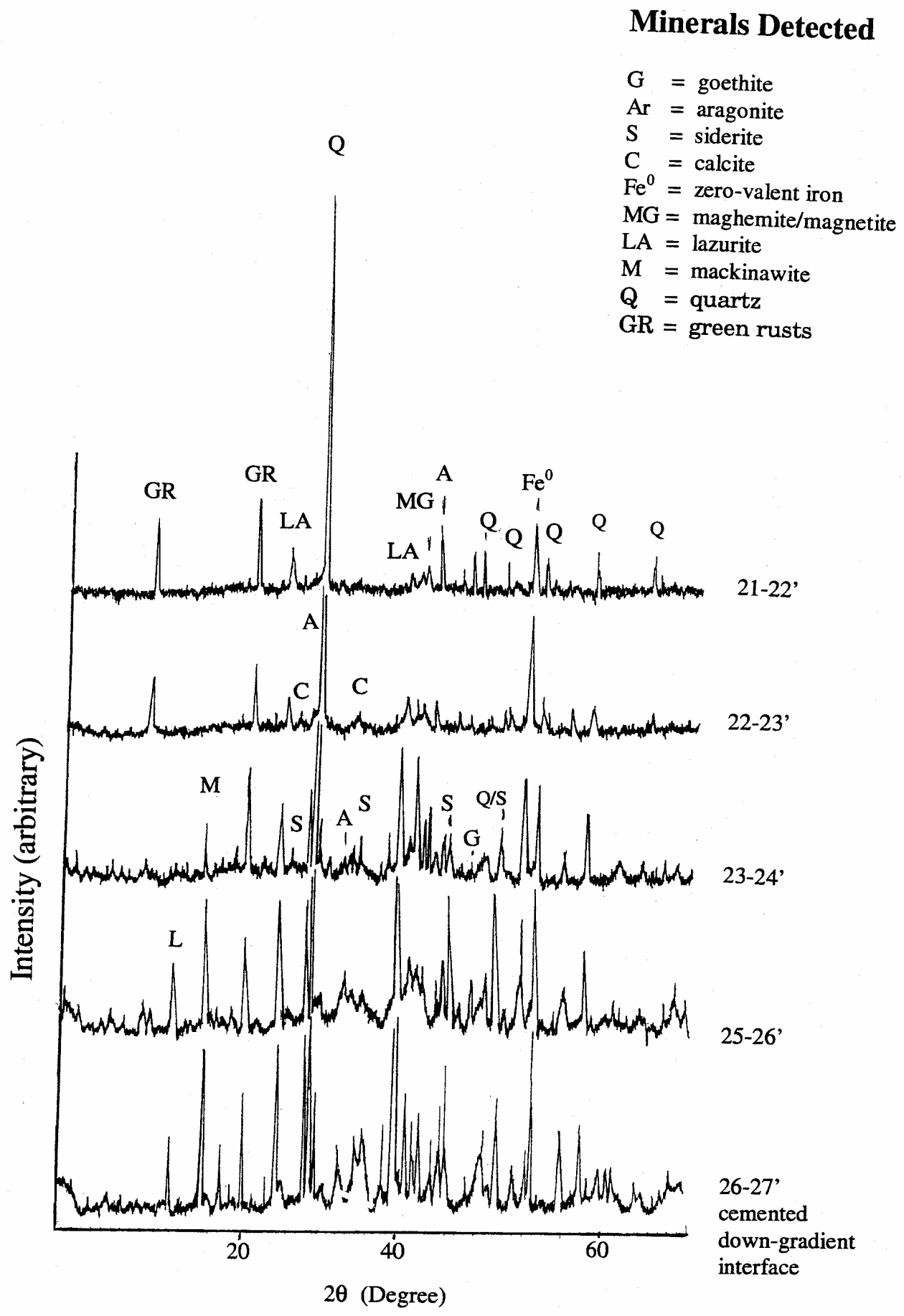

6.5. X-ray diffractograms of the deep portion of the $\mathrm{Fe}^{0}$ material from Fan 1. 
Fan 2 (15-21')

Minerals Detected

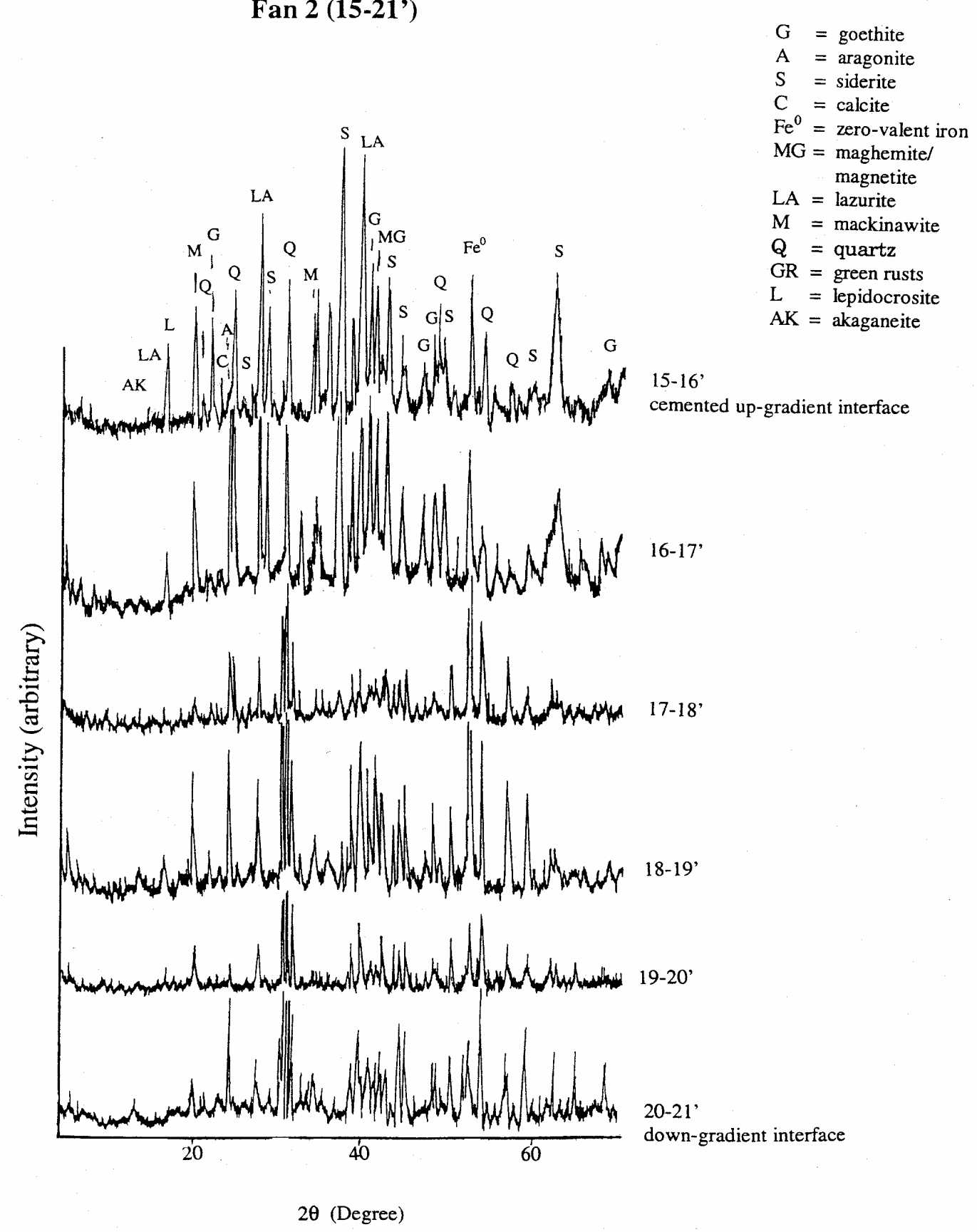

6.6. X-ray diffractograms of the shallow portion of the $\mathrm{Fe}^{0}$ material from Fan 2 . 
Fan 2 (21-27')

\section{Minerals Detected}

$$
\begin{aligned}
& \mathrm{Ar}=\text { aragonite } \\
& \mathrm{Fe}^{0}=\text { zero-valent iron } \\
& \mathrm{MG}=\text { maghemite/magnetite } \\
& \mathrm{LA}=\text { lazurite } \\
& \mathrm{M}=\text { mackinawite } \\
& \mathrm{Q}=\text { quartz } \\
& \mathrm{GR}=\text { green rusts } \\
& \mathrm{L}=\text { lepidocrosite }
\end{aligned}
$$

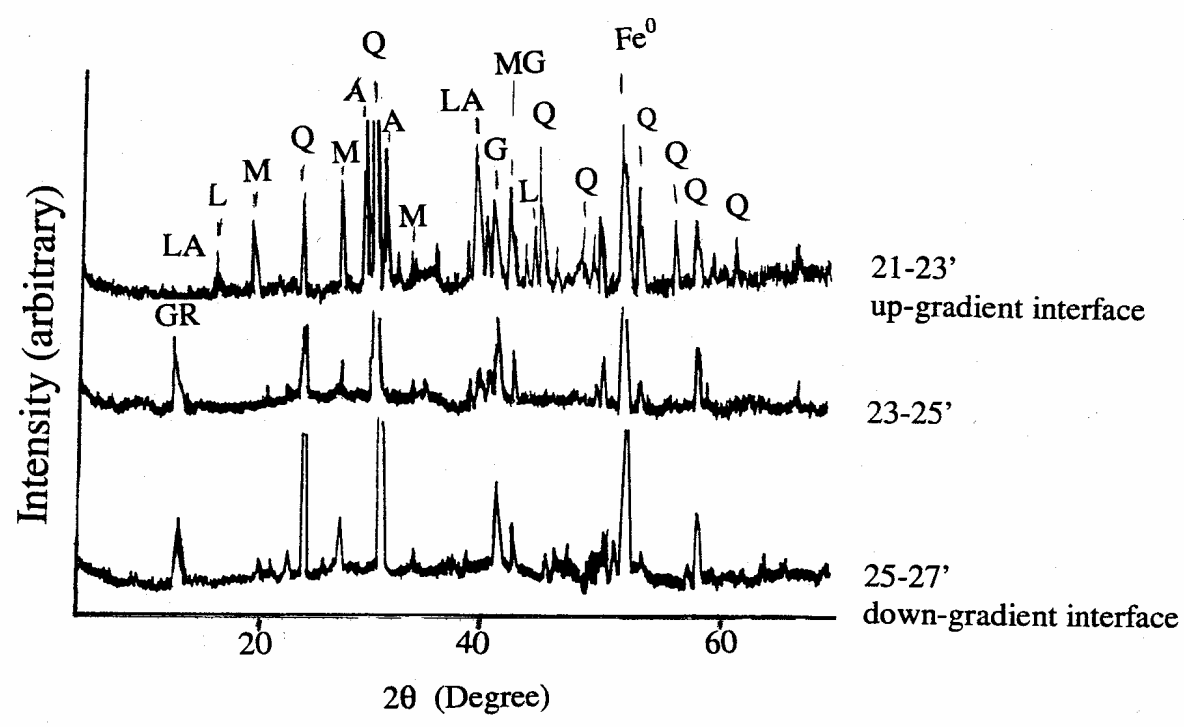

6.7. X-ray diffractograms of the deep portion of the $\mathrm{Fe}^{0}$ material from Fan 2 . 


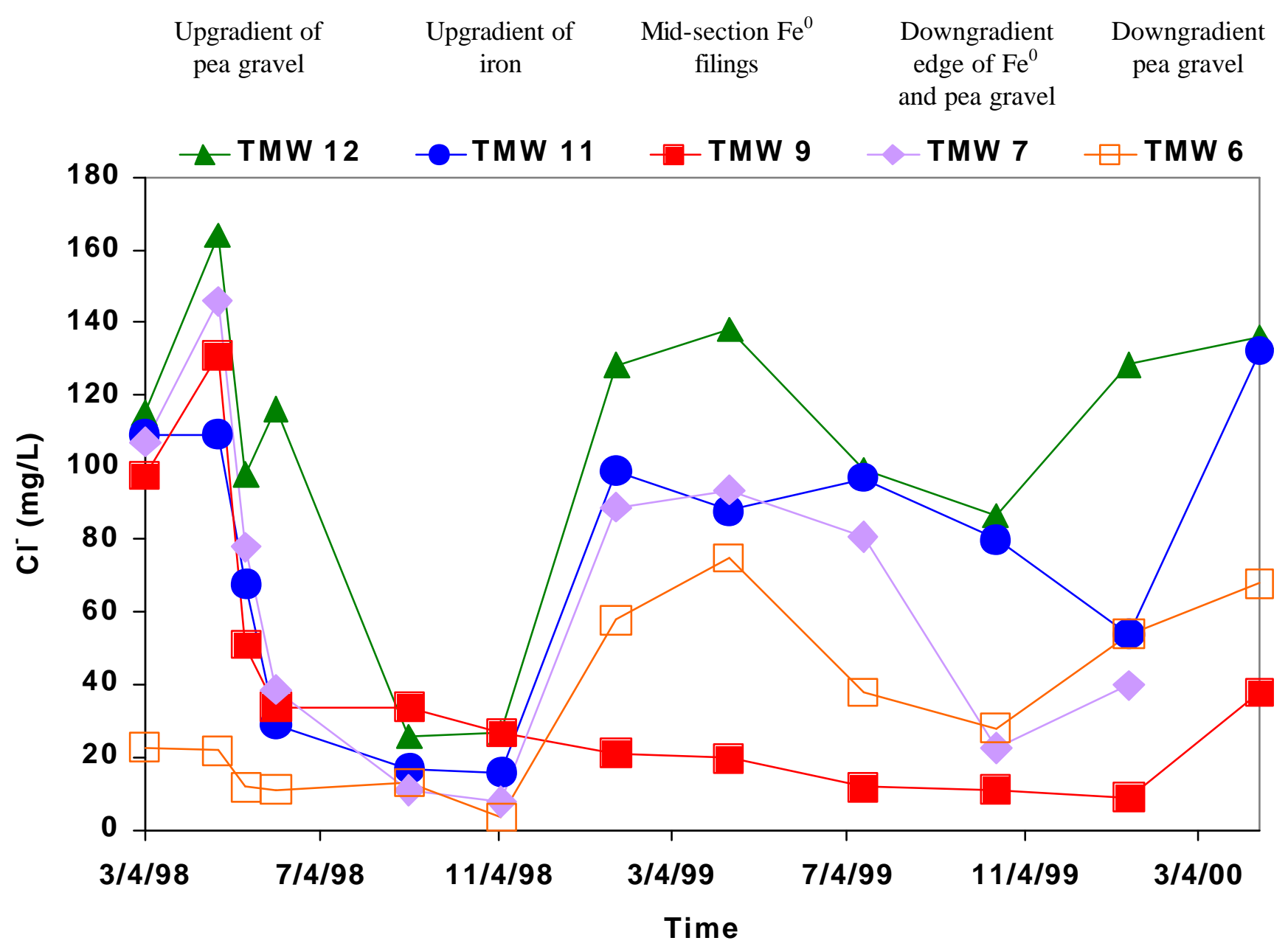

Fig. 6.8. Distribution of chloride within the barrier system. 


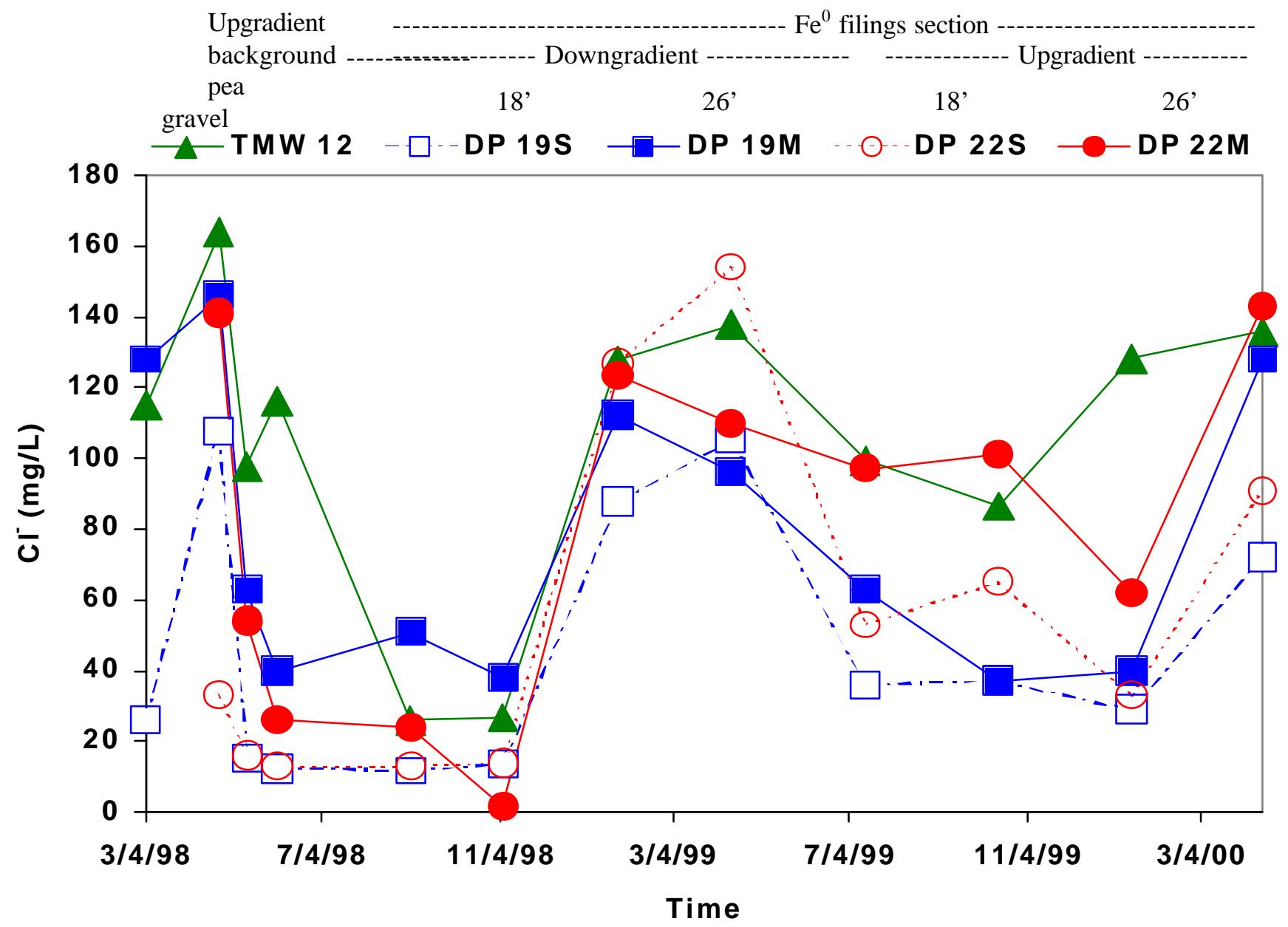

Fig. 6.9. Distribution of chloride within the $\mathrm{Fe}^{0}$ portion of the barrier. 

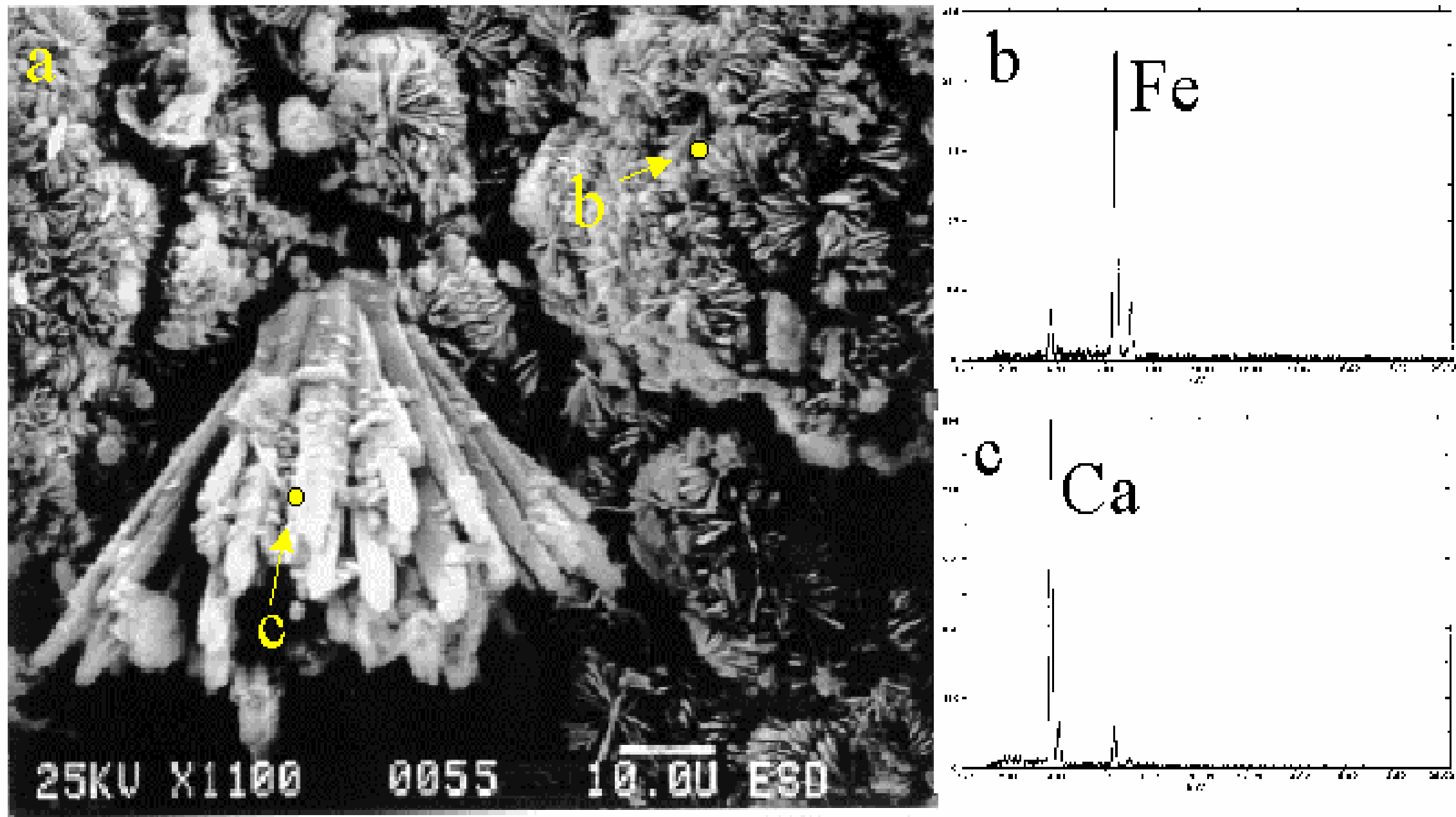

Fig. 6.10. a) Photomicrograph of geothite $(\alpha-\mathrm{FeOOH})$ and aragonite $\left(\mathrm{CaCO}_{3}\right)$ in shallow Fan 1 at $19-20 \mathrm{ft}$, b) SEM-EDX of an area of the geothite, and c) SEM-EDX of an area of the aragonite. 

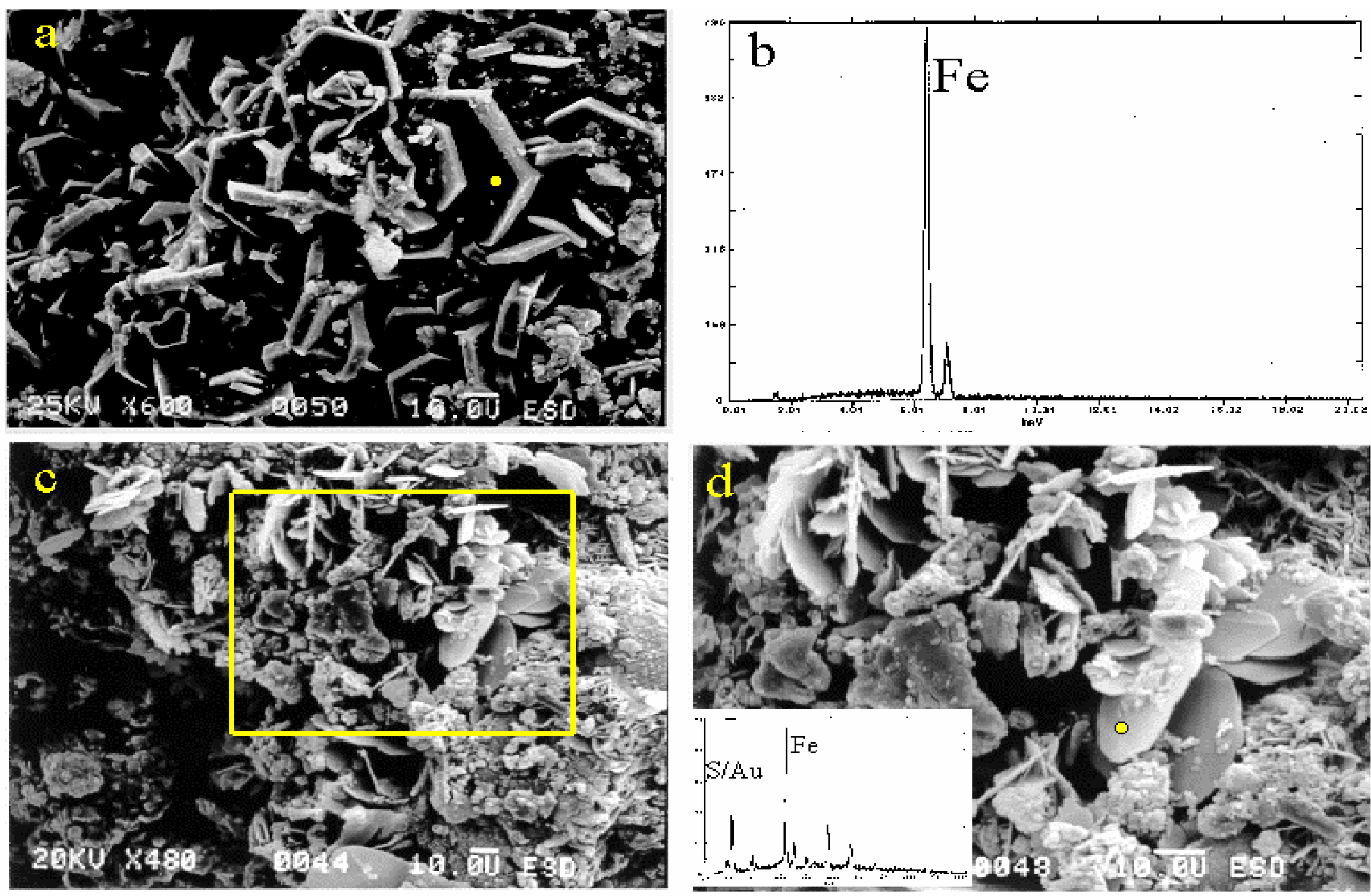

Fig. 6.11. Photomicrographs of green rusts from the barrier. a) carbonate form of green rust showing the euhedral he xagonal form from the deep downgradient inte rface of Fan 2 at $26-27 \mathrm{ft}$, b) SEM-EDX of the green rusts from (a), c) the sulfate form of green rust from the shallow zone of Fan 1 from $19-20$ $\mathrm{ft}$, d) enlarge ment of an area from ( c). 

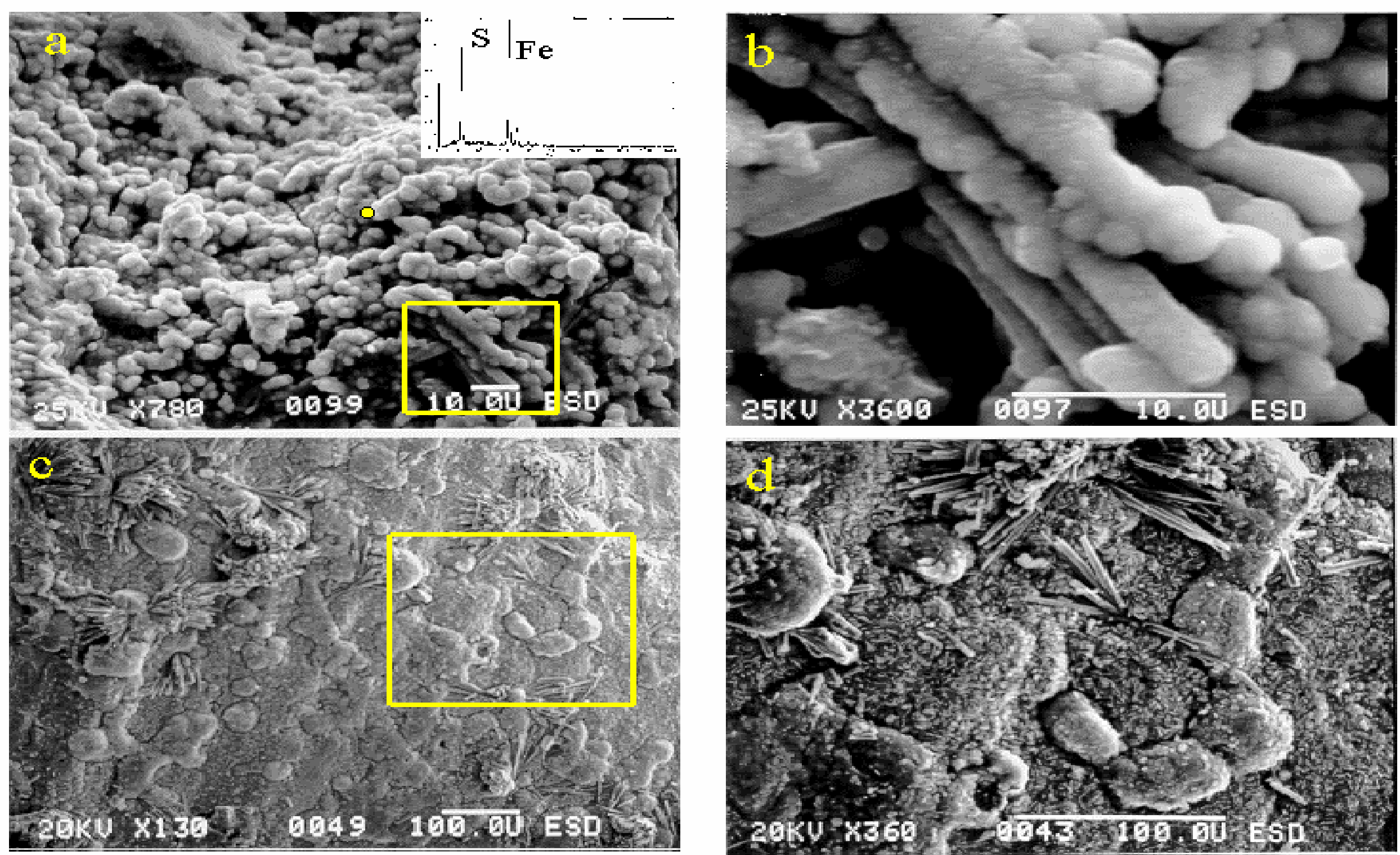

Fig.6.12. Photomicrographs of amorphous $\mathrm{FeS}$ in the barrier. a) the rounded or bytrodial amorphous $\mathrm{FeS}$ coating material on a Fe filing from the shallo. section of Fan 1 in the cerme nted zone at $17-18 \mathrm{ft}$, c) enlargement of an area of (a) showing $F e S$ coatings on aragonite crystals, c) amorphous FeS are rour globules on an $\mathrm{Fe}^{0}$ filing surface from $18-19 \mathrm{ft}$ in the shallow section of Fan 2, d) enlarge ment of an area of (c) thowing the round globules. 

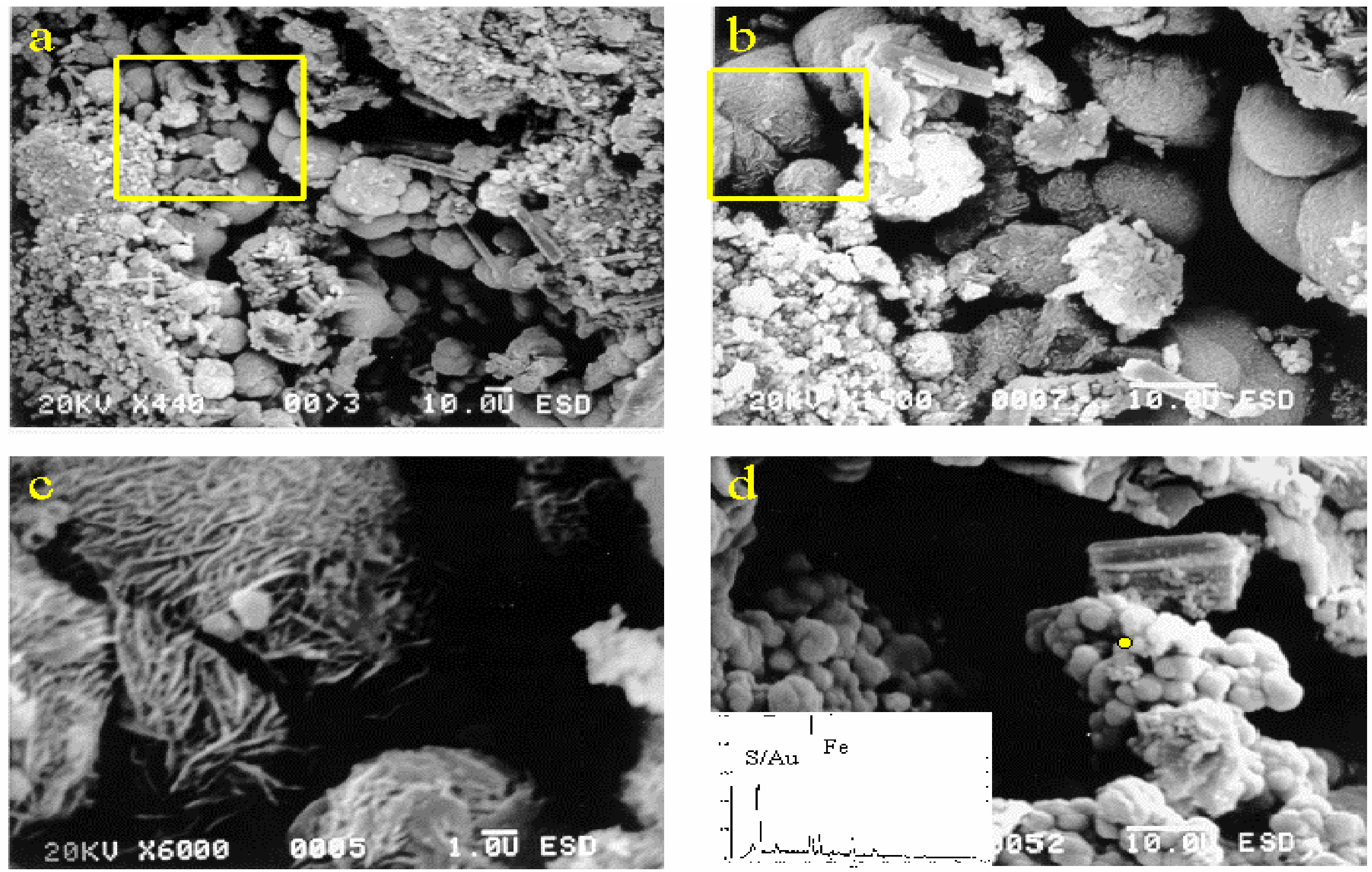

Fig. 6.13. Photomic rographs of crystalline $\mathrm{FeS}$ from the barrier. a) sphe rical precipitates thought to be makinawite on an $\mathrm{Fe}{ }^{0}$ filing from the shallow zone of Fan 2 at $20-21 \mathrm{ft}$, b) enlargement of an area of (a), c) enlargerment of an area of (b) showing the "wrinkled" or layered surface of spheres, d) rounded FeS precipitates from the shallow Fan 1 at $17-18 \mathrm{ft}$. 

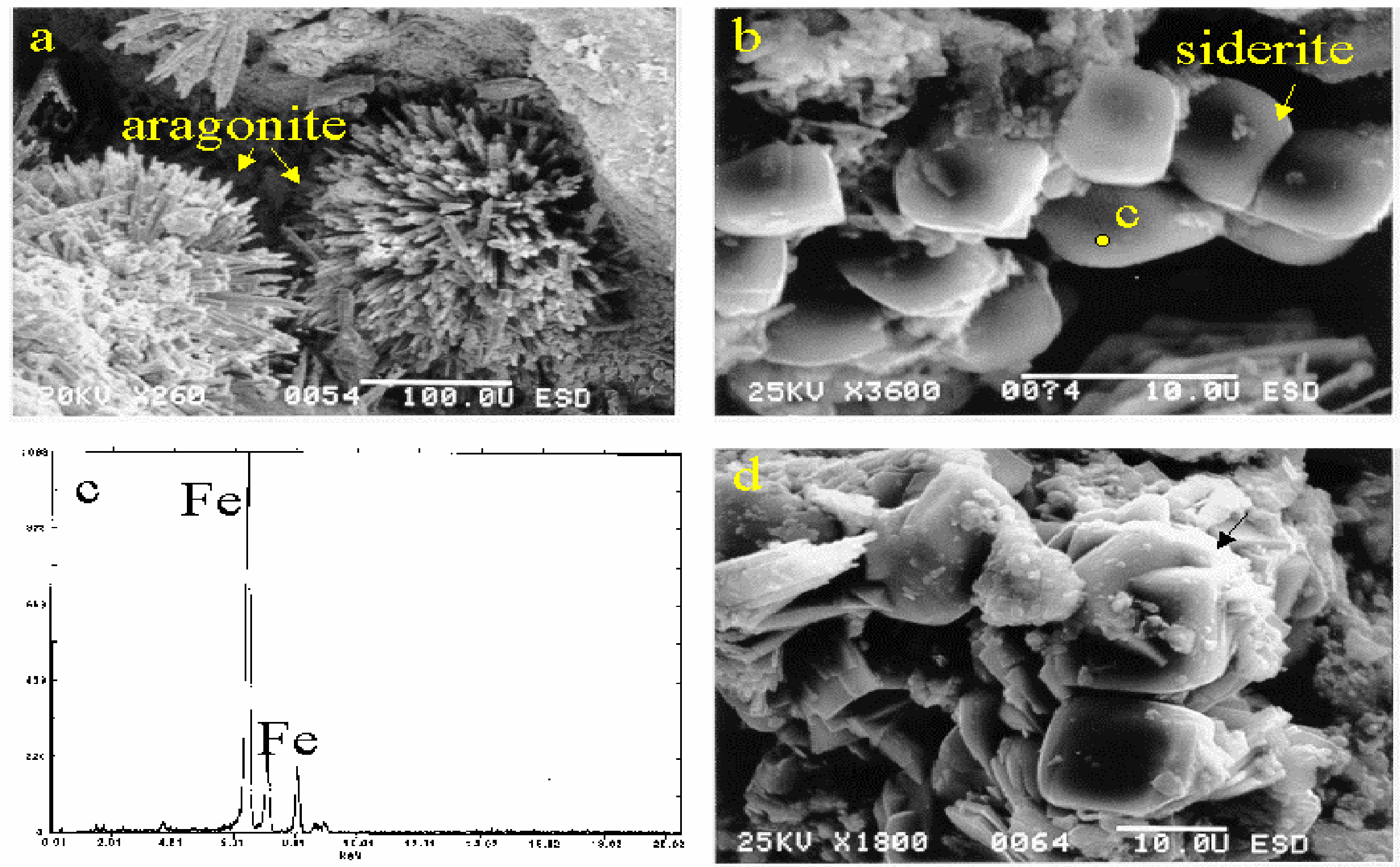

Fig. 6.14 Carbonate minerals in the barrier. a) characteristic aragonite (CaCO) crystals in the shallow Fan 1 at $19-20 \mathrm{ft}$., b) cubed shaped siderite $\left(\mathrm{FeCO}_{3}\right)$ in the shallow Fan 2 ceme ned zone up-gradient inte rface, c) SEM-EDX of an area of the siderite in (b), c) more siderite showing the characte ristic twinning struxture (arrow) in the shallow Fan 2 cemented zone up-gradient interface. 


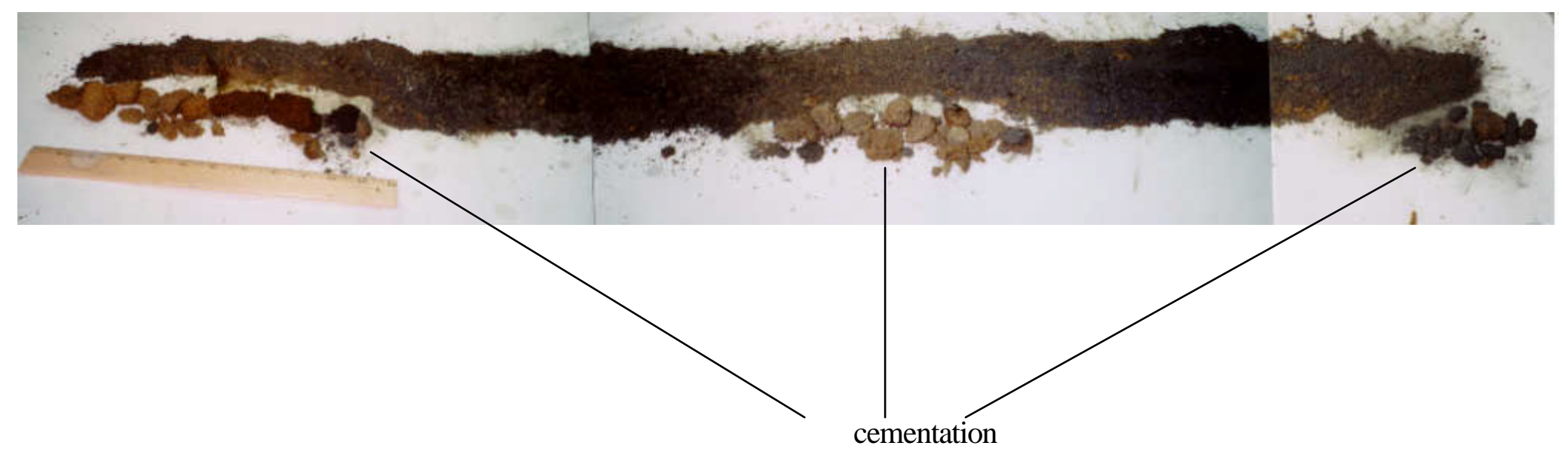

Fig. 6.15. Core material from shallow Fan 1 showing cementation. 


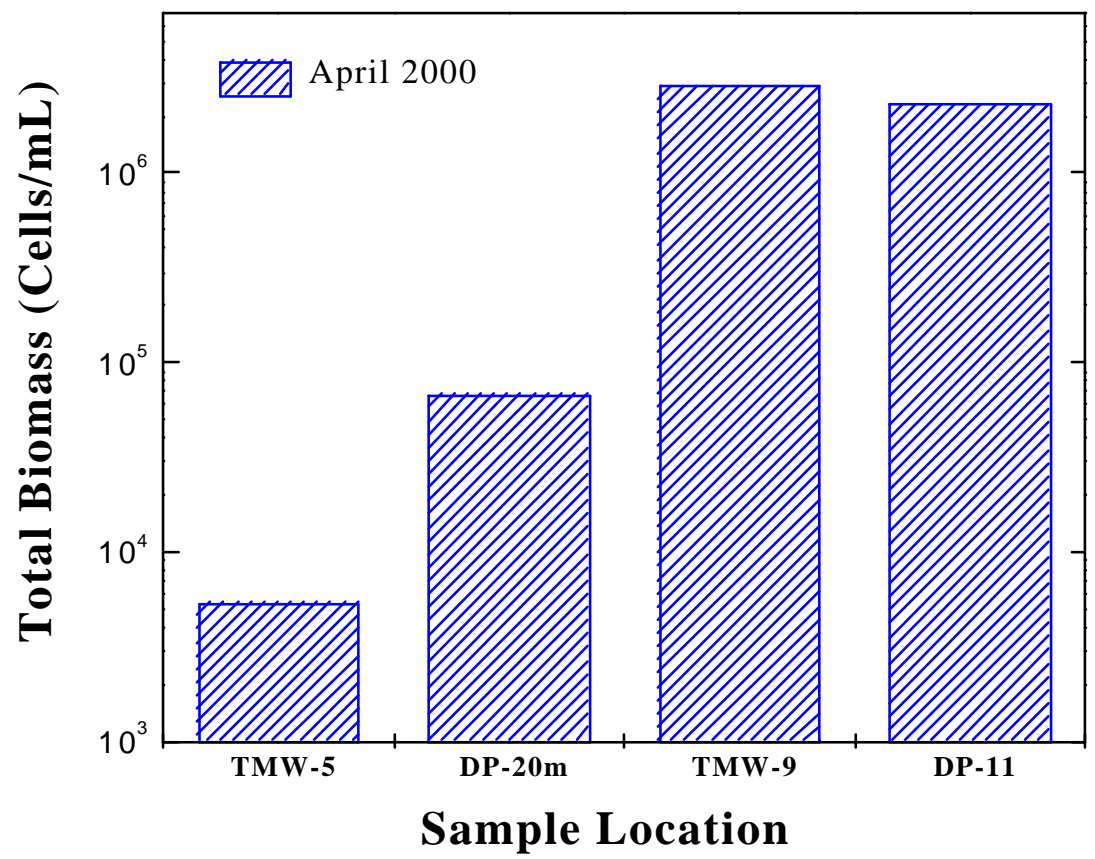

$(\mathrm{Up}=$ upgradient, $\mathrm{s}=$ shallow, Down $=$ downgradient, and $\mathrm{d}=$ deep $)$

Figure 6.16. Biomass content (picomoles PLFA/g) in groundwater samples. 


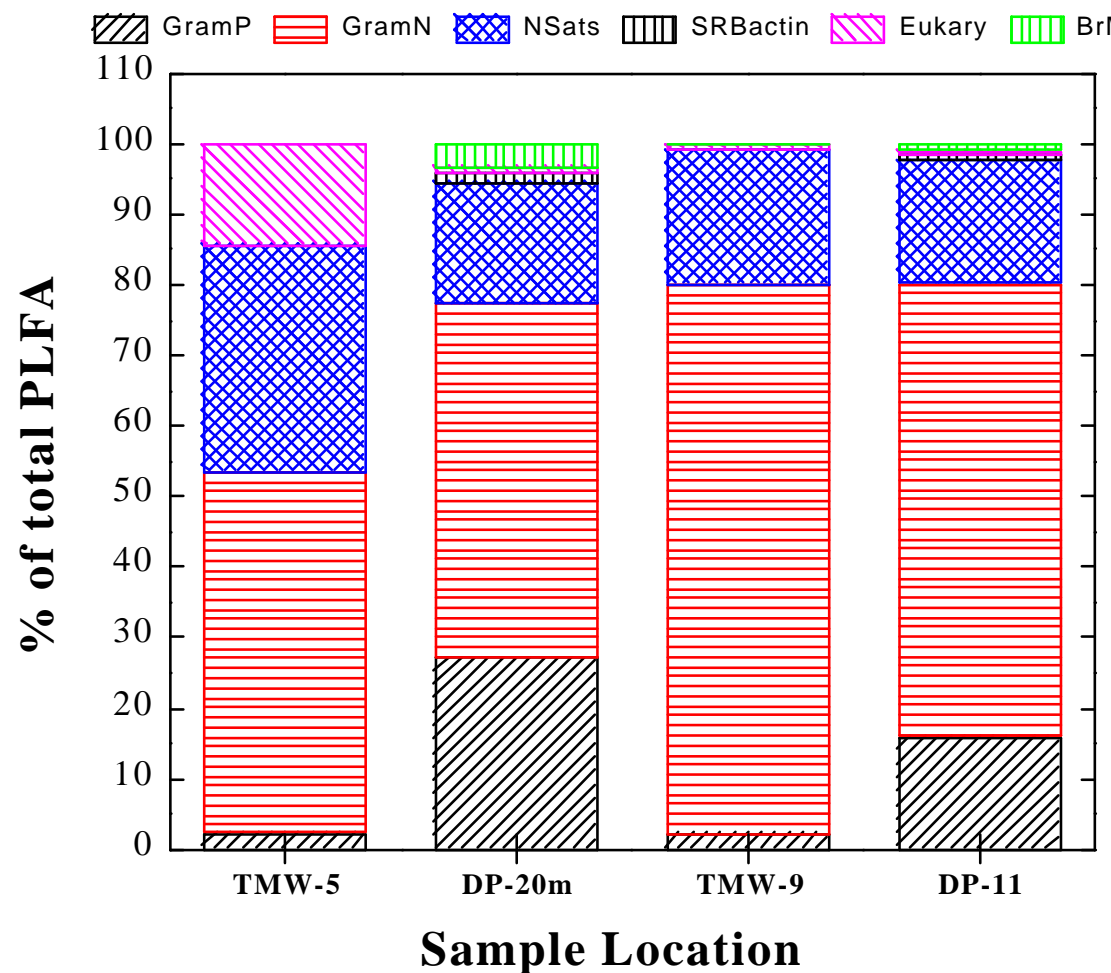

$(\mathrm{Up}=$ upgradient, $\mathrm{s}=$ shallow, Down $=$ downgradient, and $\mathrm{d}=$ deep $)$

Figure 6.17. A comparison of the relative percentages of total PLFA structural groups in groundwater samples. 


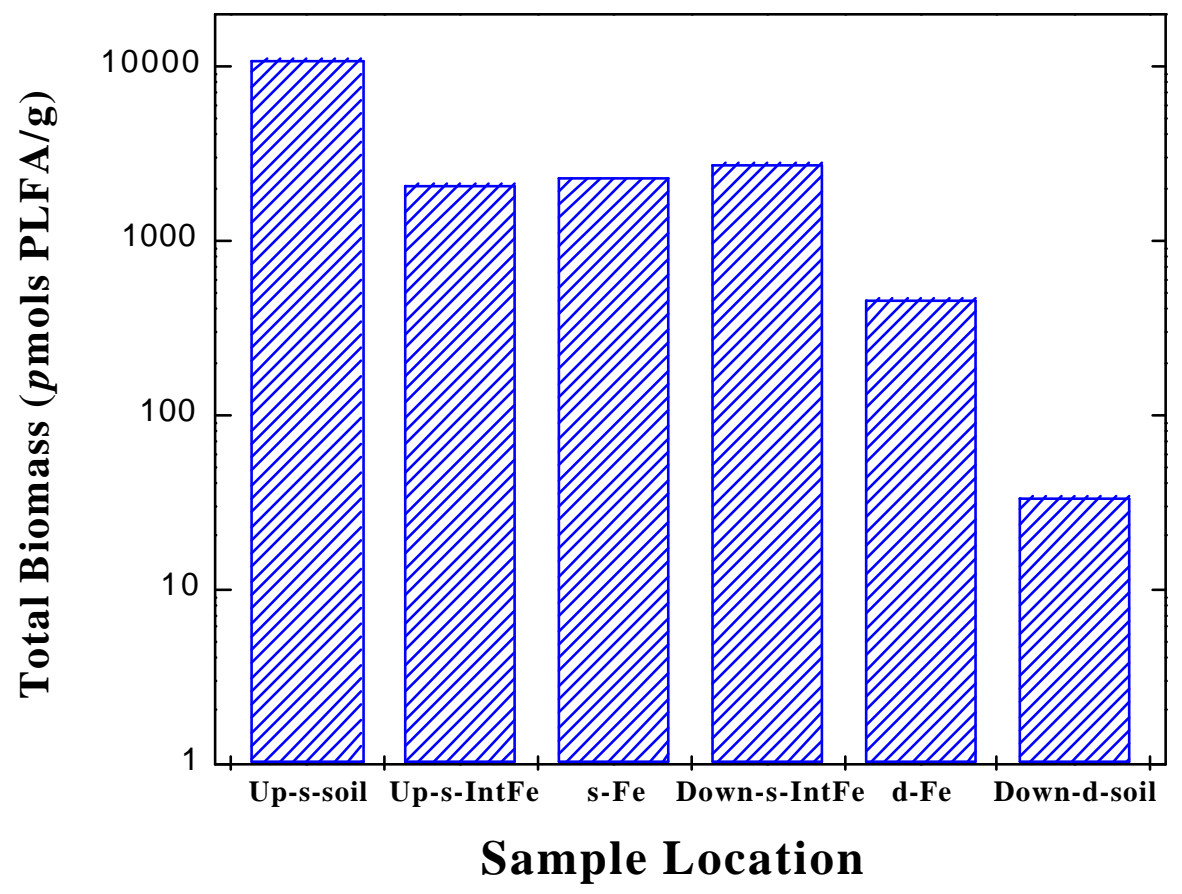

$(\mathrm{Up}=$ upgradient, $\mathrm{s}=$ shallow, Down $=$ downgradient, and $\mathrm{d}=$ deep $)$

Figure 6.18. Biomass content (picomoles PLFA/g) in soil and iron core samples. 


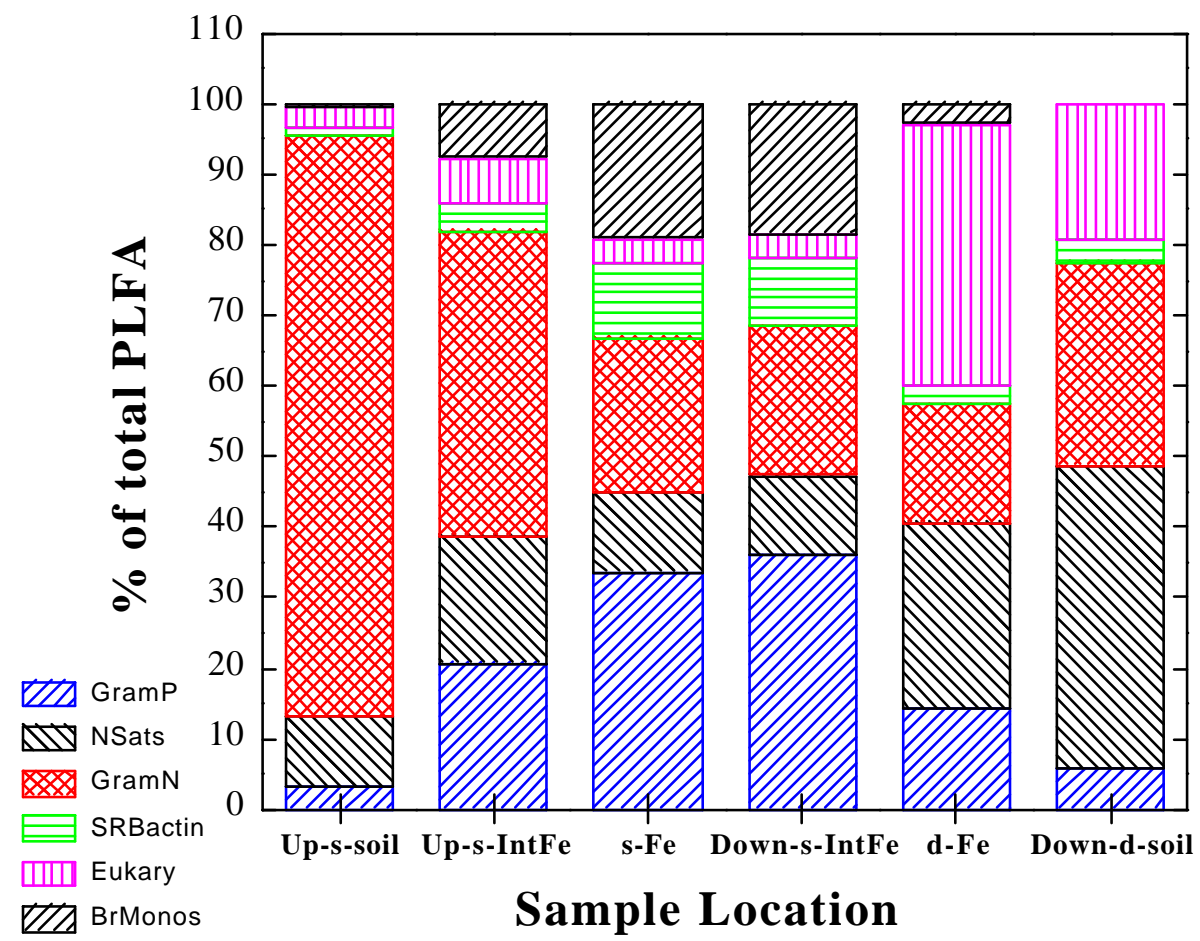

$(\mathrm{Up}=$ upgradient, $\mathrm{s}=$ shallow, Down $=$ downgradient, and $\mathrm{d}=$ deep $)$

Figure 6.19. A comparison of the relative percentages of total PLFA structural groups in the soil and iron core samples. 


\section{HYDRAULIC CONNECTIVITY}

Hydraulic gradients across the Pathway 2 barrier site have remained relatively stable and consistent from east to west (magnitude of approximately 0.02). Figures 7.1 and 7.2 show a comparison of groundwater levels and flow directions on May 6, 1998 and on May 17, 2000, respectively. These figures show that the general flow patterns at the site have not changed since the installation of the trench. Increases and decreases in the gradients across the overall site observed over the past 2.5 years appear to be primarily related to recharge during precipitation events and seasonal fluctuations.

The hydraulic gradient in the trench across the iron (figure 7.3) and within the iron (figure 7.4) has also remained consistently from east to west with an average gradient of approximately 0.008 . The distribution of ferrous iron in groundwater (figure 7.2) is also a good indicator of the direction of groundwater flow through the iron barrier. The low concentration (generally less than $10 \mathrm{mg} / \mathrm{L}$ ) ferrous iron plume shown in Figure 7.2 indicates that groundwater flows into the upgradient portion of the trench, through the iron where ferrous iron ions are released, down the downgradient portion of the trench and then exits the west end of the trench and flows south toward seeps located along Bear Creek.

The magnitude of the hydraulic gradient across the iron increases during recharge events but the direction of the groundwater flow has been consistently from east to west during the past 2.5 years. However, closer inspection of gradient fluctuations within the trench and iron seem to indicate that cementation within the iron may be starting to impact groundwater flow through the iron. Figure 7.3 shows the groundwater elevations and gradients between 3 wells located in the Pathway 2 trench. Since the spring of 1999, recharge events appear to have a more pronounced impact on the magnitudes of hydraulic gradients observed between wells located upgradient (TMW11), within (TMW9), and downgradient (TMW7) of the iron than before this time. This data suggests that the connectivity of the iron and gravel in the upgradient portion of the trench to the iron and gravel in the downgradient portion of the trench may be decreasing over time due to cementation of the iron.

Coincidentally, uranium concentrations in upgradient well TMW11 and wells DP22M, DP22S, and DP21M located the furthest upgradient but still in the iron, have an increasing trend starting in the spring of 1999. In addition, an increasing trend in nitrate concentrations in TMW11 and DP22M also appears to begin in this timeframe. These data collectively may indicate that cementation of the iron in the upgradient portion of the trench may be causing a decrease in iron reactivity and the beginning stages of hydraulic clogging. However, it should be noted that the majority of wells located further downgradient in the iron still have very low uranium and nitrate concentrations suggesting that much of the iron barrier is still quite reactive and is removing contaminants. 


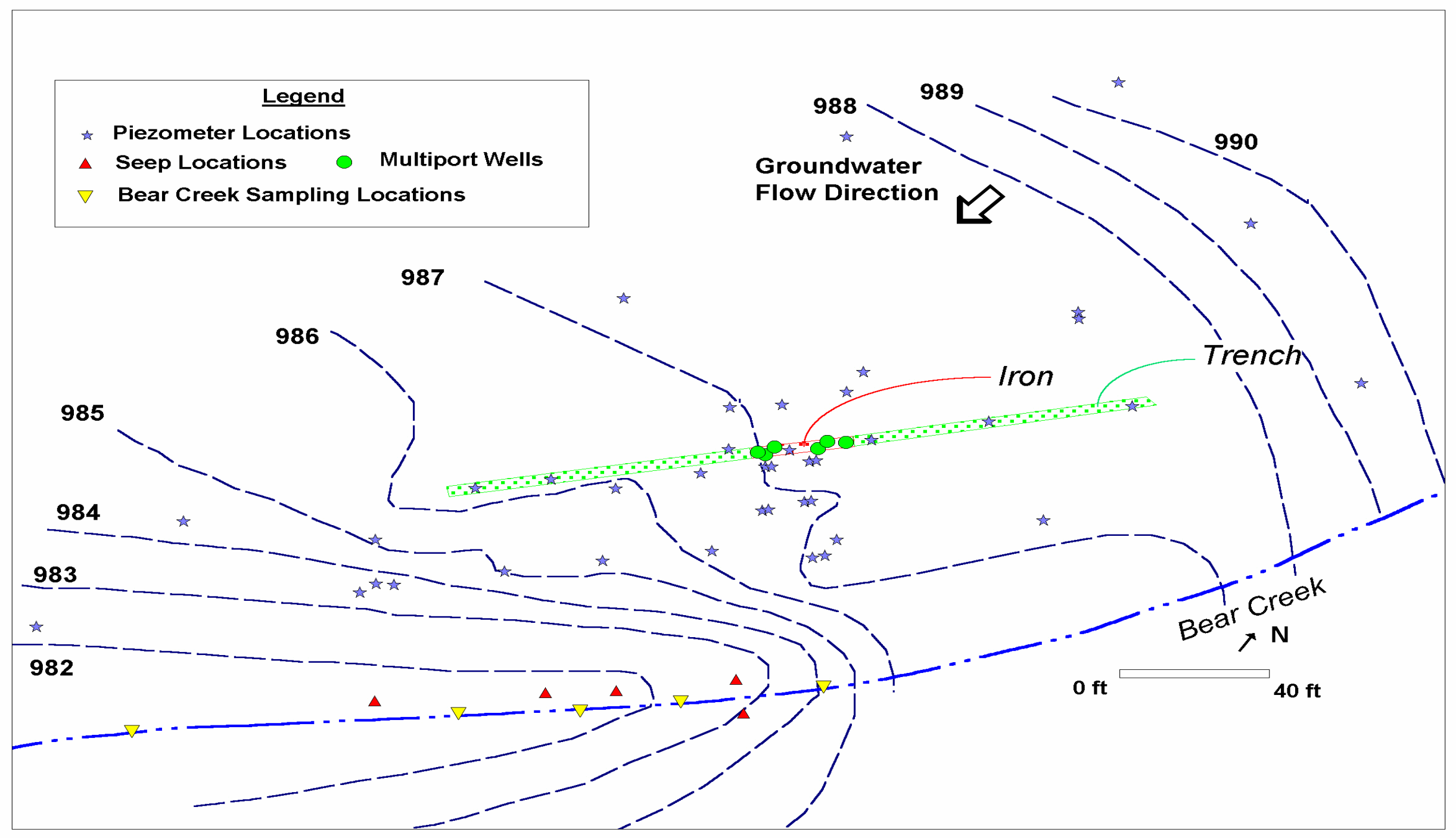

Fig 7.1. Pathway 2 Water Levels on May 6, 1998 


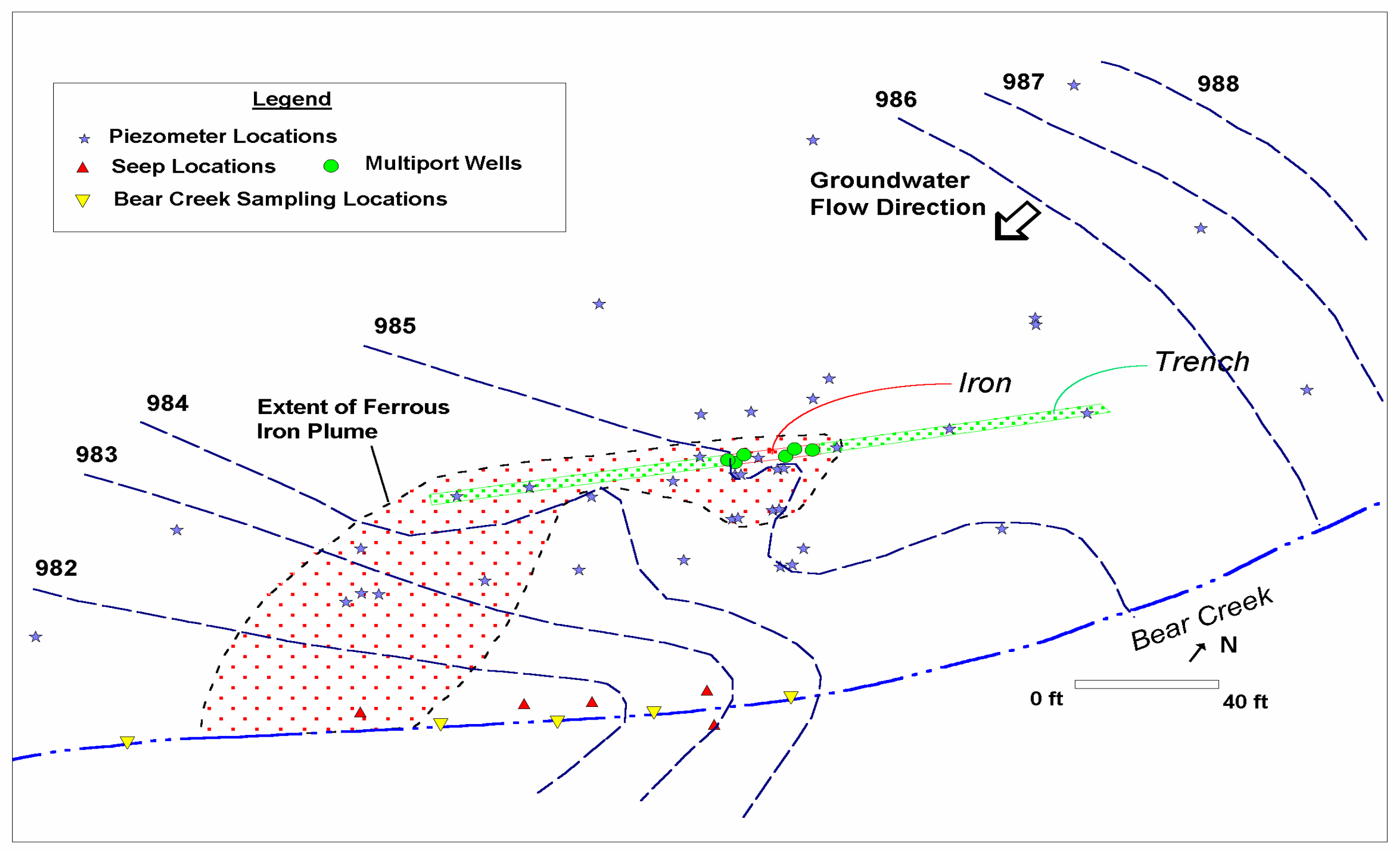


Figure 7.3 Groundwater Elevations and Gradients Across the Iron In the Pathway 2 Trench

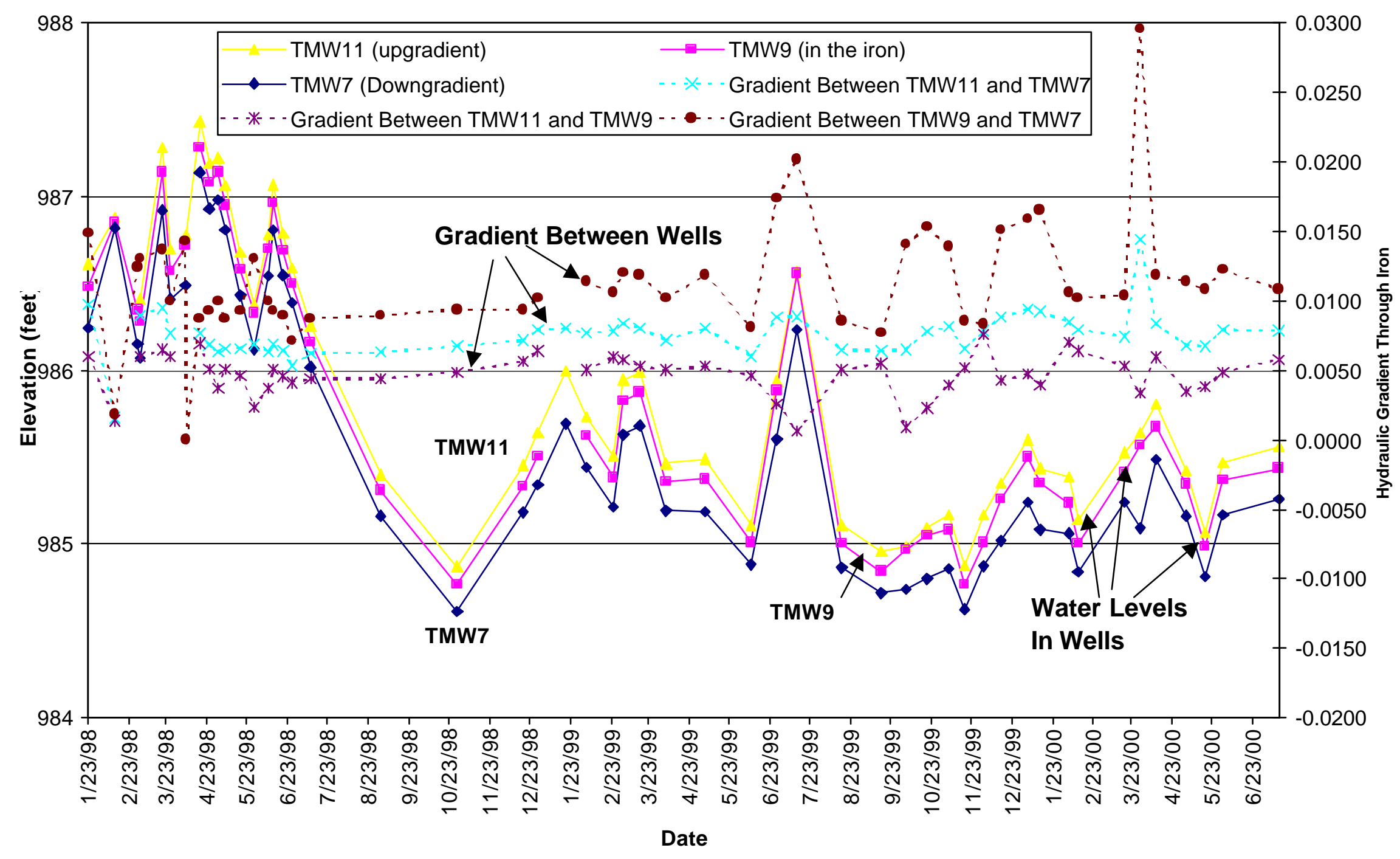


Figure 7.4 Pathway 2 Groundwater Elevations (Manual)

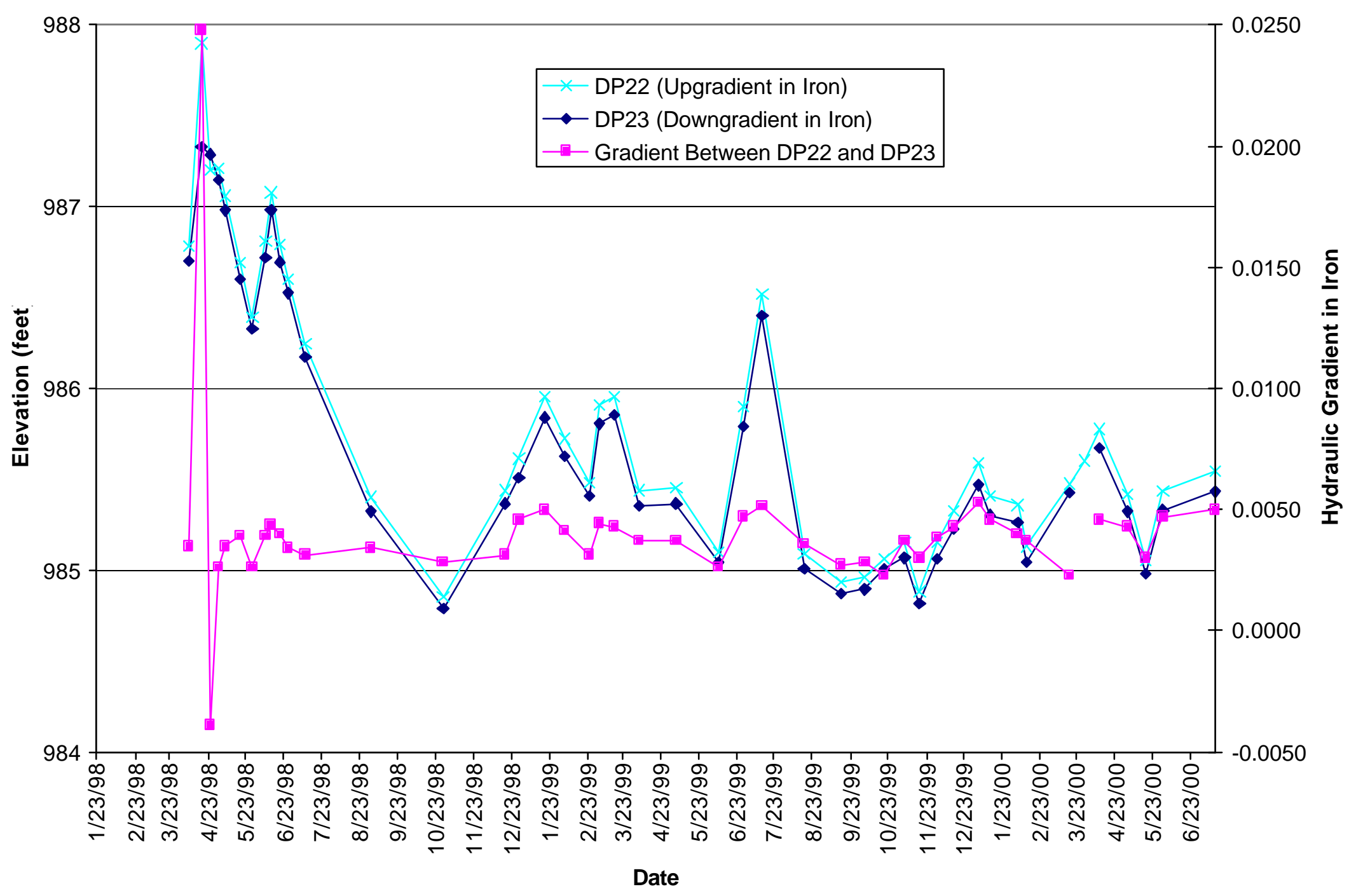




\section{REFERENCES}

Deer, W.A., R.A. Howie, and J. Zussman. 1983. An Introduction to the Rock Forming Minerals. $14^{\text {th }}$ Edition. Longman Group Limited, Harlow, Essex p. 528.

Erbs, M., H.C.B. Hansen, and C.E. Olsen. 1999. Reductive Dechlorination of Carbon Tetrachloride Using Iron (II) Iron(III) Hydroxide Sulfate (Green Rust). Environ. Sci. Technol. 33: 307-311.

Gillham, R.W., \& S.F. O'Hannesin. (1992). Metal-Catalysed Abiotic Degradation of Halogenated Organic Compounds. IAH Conference "Modern Trends In Hydrogeology". Hamilton Ontario, Canada.

Gu, B., L. Liang, M.J. Dickey, X. Yin, and S. Dai. 1998. Reductive Precipitation of Uranium (VI) by ZeroValence Iron. Environ. Sci. Technol. 32:3366-3373.

Gu, B., T.J. Phelps, L. Liang, M.J. Dickey, Y. Roh, B.L. Kinsall, A.V. Palumbo, and G.K. Jacobs. 1999. Biogeochemical Dynamics in Zero-Valent Iron Columns: Implications for Permeable Reactive Barriers. Environ. Sci. Technol. 33:2170-2177.

Jacobs EM Team, 1998. Engineering Evaluation/Cost Analysis for the Bear Creek Valley Tributary Interception Trenches for the S-3 Uranium Plume, Oak Ridge Y-12 Plant, Oak Ridge, Tennessee.

Klein, C., and C.S. Hurlbut, Jr. 1977. Manual of Mineralogy. $20^{\text {th }}$ edition. John Wiley and Sons. New York (NY) USA. 596p.

Liang, L., O.R. West, N.E. Korte, J.D. Goodlaxson, D.A. Pickering, J.L. Zutman, F.J. Anderson, C.A. Welch, M.J. Pelfrey, and M.J. Dickey. 1997. The X-625 Groundwater Treatment Facility. A FieldScale Test of Trichloroethylene Dechlorination Using Iron Filings for the X-120/X-749 Groundwater Plume. ORNL/TM-13217. Oak Ridge, TN: Oak Ridge National Laboratory.

O'Hannesin, S.F. 1993. A field demonstration of a permeable reactive wall for the in-situ abiotic degradation of halogenated aliphatic organic compounds (M.S. Dissertation ed.). University of Wateroo, Ontario.

Phillips, D.H., B. Gu, D.B. Watson, Y. Roh. (In Review) Preparation of $\mathrm{Fe}^{0}$ reactive barrier material for mineralogical analysis by $\mathrm{x}$-ray diffraction.

Phillips, D.H., B. Gu, D.B. Watson, Y. Roh, L. Liang, and S.Y. Lee. 2000. Performance evaluation of a zerovalent iron reactive barrier: mineralogical characteristics. Environ. Sci. Technol. 34: 4169-41-76.

Powell, R.M., R.W. Puls, S.K. Hightower, and D.A. Sabatini. 1995. Environ. Sci. Technol. 29:1913.

Puls, R.W., R.M. Powell, and C.J. Paul. 1995. In-situ remediation of groundwater contaminated with chromate and chlorinated solvents using zero-valent iron: a field study. The 209th National Meeting, American Chemical Society, Anaheim, CA 35:788-791.

Schwertmann, U. and R.M. Cornell. 1991. Iron Oxides in the Laboratory: Preparation and Characterization. VCH Publishers, Inc., New York, NY (USA) 137p. 
Shoemaker, S.H., J.F. Greiner, and R.W. Gillham. 1995 Permeable reactive barriers. In Assessment of barrier containment technologies (eds. Rumer, R.R. and J.K. Mitchell) U.S. Department of Energy pp. Section 11, 301-353.

Simon, L., J.-M. R. Genin and P.H. Refait. 1997. Standard free enthalpy of formation of Fe(II)-Fe(III) hydroxysulphite green rust one and its oxidation into hydroxysulphate green rust two. Corrosion Sci. 39: 1673-1685.

Watson, D., B. Gu, D.H. Phillips, and S.Y. Lee. 1999. Evaluation of permeable reactive barriers for removal of uranium and other inorganics at the Department of Energy Y-12 Plant, S-3 disposal ponds. ORNL/TM-1999/143: Oak Ridge National Laboratory, Oak Ridge, TN. 